UNIVERSIDADE DE SÃO PAULO

FACULDADE DE ECONOMIA, ADMINISTRAÇÃO E CONTABILIDADE DEPARTAMENTO DE ADMINISTRAÇÃO

PROGRAMA DE PÓS-GRADUAÇÃO EM ADMINISTRAÇÃO

A ASSOCIAÇÃO ENTRE PERCEPÇÃO DE SUCESSO NA CARREIRA

E VALORES INDIVIDUAIS

Betina Silvestri Miranda

Orientadora: Profa. Dra. Tania Casado

SÃO PAULO 
Prof. Dr. João Grandino Rodas Reitor da Universidade de São Paulo

Prof. Dr. Reinaldo Guerreiro

Diretor da Faculdade de Economia, Administração e Contabilidade

Prof. Dr. Adalberto Américo Fischmann

Chefe do Departamento de Administração

Prof. Dr. Lindolfo Galvão Albuquerque

Coordenador do Programa de Pós-Graduação em Administração 


\section{A ASSOCIAÇÃO ENTRE PERCEPÇÃO DE SUCESSO NA CARREIRA E VALORES} INDIVIDUAIS

Tese apresentada ao Departamento de Administração da Faculdade de Economia, Administração e Contabilidade da Universidade de São Paulo como requisito para a obtenção do título de Doutor em Ciências.

Orientadora: Profa. Dra. Tania Casado

Versão revisada 


\section{FICHA CATALOGRÁFICA}

Elaborada pela Seção de Processamento Técnico do SBD/FEA/USP

Miranda, Betina Silvestri

A associação entre percepção de sucesso na carreira e valores individuais / Betina Silvestri Miranda. - São Paulo, 2013.

$165 \mathrm{p}$.

Tese (Doutorado) - Universidade de São Paulo, 2013.

Orientador: Tania Casado.

1. Administração de carreiras 2. Sucesso profissional 3. Valores pessoais I. Universidade de São Paulo. Faculdade de Economia, Administração e Contabilidade. II. Título.

CDD -658.409 
À minha família -

meus maiores amores, meus melhores amigos 
Agradeço à minha orientadora, Profa. Dra. Tania Casado, pela confiança no meu potencial desde o princípio, pela compreensão, pela amizade e pelo cuidado comigo ao longo dos últimos quatro anos e pelas críticas ao meu trabalho ao final dessa jornada. Seu afeto, seus conselhos e seus ensinamentos foram valiosos para impulsionar o meu crescimento.

Agradeço a atenção que recebi dos professores e dos funcionários da Faculdade de Economia, Administração e Contabilidade (FEA/USP).

Agradeço, em especial, aos Profs. Drs. Joel de Sousa Dutra e Edson Crescitelli pelas contribuições ao estudo oferecidas no exame de qualificação.

Muito obrigada à Danilca Galdini e à Sofia Esteves por me apoiarem profissionalmente.

Agradeço ainda ao FEAmais e à Nextview People por me ajudarem na divulgação da pesquisa na etapa da coleta de dados.

A todos os participantes do estudo, por generosamente disporem de seu tempo, fornecendo os dados para que este trabalho pudesse ser concluído, meu muito obrigada.

Também agradeço aos amigos e aos colegas, com quem compartilhei as alegrias e as dificuldades ao longo desse processo, principalmente, à Jacquelaine Borges, à Angeli Kishore, à Angela Lucas, ao Eduardo de São Paulo, ao Marcus Riether, à Tatiane Corrêa e ao Eduardo Toyoda.

Agradeço ao Pedro, à Janete, à Liana e ao Augusto por estarem sempre presentes em minha vida, por me ensinarem constantemente a ser uma pessoa melhor e por terem me dado todo o amor e o apoio nos momentos mais difíceis da minha trajetória. Obrigada por serem a minha família.

Finalmente, agradeço à CAPES pelo financiamento recebido. 


\section{RESUMO}

Mudanças no cenário econômico, tecnológico e político influenciaram a construção de novas estruturas organizacionais e alterações demográficas e culturais implicaram a alteração de postura das pessoas em relação às suas carreiras. Nesse contexto, teóricos modificaram o conceito de carreira para representar as trajetórias atuais, mais idiossincráticas e autodirigidas. Nessa esteira, pontuou-se a necessidade de reavaliar o construto sucesso na carreira. Sugeriuse ainda que valores individuais influenciassem as consequências de carreira obtidas pelos indivíduos. Assim, este estudo teve o intuito de observar se existem associações entre os valores pessoais e os critérios de sucesso na carreira. Para tanto, construiu-se e validou-se um inventário de sucesso na carreira, avaliou-se sua estrutura dimensional e sua associação com os valores individuais e observou-se a proximidade dos dois construtos em um mapa perceptual. Os resultados da validação apontaram seis fatores de critérios de sucesso na carreira utilizados pelos indivíduos. $\mathrm{O}$ escalonamento multidimensional permitiu identificar duas dimensões bipolares que opõem um foco no indivíduo a um relacional e aspectos factuais aos perceptivos das consequências de carreira. As associações e as representações de proximidades entre os dois construtos sugeriram que os fatores de sucesso de carreira estão orientados aos mesmos propósitos que os valores individuais. Esta tese, assim, contribuiu para a compreensão da estrutura dimensional do sucesso na carreira e da associação desse construto com o sistema de valores individuais. 


\begin{abstract}
Peoples' perceptions concerning their own professional careers have been affected by demographic and cultural changes, at the same time as technological, economical and political changes influence the construction of new organizational structures. According to such context, researchers have proposed changes on career concepts, in order to represent modern trajectories, more idiosyncratic and self-directed fashion. Following this conceptual line, it was perceived the need to reassess the construct of career success. It was further suggested that individual values would influence the effects obtained by the individual career. Therefore, this study aimed to verify whether associations exist between personal values and criteria for career success. To this end, it was constructed and validated an inventory of career success, evaluating its dimensional structure and association with individual values and observing the proximity of the two constructs in a perceptual map. Validation results indicated six factors of career success criteria used by individuals. Multidimensional scaling identified two bipolar dimensions that oppose a focus on the individual to relational and factual aspects of the perceptual consequences of career. Proximity representations and associations between the two constructs suggested that career success factors are oriented by the same purposes as the individual values. Thus, this dissertation contributed to a better understanding of the dimensional structure of career success as a construct and its association with a system of individual values.
\end{abstract}




\section{SUMÁRIO}

LISTA DE QUADROS 3

LISTA DE TABELAS

LISTA DE GRÁFICOS

LISTA DE FIGURAS 9

1. INTRODUÇÃO 11

$\begin{array}{lll}1.1 & \text { Justificativa } & 15\end{array}$

1.2 Objetivo 16

2. SUCESSO NA CARREIRA 17

2.1 Carreiras: um breve histórico $\quad 17$

2.2 Dimensões das carreiras 23

$\begin{array}{lll}2.3 & \text { Sucesso na carreira } & 29\end{array}$

3. VALORES INDIVIDUAIS 44

3.1 Valores individuais: conceito e estrutura 44

3.2 Valores individuais: relações com variáveis individuais e contextuais 53

4. SUCESSO NA CARREIRA E VALORES INDIVIDUAIS 63

5. A METODOLOGIA 70

5.1 Variáveis do modelo conceitual de sucesso na carreira e valores pessoais $\quad 70$

$\begin{array}{lll}5.2 & \text { Tipo de estudo } & 73\end{array}$

$\begin{array}{lll}5.3 & \text { População e amostra do estudo } & 75\end{array}$

$\begin{array}{lll}5.4 & \text { Coleta de dados e instrumentos } & 76\end{array}$

5.4.1 Estudo 1: construção e validação do inventário de sucesso na carreira 77

5.4.2 Estudo 2: verificação da relação entre sucesso na carreira e valores pessoais 95

5.5 Técnicas selecionadas para a análise de dados 97

6. OS RESULTADOS 101

6.1 Caracterização da amostra 101

6.2 Observação da estrutura dimensional dos valores individuais 106

6.3 Verificação da estrutura dimensional dos critérios de sucesso na carreira 109

6.4 Averiguação da associação e da proximidade entre valores pessoais e critérios $\begin{array}{ll}\text { de sucesso na carreira } & 116\end{array}$

7. CONSIDERAÇÕES FINAIS 126

$\begin{array}{lll}7.1 & \text { Implicações para a prática } & 131\end{array}$

7.2 Limitações do estudo e implicações para futuras pesquisas 132

$\begin{array}{ll}\text { REFERÊNCIAS } & 135\end{array}$

$\begin{array}{ll}\text { ANEXOS } & 147\end{array}$ 


\section{LISTA DE QUADROS}

Quadro 1 - Os significados de sucesso na carreira. 35

Quadro 2 - Os dez domínios motivacionais dos valores.

Quadro 3 - Dimensões constitutivas da estrutura do sistema de valores e de critérios de avaliação do sucesso na carreira.

Quadro 4 - Definições dos critérios de avaliação do sucesso na carreira.

Quadro 5 - Critérios para a avaliação do sucesso na carreira. $\quad 82$

Quadro 6 - Fatores e número de itens do inventário de sucesso na carreira. 96

Quadro 7 - Técnicas estatísticas aplicadas. 


\section{LISTA DE TABELAS}

Tabela 1 - Caracterização da amostra para validação do inventário de sucesso na carreira. 88 Tabela 2 - Fatores, comunalidades, eigenvalues, variância explicada e alfa de Cronbach do inventário de sucesso na carreira.

Tabela 3 - Caracterização da amostra do estudo.

Tabela 4 - Índices de adequação do mapa perceptual dos domínios de valores individuais. 107

Tabela 5 - Índices de adequação do mapa perceptual dos critérios de sucesso na carreira. 111

Tabela 6 - Associações entre domínios de valores individuais e critérios de sucesso na carreira.

Tabela 7 - Índices de adequação do mapa perceptual dos domínios de valores e dos critérios de sucesso na carreira. 


\section{LISTA DE GRÁFICOS}

Gráfico 1 - Gráfico scree do inventário de sucesso na carreira.

Gráfico 2 - Mapa perceptual dos domínios de valores individuais.

Gráfico 3 - Mapa perceptual dos critérios de sucesso na carreira.

Gráfico 4 - Mapa perceptual dos domínios de valores individuais e dos critérios de sucesso na carreira. 


\section{LISTA DE FIGURAS}

Figura 1 - Interrelações dos aspectos da carreira dos indivíduos.

Figura 2 - Estrutura do sistema de valores.

Figura 3 - Sobreposição da estrutura do sistema de valores e de critérios de avaliação do sucesso na carreira.

Figura 4 - Estrutura do sistema de valores.

Figura 5 - Sobreposição da estrutura do sistema de valores e de critérios de avaliação do sucesso na carreira. 


\section{INTRODUÇÃO}

Mudanças sociais, econômicas e políticas, tais como a globalização, a inovação tecnológica, o acirramento da competição internacional, a diversificação da força de trabalho, dentre outras (KANTER, 1989; STOREY, 2000), influenciaram a construção de um novo cenário nas organizações de trabalho, caracterizado pelo achatamento de suas estruturas, pelos downsizings corporativos e por uma maior utilização da mão de obra terceirizada e de consultores externos (HALL; MIRVIS, 1996).

Um dos impactos resultantes foi o enfraquecimento do que antes havia sido considerado um sistema estável e relativamente linear de planejamento e de desenvolvimento da carreira dos empregados: um sistema conduzido pela organização e não pelo indivíduo.

Kanter (1989) afirma que o padrão tradicional de carreira foi desafiado em sua lógica: não há mais a possibilidade de um contínuo crescimento organizacional, de forma que oportunidades de ascensão na carreira possam ser oferecidas por meio da expansão da largura da pirâmide hierárquica, bem como não pode mais ser mantida pelos empregadores a promessa da estabilidade no emprego, o que dificulta a aceitação, por parte dos empregados, da postergação do recebimento de recompensas para quando se alcançam cargos de níveis mais elevados.

Por outro lado, mudanças demográficas e culturais levaram as pessoas a alterarem os seus comportamentos e as suas atitudes em relação à carreira (STOREY, 2000; SULLIVAN; BARUCH, 2009). A entrada das mulheres na força de trabalho e o surgimento de novas estruturas familiares e de casais de carreira dual impulsionaram o reconhecimento da importância dos diversos domínios da vida para a satisfação das pessoas com as suas carreiras, especialmente, por meio do equilíbrio entre demandas e responsabilidades dos papeis de dentro e de fora do ambiente de trabalho (GREENHAUS; FOLEY, 2007; GUEST; STURGES, 2007).

O aumento da expectativa de vida, com a consequente ampliação da vida laboral, permitiu que indivíduos questionassem os objetivos traçados no começo de suas carreiras, adquirissem novos conhecimentos e desenvolvessem novas habilidades para, então, mudarem suas 
trajetórias de carreira, engajando-se em papeis de trabalho completamente diferentes dos anteriores a fim de satisfazerem os seus novos desejos (SULLIVAN; BARUCH, 2009).

Além disso, há uma maior ênfase para a necessidade de que as carreiras proporcionem tarefas que tenham um maior significado, refletindo os propósitos de vida dos indivíduos que desejam contribuir para um mundo melhor (WRZESNIEWSKI, 2002).

Hall (2002) explica que a nova carreira está sendo gerida pelo indivíduo e não mais por uma organização, e que a força motriz dessa transformação são as necessidades, os valores e o desejo por sucesso psicológico - em oposição ao sucesso definido externamente ao indivíduo.

A observação de Hall é corroborada pela análise de Inglehart e Welzel (2005) sobre a mudança de valores que decorreu do aumento do desenvolvimento socioeconômico da era industrial para a sociedade da informação. Segundo os autores, os valores mais salientados passaram do secular-racional, sustentado pela lógica da melhoria do bem estar humano por meio da produção de bens materiais na era industrial, para os valores de auto-expressão, apoiados pela lógica do aumento do bem estar humano por meio de seu estilo de vida na sociedade da informação.

Assim, a pós-industrialização, ao trazer condições de existência ainda mais favoráveis do que a industrialização, tornou as pessoas economicamente mais seguras, intelectualmente mais autônomas e socialmente mais independentes (INGLEHART; WELZEL, 2005). Com isso, os autores salientam que a ênfase cultural se alterou da disciplina coletiva para a liberdade individual, da conformidade ao grupo para a diversidade humana e do estado de autoridade para a autonomia individual.

Esse processo emancipador torna as pessoas menos inclinadas a aceitar autoridade e verdades dogmáticas e faz com que priorizem a liberdade de escolha em todos os principais domínios da vida, ajudando a reformular papeis de gênero, motivações para o trabalho, atividades comunitárias, participação política, valores familiares e religiosidade (INGLEHART; WELZEL, 2005).

Sendo assim, fica evidente que tanto o contexto quanto as pessoas provocaram mudanças nos padrões de carreira ou, ao menos, na forma como atualmente se entende o que é carreira. A 
definição de carreira tradicional, a qual está intimamente ligada à estrutura hierárquica da organização deixou de contemplar uma boa parte das trajetórias de carreira atuais (ARTHUR; ROUSSEAU, 1996; HESLIN, 2005; SULLIVAN, 1999).

Arthur et al (1989) propuseram que o conceito de carreira fosse mais abrangente para abarcar as idiossincrasias das novas carreiras. $\mathrm{O}$ foco anterior do conceito de carreira estava centrado na organização; era ela quem definia os movimentos entre posições e ofícios das pessoas. No conceito atual, o foco incide sobre o indivíduo, visto como desenvolvedor e gestor de sua própria carreira.

Da mesma forma que tais mudanças tiveram impacto sobre a postura profissional dos indivíduos, elas também estão influenciando a forma como eles avaliam o seu próprio sucesso na carreira, uma vez que construir uma trajetória de carreira ascendente dentro de uma só organização durante a vida parece não ser mais provável, e nem desejável, para todos.

Sucesso tem sua origem na palavra latina: succedere, que significa, o que se sucede ou o que se segue. Em outras palavras, é uma consequência sem um valor definido. Sucesso, assim entendido, pode ser bom ou mau. Culturalmente, contudo, desde o século XVI, sucesso é uma palavra utilizada com uma conotação positiva (GUNZ; HESLIN, 2005). Seu antônimo seria fracasso. Sucesso é uma consequência boa, portanto. A contrário senso, fracasso, uma consequência ruim.

Tradicionalmente, a pesquisa sobre sucesso na carreira tem utilizado, principalmente, critérios objetivos, tais como os aumentos salariais, a posição ocupada pelos indivíduos na hierarquia organizacional e o número de promoções que receberam em sua vida laboral (ARTHUR et al, 2005; HESLIN, 2005).

O sucesso subjetivo na carreira, por sua vez, tem sido mensurado por meio de escalas de satisfação com o trabalho, com a carreira ou com a vida (GREENHAUS, 2003; HESLIN, 2005). No entanto, pesquisas qualitativas mais recentes evidenciam uma diversidade de temas mencionados pelos indivíduos sobre o que ter sucesso na carreira significa.

Tais temas encampam desde os critérios objetivos característicos da carreira tradicional, como, por exemplo, recompensas financeiras e avanço na hierarquia organizacional, até os mais 
subjetivos, tais como integridade, realização pessoal e liberdade de escolha (e.g., DEMEL et al, 2012; DYKE; MURPHY, 2006; HENNEQUIN, 2007; STURGES, 1999).

Isto evidencia a limitação de se avaliar o sucesso subjetivo apenas por meio de escalas de satisfação geral com o trabalho, com a carreira ou com a vida (ARTHUR et al, 2005). Assim, Arthur et al (2005), Greenhaus (2003) e Heslin (2005) afirmam que as pesquisas sobre sucesso na carreira devem incorporar outros indicadores, uma vez que entendem que este é um fenômeno multidimensional.

Além disso, Gunz et al (2007) e Patton (2000) apontam que valores afetam significativamente as decisões de carreira, pois as pessoas costumam escolher organizações, ocupações e trajetórias que estão de acordo com seus valores. Para tais autores, os valores também são potencialmente capazes de gerar ou orientar a escolha dos critérios pelos quais as pessoas aferem se estão alcançando o sucesso em suas carreiras.

Como salientam Mainiero e Sullivan (2006), as pessoas avaliam o sucesso de formas diferentes. Quem emite um juízo sobre o que é bom ou mau, decide com base em algum sistema valorativo. Positivo e negativo, afinal, são julgamentos de valor.

Valores representam objetivos desejáveis transituacionais, que variam em importância e servem como princípios orientadores da vida de uma pessoa (SCHWARTZ, 1994) e atribui-se a eles a capacidade de predizer atitudes e comportamentos (ROHAN, 2000). Conforme Kuczinski e Navara (2006), os valores estão presentes sempre que é necessário julgar quais as ações, os pensamentos e os sentimentos são mais úteis, importantes ou desejáveis em um determinado contexto.

Assim, parece plausível que os critérios de sucesso na carreira pelos quais as pessoas avaliam se as consequências de suas trajetórias foram positivas ou não estejam relacionados aos seus sistemas de valores. É dentro desta proposta de se compreender as dimensões do sucesso na carreira e de suas associações com os sistemas de valores pessoais que este estudo se insere.

Logo, a pergunta de pesquisa a qual se pretende responder neste trabalho é: existe correlação entre os valores individuais e os critérios, subjetivos e objetivos, que as pessoas utilizam para avaliar o seu próprio sucesso na carreira? 


\subsection{Justificativa}

No presente estudo, foram encontradas poucas pesquisas que, de alguma forma, relacionavam sistemas de valores individuais e sucesso na carreira. Em uma investigação com 399 trabalhadores de Singapura, Choo et al (2009) apuraram que diferenças de valores pessoais e laborais impactavam a satisfação com o trabalho.

Orpen (1976), em uma investigação com 92 gestores sul africanos, encontrou que indivíduos os quais enfatizavam valores de produtividade, lucratividade, agressividade, sucesso, mudança e competição recebiam maiores salários do que aqueles que priorizavam valores de bem estar social, dignidade, honra, religião, segurança, lazer e confiança.

Por fim, a partir de um estudo com pequenos empreendedores, Gorgiewski et al (2011) concluíram que os valores pessoais influenciavam a escolha dos critérios com os quais eles avaliavam o sucesso de seus próprios negócios.

Embora tais estudos associem os valores individuais aos critérios de sucesso na carreira, não consideram a multidimensionalidade do segundo construto. O primeiro, de Choo et al (2009) reconhece tal relação apenas no que tange ao sucesso subjetivo. O segundo, de Orpen (1976), considera apenas o sucesso objetivo. Gorgiewski et al (2009) foram os únicos a analisar a associação entre valores de empresários e sucesso subjetivo e objetivo. Contudo, o sucesso foi avaliado em relação ao empreendimento e não à própria carreira dos pesquisados.

Portanto, a proposição de Arthur et al (2005), Greenhaus (2003) e Heslin (2005) sobre a multidimensionalidade do construto sucesso na carreira ainda carece de mais evidências empíricas; enquanto a sugestão de Gunz et al (2007) e Patton (2000) sobre a associação entre este construto e valores pessoais ainda não foi investigada.

Como salientam Choo et al (2009), ao se obter um entendimento mais amplo das prioridades dos sistemas de valores dos empregados, uma organização pode formular melhores políticas de retenção, tais como treinamento e desenvolvimento, compensação e planejamento de carreira, bem como atrair e selecionar pessoas que se satisfarão com seu sistema de gestão de pessoas e que, portanto, sentir-se-ão bem sucedidas. 
Facilitar o sentimento de sucesso na carreira dos empregados, como nota Hennequin (2007), é essencial, haja vista que quando alcançado em um dado ambiente corporativo, podem-se esperar atitudes e comportamentos no trabalho mais favoráveis à empresa do que desfavoráveis. Destarte, o sucesso pessoal, afirma a autora, pode contribuir para o sucesso organizacional.

Peluchette (1993) salienta que indivíduos que não se sentem bem sucedidos estão sujeitos a sentimentos de alienação e desengajamento e que tais sentimentos afetam negativamente o desempenho em suas atividades de trabalho.

\subsection{Objetivo}

A fim de se responder o problema de pesquisa referente à existência ou à inexistência de uma associação entre o sistema de valores individuais e os critérios, subjetivos e objetivos, que as pessoas selecionam para avaliar o sucesso na carreira, o presente estudo buscará atingir o seguinte objetivo:

Averiguar se os valores individuais e os critérios, objetivos e subjetivos, que as pessoas usam para verificar seu próprio sucesso na carreira estão relacionados. 


\section{SUCESSO NA CARREIRA}

O estudo das carreiras como campo de conhecimento tem o início de sua estruturação na década de 1970, mas a existência das trajetórias de carreira é bastante anterior a essa época (MOORE et al, 2007). Carreiras se localizam no ponto onde há um encontro entre as biografias dos indivíduos e a história da sociedade e, portanto, "carreiras são sempre carreiras em contexto." (MAYRHOFER et al, 2007, p. 215)

\subsection{Carreiras: um breve histórico}

Há muitos séculos o homem "trabalha" para viver. Inicialmente, caçando, coletando e forjando instrumentos para aumentar as chances de obtenção de alimento e de proteção da sua vida e da daqueles com quem conviviam, rumando constantemente para onde houvesse maiores oportunidades de sobrevivência.

Posteriormente, passou a se fixar em locais nos quais a natureza fosse favorável à criação de animais e à agricultura, formando vilas que, no entanto, eram poucas e continham uma pequena parte da população mundial (MASSEY, 2002).

Para Massey (2002), com a fundação das vilas, pela primeira vez, os homens puderam ter um excedente de alimento às necessidades de um dia e, com isso, surgiu a primeira classe de pessoas que não precisava produzi-lo para sua própria sobrevivência, dando origem a ocupações, tais como, especialistas que criavam novas ferramentas, comerciantes que obtinham matérias-primas, artesãos produtores de bens materiais e combatentes protetores das vilas. Além disso, estruturaram-se uma elite política e uma elite religiosa.

Contudo, as forças da natureza que possibilitavam ou impediam a produção dos alimentos eram vagamente compreendidas e não controláveis e, por isso, eram atribuídas à vontade dos deuses, fortalecendo os valores tradicionais religiosos e míticos, bem como os valores de sobrevivência ${ }^{2}$ (INGLEHART; WELZEL, 2005).

\footnotetext{
1 "Careers are always careers in context."

2 Ronald Inglehart é um cientista político norte-americano, pesquisador da Universidade de Michigan e diretor do World Values Survey. Seu modelo de valores compreende que mudanças econômicas e tecnológicas estão relacionadas a variações culturais em duas dimensões: (1) valores tradicionais versus valores racionais-seculares, que contrastam, principalmente, a fé religiosa à ênfase nos modelos burocrático e científico de pensamento e (2)
} 
Savickas $(2000 ; 2007)$ aponta que a instituição social central nessas sociedades era a família e as pessoas herdavam a ocupação de seus pais, com os quais aprendiam o ofício. Eventualmente, algum dos familiares recebia um chamado vocacional para a igreja, para o serviço público ou para o comércio. A identidade social e ocupacional dos indivíduos, portanto, estava ligada ao núcleo familiar de origem.

Nos séculos que precederam o ano de 1800, a proporção de pessoas que vivia em vilas nunca excedeu a $5 \%$ e, antes disso, somente sessenta e cinco cidades em toda a história do mundo haviam alcançado populações superiores a cem mil habitantes (MASSEY, 2002).

O autor relata que por volta do século XIX, começou a troca das fontes de energias muscular e animal pelas inanimadas (e.g., energia a carvão, a vapor, eólica e hidráulica), o que possibilitou a produção em massa realizada dentro de grandes organizações de trabalho situadas nas áreas urbanas. Assim, uma grande parte da população migrou das áreas rurais para as urbanas.

Os trabalhadores das pequenas vilas e das fazendas, ao chegarem às cidades e se depararem com essas grandes empresas, perceberam que seus filhos poderiam trabalhar para um empregador, ao invés de no negócio familiar (SAVICKAS, 2000; 2007). Assim, os jovens começaram a escolher as suas próprias ocupações e não mais herdá-las; muitos deles optando por entrarem nos quadros funcionais das firmas de produção de bens que, como apontam Sullivan e Baruch (2009), trocavam a lealdade do trabalhador pela promessa implícita de um emprego assegurado ao longo de toda a vida.

Destarte, para aqueles que se tornavam gestores ou empregados, as carreiras eram definidas dentro do âmbito da empresa e envolviam movimentos ascendentes na pirâmide corporativa, na medida em que os indivíduos desenvolviam habilidades e as colocavam em prática para o sucesso profissional e da organização. Ao longo dos séculos XIX e XX, as carreiras das pessoas foram geridas pelas organizações, "uma vez que a ascensão na carreira em uma única organização era a forma mais comum de se chegar a maiores posições" (SCALABRIN et al, 2010, p. 198).

valores de sobrevivência versus valores de auto-expressão, que opõem, especialmente, a prioridade à segurança econômica e física às preocupações com o bem estar subjetivo. 
A carreira tradicional era sinônimo de carreira organizacional: uma trajetória ascendente na estrutura hierárquica formal de uma organização (ARTHUR; ROUSSEAU, 1996; GUEST; STURGES, 2007; HALL, 1996; 2002; SULLIVAN; 1999). A identidade profissional, portanto, teve seu foco reposicionado da família de origem para o trabalho desempenhado dentro da empresa (SAVICKAS, 2000); as pessoas só tinham importância dentro das estruturas das firmas (ARTHUR; ROUSSEAU, 1996).

Ademais, Inglehart e Welzel (2005) afirmam que com o controle da produtividade propiciada pelas indústrias e a partir da descoberta dos germes e dos antibióticos não era mais necessário orar para os deuses. Como a ciência e a tecnologia propiciavam aos homens o controle sobre seu ambiente, os valores religiosos tradicionais foram substituídos por valores racionaisseculares.

A globalização e o rápido avanço tecnológico, na transição do século XX para o século XXI, exigiram que as grandes companhias de praticamente todos os setores de atividade produtiva e econômica repensassem as suas estruturas organizacionais e os seus sistemas de gestão de pessoas (GUEST; STURGES, 2007; SULLIVAN, 1999; SULLIVAN; BARUCH, 2009). Tais mudanças de contexto resultaram, assim, no início do declínio da carreira tradicional para toda a vida dentro das grandes organizações (MILES; SNOW, 1996).

As empresas concorrentes estavam cortando custos e respondendo rapidamente às novas necessidades do mercado. As organizações perceberam que, diferentemente dos tempos idos, nos quais era preciso que todo o processo fosse feito internamente, era necessário que só se fizesse aquilo que se sabia fazer melhor. Assim, operações não centrais da produção foram terceirizadas para firmas especializadas e, na metade dos anos 1980, as grandes corporações passaram por processos de downsizing para ganharem flexibilidade e agilidade a fim de competir no mercado (MILES; SNOW, 1996; STOREY, 2000; SULLIVAN, 1999).

Neste contexto, surgiu uma nova forma organizacional, estruturada em redes, com empresas à jusante e à montante interligadas por meio de processos just in time (MILES; SNOW, 1996). A estabilidade no emprego, percebida pelas pessoas, esvaneceu-se à medida que as firmas se voltaram ao seu negócio central eliminando departamentos inteiros de suas estruturas (MILES; SNOW, 1996), bem como quando as empresas estatais foram privatizadas (STOREY, 2000). 
Muitos foram demitidos, sem perspectivas de encontrar um novo emprego, e os sobreviventes às reestruturações organizacionais tiveram as suas responsabilidades e as horas de trabalho aumentadas e as suas oportunidades de promoção e de estabilidade no emprego reduzidas (STOREY, 2000; SULLIVAN, 1999).

Ao mesmo tempo em que houve uma redução de oportunidades e de estabilidade nos empregos do setor industrial, a melhoria da tecnologia da informação propiciou o crescimento do setor de serviços (BELL, 1973), desenvolvendo-se atividades tais como, transporte, comércio, finanças, saúde, educação e recreação. Nessa nova ordem econômica, predominam a criação do conhecimento e as relações entre as pessoas ao invés da manufatura de bens.

Assim, alguns profissionais com perfil empreendedor fundaram as suas próprias firmas para prestarem serviços a outras na cadeia de suprimentos (MILES; SNOW, 1996). Outros se sentiram impelidos a empreender, criando trabalhos para si mesmos e buscando parceiros, fornecedores e clientes via internet (SULLIVAN; BARUCH, 2009).

Adicionalmente, a globalização e os avanços tecnológicos não trouxeram consigo apenas ameaças às carreiras dos indivíduos. As empresas que fizeram joint ventures, se fundiram, adquiriram outras ou se internacionalizaram, enfim, estabeleceram uma rede de relacionamentos global. Nesse contexto, algumas pessoas perceberam oportunidades de experiências internacionais (STOREY, 2000), de crescimento pessoal e de realização profissional dentro das empresas nas quais estavam inseridas (MILES; SNOW, 1996). Outrossim, o teletrabalho e outras formas de trabalho mais flexíveis se tornaram acessíveis para os indivíduos.

Em vez de viverem em um ambiente industrial, mecânico, cada vez mais indivíduos agora despendem suas horas produtivas lidando com pessoas, símbolos e informações (INGLEHART; WELZEL, 2005) e em uma escala global. Portanto, muitas das barreiras que limitavam a movimentação entre países e organizações e a penetração das pessoas nos mercados se dissolveram (KHAPOVA et al, 2007). Firmas passaram a ter fronteiras mais permeáveis e as carreiras se tornaram independentes das estruturas das organizações (ARTHUR et al, 2005). 
Como bem afirmam Inglehart e Welzel (2005), a alteração dos valores racionais-seculares para os valores de auto-expressão nas sociedades pós-modernas dos países com maior desenvolvimento econômico tornou a autonomia na escolha uma prioridade para os indivíduos.

Dentro deste novo cenário e em função do aumento da expectativa de vida, das novas estruturas familiares, das mudanças de valores e das necessidades de realização e de desenvolvimento, as pessoas alteraram seus comportamentos e as suas atitudes em relação à carreira (SULLIVAN; BARUCH, 2009).

Os indivíduos estão adotando uma postura mais transacional em relação aos seus empregadores, trocando desempenho por aprendizado contínuo e negociabilidade (SULLIVAN, 1999). As pessoas se tornaram mais autodirigidas em suas carreiras e em seu desenvolvimento profissional, guiando-se mais por seus próprios desejos e valores do que por práticas organizacionais de gestão de carreira (HALL, 1996; LONDON; STUMPF, 1986; SULLIVAN; BARUCH, 2009).

Diversas teorias e modelos buscaram, nos últimos anos, compreender e explicar a nova realidade do que pode se considerar uma carreira de trabalho a partir das últimas décadas do século XX e do início do século XXI. Além de se reconhecer que a carreira tradicional ainda coexista com as novas carreiras, compreende-se que há uma diversidade de formas de se estabelecer e experimentar trajetórias de carreira que não são lineares e/ou ascendentes em sua natureza.

A "carreira proteana" (HALL, 2002), por exemplo, é caracterizada pela adaptação a alterações ambientais e por frequentes mudanças, pela auto-invenção, autonomia e autodirecionamento, englobando, assim, carreiras marcadas por altos e baixos, com inícios antecipados ou tardios em relação aos padrões culturais do contexto nas quais se inserem e pelo movimento de uma linha de trabalho para outra.

Por sua vez, as carreiras sem fronteiras são aquelas que não são limitadas, nem ligadas a uma única organização, tendo uma sequência não ordenada, com menor coordenação vertical e estabilidade, sendo caracterizadas, principalmente, pela transcendência das fronteiras físicas e/ou psicológicas pelos indivíduos (ARTHUR; ROUSSEAU, 1996). 
As carreiras customizadas podem ser entendidas como aquelas distintas das normas tradicionais de carreira, tendo calendários e horas de trabalho diferenciadas, permitindo interrupções da participação na força de trabalho ou englobando relações de emprego mais dinâmicas e transacionais para satisfazer as necessidades, os valores e as preferências individuais (VALCOUR et al, 2007).

Por fim, o modelo caleidoscópico de carreiras (MAINIERO; SULLIVAN, 2006) propõe que as pessoas retificam, modificam e ajustam o rumo de suas carreiras para acomodarem as demandas e as necessidades de cada momento de suas vidas, construindo, assim, trajetórias pessoais e profissionais individualizadas.

Esses exemplos de carreiras têm em comum, além da não-linearidade, o reconhecimento de que os indivíduos estão moldando as suas trajetórias de carreira de forma que as suas experiências de trabalho e de não-trabalho atendam às suas necessidades objetivas e subjetivas ou psicológicas, acomodando as responsabilidades requeridas pelos diversos papeis que assumem nos diferentes momentos de suas vidas.

Assim sendo, a definição de carreira tradicional não contempla mais uma boa parte das biografias profissionais atuais, tendo se tornado mais abrangente, conceituada por Arthur et al (1989, p. 8) como "[...] a sequência evolutiva de experiências de trabalho vivenciadas por uma pessoa ao longo do tempo.,

Como fica evidente, o foco anterior do conceito de carreira estava centrado na organização; era ela quem definia a trajetória de carreira dos indivíduos. Também está subjacente o entendimento de que havia uma trajetória estruturada hierarquicamente pela organização e referendada socialmente pela qual os indivíduos deveriam seguir ao longo de sua vida laboral.

No conceito atual, o foco está sobre o indivíduo, visto como desenvolvedor e gestor de sua própria carreira. Nota-se ainda que a nova definição de carreira engloba tanto os movimentos entre posições, empregos, ocupações e indústrias quanto a subjetividade do indivíduo, por meio de sua interpretação sobre os eventos de trabalho e de não-trabalho, que dão

\footnotetext{
3 “[...] the evolving sequence of a person's work experiences over time."
} 
consistência à trajetória de carreira que está sendo, por ele, construída (SULLIVAN; BARUCH, 2009).

\subsection{Dimensões das carreiras}

A carreira individual é influenciada por fatores contextuais, tais como a cultura nacional, a economia e o ambiente político, e por fatores pessoais como, por exemplo, relações com outros significativos, resiliência, adaptabilidade, atitudes e valores (SULLIVAN; BARUCH, 2009).

Hughes (1997) afirma que é necessário se colocar as dimensões do indivíduo e da sociedade juntas no estudo das carreiras. Pois, pessoas são dotadas de certas habilidades e qualidades que podem ser desenvolvidas de diversas maneiras, mas também nascem em um determinado lugar e período da história e, por isso, seguem o curso de sua carreira em um arranjo social situado.

Embora as carreiras sejam passíveis de serem experimentadas apenas pelos indivíduos e sejam direcionadas por eles, por meio de suas escolhas de cursos de ação, as opções que vislumbram são limitadas ou possibilitadas pelo contexto (BARLEY, 1989).

A teoria da estruturação de Giddens (2003) procura compreender a dinâmica existente entre as oportunidades e as restrições de ação encontradas pelos indivíduos e suas escolhas de cursos de ação, propondo a existência de uma relação de interdependência entre estrutura e agência.

Agência, como conceituada pelo autor, se refere à capacidade ou poder que as pessoas têm para perpetrar eventos por meio da ação em uma base contínua. $\mathrm{O}$ agente se comporta de acordo com o que acredita que serão os resultados de sua ação; porém, nem sempre as consequências de seus atos haviam sido previamente cogitadas por ele. Assim, esses resultados inesperados se tornam as condições para as ações futuras do indivíduo.

Portanto, a ação social é processual: se desenvolve como um fluxo contínuo, cada ato se sobrepondo ao, e em parte constituindo o, ato subsequente. 
$\mathrm{O}$ autor afirma que o agente sempre tem a possibilidade de escolher agir de outra maneira; argumenta, contudo, que os indivíduos, em busca da segurança ontológica e consequente redução de sua ansiedade, invocam a rotina e o padrão na vida social, gerando uma previsibilidade dos resultados de seus atos.

A estrutura é definida por Giddens (2003) como conjuntos de regras e recursos organizados como propriedades de sistemas sociais. Estes, por sua vez, são produzidos e reproduzidos por meio das práticas sociais recursivamente aplicadas nas interações entre indivíduos.

Regras, conforme o autor, são procedimentos metodológicos generalizáveis de interação social que permitem a continuação de uma sequência estabelecida, as quais são aplicadas à produção e à reprodução das práticas sociais. Existem duas categorias de regras: as regras normativas e as regras semânticas.

As primeiras referem-se à moralidade; ou seja, aos direitos e deveres dos indivíduos em interação, bem como aos modos de conduta dos agentes, fazendo parte da estrutura de legitimação.

As segundas são concernentes à comunicação de significados; isto é, ao significado qualitativo e processual das práticas e de seu desempenho, constituindo a estrutura de significação.

Já os recursos podem ser definidos como capacidades transformadoras (GIDDENS, 2003). São classificados em dois tipos: os recursos de alocação que geram comandos sobre objetos, bens e materiais e os recursos de autoridade que geram comandos sobre outras pessoas. $\mathrm{O}$ uso do poder ou das facilidades (recursos) aos quais o agente tem acesso e que ele manipula a fim de influenciar a interação com os outros constitui-se a estrutura de dominação.

Giddens (2003) cita três formas de restrições às escolhas do agente: (1) restrições materiais, que derivam dos limites impostos pela capacidade física do corpo e pelas características do ambiente físico; (2) restrições sancionadas, que estão relacionadas ao poder e se apresentam de diversas formas, tais como a aplicação da força ou violência, ameaças ou desaprovação; e (3) restrições estruturais, que são derivadas do contexto da ação e aparecem para o agente como permissões pré-estruturadas associadas às oportunidades de ação. No entanto, as 
restrições sancionadas e estruturais só têm efeito quando o indivíduo as aquiesce ou aceita, operando por meio dos motivos e das razões do agente.

Nesse diapasão, o mencionado estudioso compreende que a estrutura provê as condições que possibilitam e restringem a ação dos indivíduos nas interações sociais. Por outro lado, as ações dos indivíduos produzem e reproduzem a estrutura. Portanto, a relação entre agência e estrutura deve ser vista como um processo dinâmico e como uma dualidade; ou seja, a estrutura é tanto o meio como o resultado da ação.

Na medida que a ação das pessoas muda, as condições que possibilitam ou restringem novas ações também se alteram, provocando transformações sociais. Pode-se, destarte, entender que a ação humana e a interação na sociedade afetam as estruturas sociais nas quais as carreiras se desenvolvem (BAILYN, 1989).

Gunz et al (2007), ao discorrerem sobre as fronteiras de carreiras, fornecem um exemplo da dinâmica entre a ação e a estrutura dentro do âmbito das carreiras. Para os autores, as carreiras são padrões de movimento pelo cenário de trabalho na sociedade e as fronteiras de carreira são os pontos nos quais existem restrições a esse movimento.

Tais restrições podem ser mais ou menos permeáveis; isto é, podem ser cruzadas pelas pessoas com alguma facilidade ou se constituir em barreiras à mobilidade. Além disso, as fronteiras de carreira podem ser subjetivas ou objetivas. As fronteiras subjetivas de carreira são um conjunto de crenças que as pessoas possuem sobre dados tipos de transições de papeis de trabalho; mas, quando um número suficientemente grande de pessoas compartilha as mesmas crenças, as fronteiras se tornam fatos sociais objetivos.

Os supracitados estudiosos afirmam que, inicialmente, as fronteiras de carreira são formuladas como ideias nas mentes dos atores de carreira e se referem ao que estes são capazes de fazer a seguir; ou seja, assumir um novo papel de trabalho. Todavia, a visão dos atores de carreira sobre quais novos papeis de trabalho podem ser por eles assumidos também é moldada, em maior ou menor extensão, pelas interações destes com pessoas que tem poder de influencia-los, tais como seus pais, professores, mentores, colegas e profissionais do mercado. 
Quando essas premissas são compartilhadas por um número suficiente de indivíduos, especialmente por aqueles que tem capacidade de impor as suas visões para outros, emerge um consenso sobre proto-fronteiras de carreira. Estas, então, são ligadas, formando uma fronteira objetiva de carreira que começa a impactar um grupo inteiro de pessoas e o processo de cruzamento de fronteiras se torna institucionalizado.

Então, quando determinada transição de papeis é permitida a um número suficiente de atores, o movimento deixa de ser ocasional e se torna um curso normal de carreira. Essa sequência de transições de papeis de trabalho pode, assim, ser seguida por indivíduos que possuam dadas características ou que tenham tido experiências específicas.

Por fim, Gunz et al (2007) aduzem que o ator de carreira, bem como alguém com quem esse ator interage e que exerça algum poder sobre ele, pode relutar em realizar ou permitir a execução de uma determinada transição de papeis. Essas relutâncias estão ligadas à três facetas: (1) o conhecimento de que uma dada transição de papeis de trabalho existe como uma possibilidade; (2) a avaliação de exequibilidade desta transição e; (3) sua atratividade.

Para melhor compreender a interação do indivíduo e do ambiente social, Hughes e seus colaboradores da Escola de Sociologia de Chicago consideraram os componentes objetivo e subjetivo das carreiras. Hughes (1958) afirma que é no curso de uma carreira, vista como um movimento entre sequências de ofícios, que o indivíduo encontra seu lugar dentro das instituições sociais e interpreta o significado de sua vida. Assim, a dualidade subjetiva e objetiva da carreira é uma de suas propriedades críticas (BARLEY, 1989).

Uma carreira consiste, objetivamente, de uma série de status e funções claramente definidas (HUGHES, 1937); é o aspecto público ou estrutural (BARLEY, 1989) e pode ser aferida ao se observar as escolhas que a pessoa faz e as atividades nas quais ela se engaja (HALL, 2002). Carreiras objetivas são, portanto, formas institucionais de participação na sociedade (BARLEY, 1989), fazendo parte do controle social e sendo culturalmente limitadas e retoricamente reforçadas (BAILYN, 1989).

Subjetivamente, uma carreira é a perspectiva de movimento na qual a pessoa vê sua vida e interpreta o significado de seus vários atributos, ações, eventos e consequências (HUGHES, 1937). Logo, carreiras são significados subjetivamente atribuídos pelos indivíduos às 
experiências pelas quais se desenvolvem de forma a se alinharem aos eventos de suas biografias; é o sentido que as pessoas dão ao que se tornam (BARLEY, 1989).

As experiências subjetivas de carreira refletem mudanças em aspirações, satisfações, autoconceitos, valores e atitudes frente ao trabalho (HALL, 2002; WEICK; BERLINGER, 1989) e assim, as carreiras subjetivas mudam com o tempo à medida que os indivíduos alteram suas posições sociais e reconstroem seu passado e seu futuro para entrar em acordo com o seu presente (BARLEY, 1989).

Um outro aspecto fundamental da carreira é que há uma interdependência entre as suas faces objetiva e subjetiva. Khapova et al (2007) salientam que os dois lados da carreira não somente coexistem, mas influenciam um ao outro. A carreira objetiva provê a experiência de trabalho que impacta no significado que a pessoa dá a sua trajetória. Por outro lado, a interpretação da situação de carreira e as motivações individuais influenciam a forma como a carreira evolui e é vista pelos outros.

Em suma, carreiras são sociais e individuais, objetivas e subjetivas ao mesmo tempo. É, assim, um construto multidimensional, constituído por características observáveis e latentes tanto das pessoas quanto das sociedades nas quais suas carreiras evoluem. Pode-se, portanto, propor que o esquema a seguir (Figura 1) representa a interdependência dos aspectos envolvidos nas carreiras das pessoas. 


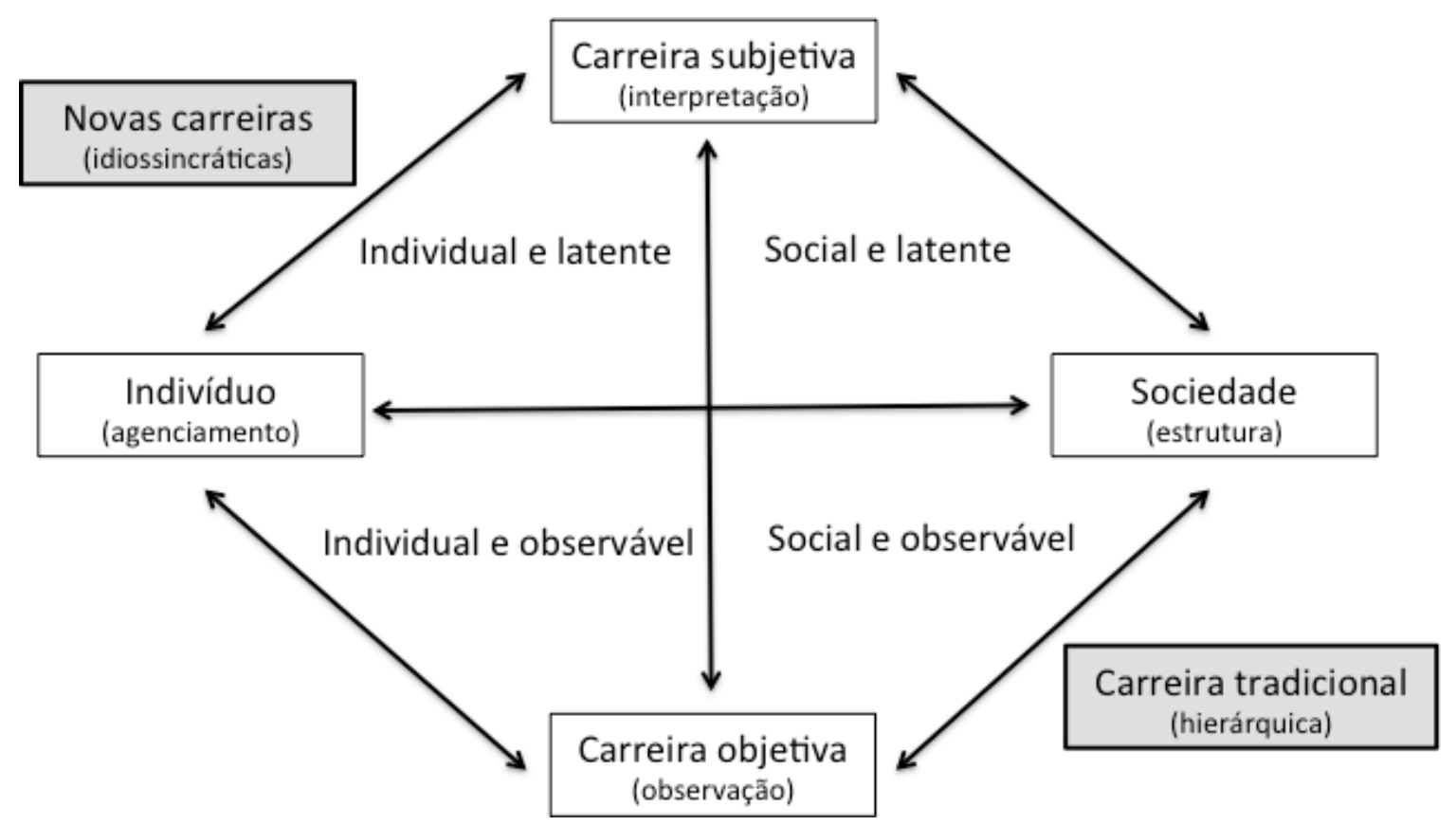

Figura 1 - Interrelações dos aspectos da carreira dos indivíduos.

Fonte: Elaborado pela autora.

Como anteriormente exposto, Hughes (1997) salienta a necessidade de se analisar as dimensões do indivíduo e da sociedade juntas quando se estuda carreiras. Assim, indivíduos possuem uma capacidade de ação (agência) e os sistemas sociais têm como propriedades um conjunto organizado de regras e de recursos (estrutura) (GIDDENS, 2003).

Para Giddens (2003), o indivíduo é dotado de uma capacidade para realizar suas motivações. Sua ação ocorre em um processo contínuo, durante o qual ele monitora reflexivamente seus atos e as consequências destes. $\mathrm{O}$ agente se comporta de acordo com o que acredita que serão os resultados de sua ação, embora nem sempre decorra o que havia sido cogitado por ele anteriormente. A consequência de uma ação, tendo ou não sido antevista, se torna a base para outra.

Assim, neste fluxo de ações é que um indivíduo vai construindo sua carreira objetivamente, movimentando-se entre ofícios e posições e, dessa forma, encontrando seu lugar dentro das instituições sociais (HUGHES, 1937). Como ser reflexivo (GIDDENS, 2003), o agente interpreta o significado de sua carreira objetiva, de suas ações e das consequências destas, conferindo sentido à sua trajetória e construindo a sua identidade (HUGHES, 1937; 1958). 
Contudo, ao agente, em suas interações sociais, cabe manipular os recursos que estejam a ele disponíveis e seguir procedimentos metodológicos que permitam a continuidade de uma sequência estabelecida de comportamentos (GIDDENS, 2003) de acordo com seu status na sociedade, ou seja, conforme um padrão de combinação de deveres e de privilégios que lhe é conferido (HUGHES, 1958).

Hughes (1958) afirma que em uma sociedade rígida e estruturada, uma carreira consiste de uma série de status e ofícios claramente definidos e que em uma sociedade mais livre, o indivíduo pode criar sua própria posição ou escolher uma dentre as que já existem.

Inglehart e Welzel (2005) indicam que houve uma mudança de valores decorrente do aumento do desenvolvimento socioeconômico da era industrial para a sociedade da informação. Para eles, como anteriormente mencionado, a ênfase cultural se alterou da disciplina coletiva para a liberdade individual, da conformidade ao grupo para a diversidade humana e do estado de autoridade para a autonomia individual.

A carreira tradicional, definida dentro do âmbito da empresa, envolve pré-estabelecidos movimentos ascendentes na pirâmide corporativa (ARTHUR; ROUSSEAU, 1996; GUEST; STURGES, 2007; HALL, 1996; 2002; SULLIVAN; 1999) e representa um modelo adequado à uma sociedade mais rígida, característico, como apontado por Inglehart e Welzel (2005), de uma era industrial.

Por outro lado, as novas carreiras, caracterizadas pelo autodirecionamento das escolhas e das ações individuais que são orientadas por desejos e valores pessoais em vez de por práticas organizacionais de gestão de carreira (HALL, 1996; LONDON; STUMPF, 1986; SULLIVAN; BARUCH, 2009), são melhor ajustadas a uma sociedade mais livre, com valores como os da sociedade da informação citados por Inglehart e Welzel (2005).

\subsection{Sucesso na carreira}

O sucesso na carreira também sofreu a mesma alteração de foco do que a carreira. Hall e Mirvis (1996) apontam que, no contexto do mercado de trabalho atual, a indisponibilidade de muitos dos fatores que apoiavam e reforçavam o sucesso característico da carreira tradicional, tais como estabilidade no emprego, aumentos salariais constantes e status do cargo e do 
empregador, impele o indivíduo a reexaminar as suas aspirações de carreira para encontrar fontes de sucesso psicológico a fim de não correr o risco de se desapontar ou de se sentir fracassado.

A emergência da carreira sem fronteiras e da carreira proteana coloca ênfase em entender o sucesso de uma perspectiva subjetiva (ARTHUR et al, 2005; GREENHAUS, 2003). Assim, é preciso que se olhe para os valores individuais com vistas à planejar a carreira e moldar a identidade profissional.

Judge e Kammeyer-Mueller (2007, p. 60) definem sucesso na carreira como "[...] as conquistas reais ou percebidas que os indivíduos acumulam como resultado de suas experiências de trabalho."4 Para Arthur et al (2005, p. 179), sucesso na carreira é uma consequência das experiências de carreira de uma pessoa e pode ser definido como "[...] a conquista de resultados desejáveis relacionados ao trabalho em algum ponto das experiências de trabalho de uma pessoa ao longo do tempo."5

Embora os dois conceitos sejam semelhantes, o primeiro entende que as conquistas podem ser tanto factuais quanto percebidas, enquanto o segundo salienta que tais conquistas devam ser desejáveis.

O sucesso na carreira tem sido medido em termos de critérios externos ou objetivos bem como de critérios internos e subjetivos (GREENHAUS, 2003). O sucesso objetivo é relativamente observável, consiste de resultados mais ou menos tangíveis (JUDGE; KAMMEYER-MUELLER, 2007), é verificável e mensurável por um terceiro imparcial (HESLIN, 2005), acessível publicamente e se refere ao papel social e à posição oficial, refletindo uma concepção de sucesso socialmente compartilhada (ARTHUR et al, 2005).

Pode ser, ainda, definido como uma perspectiva externa que descreve indicadores tangíveis da situação de carreira do indivíduo. É tipicamente medido por resultados tais como salário ou renda, ascensão ou número de promoções e status ocupacional (GREENHAUS, 2003; HESLIN, 2005; JUDGE; KAMMEYER-MUELLER, 2007).

\footnotetext{
4 “[...] the real or perceived achievements individuals have accumulated as a result of their work experiences."

5 "[...] the accomplishment of desirable work-related outcomes at any point in a person's work experience over time."
} 
Judge e Kammeyer-Mueller (2007) alegam que como o status ocupacional está relacionado às habilidades requeridas pelas atividades, ao potencial de recompensas extrínsecas e à capacidade de contribuir para a sociedade por meio do desempenho no trabalho, sociólogos frequentemente o veem como o signo mais importante de sucesso na sociedade contemporânea.

O sucesso subjetivo, por sua vez, é conceituado como uma avaliação interna do indivíduo de suas conquistas (ARTHUR et al, 2005; JUDGE; KAMMEYER-MUELLER, 2007), por meio de quaisquer dimensões que sejam importantes para si (ARTHUR et al, 2005). Hall e Mirvis (1996), o denominam como sucesso psicológico, definindo-o como a experiência de alcançar objetivos que são pessoalmente significativos ao indivíduo, ao invés daqueles determinados por pais, pares, organizações ou sociedade.

O indicador mais comum para o sucesso intrínseco na carreira é uma avaliação subjetiva da satisfação pessoal com a própria carreira, retrospectiva ou prospectivamente (HESLIN, 2005; JUDGE; KAMMEYER-MUELLER, 2007) e é mais frequentemente expressado em termos de sucesso na carreira percebido, satisfação com a carreira, com o trabalho e com a vida (GREENHAUS, 2003; HESLIN, 2005; JUDGE; KAMMEYER-MUELLER, 2007).

Judge e Kammeyer-Mueller (2007), todavia, advertem que embora a satisfação com o trabalho esteja associada à satisfação com a carreira, a primeira reflete reações emocionais imediatas do indivíduo em relação a sua atual atividade laboral, enquanto a última é mais ampla, referindo-se às experiências passadas e ao futuro potencial da história de trabalho da pessoa.

O sucesso objetivo na carreira pode ser avaliado, além de por um terceiro imparcial, pelo próprio indivíduo, utilizando-se de critérios autorreferentes ou referenciados nos outros. Os primeiros geralmente refletem padrões e aspirações do próprio indivíduo, como, por exemplo, observar que o objetivo estabelecido de alcançar um determinado nível hierárquico dentro de um dado número de anos foi atingido; enquanto os últimos são comparações com as situações de carreira de outras pessoas que o indivíduo tenha escolhido como referência, tal como, por exemplo, verificar que os seus rendimentos são mais vultosos do que os de seus ex-colegas de universidade ou que se teve um maior número de promoções do que os de seu pai na mesma idade (HESLIN, 2005). 
No que se refere ao sucesso subjetivo, como este independe de uma concepção de sucesso socialmente compartilhada, baseando-se primordialmente em aspectos que sejam pessoalmente significativos, a sua avaliação é mais frequentemente autorreferente (HESLIN, 2005).

Heslin (2005), no entanto, cita um caso especial de avaliação de sucesso subjetivo referenciado nos outros: quando há a internalização das expectativas de pessoas importantes para o indivíduo, como, por exemplo, quando se considera na avaliação do próprio sucesso o que a família acredita que pode determinar a satisfação com a carreira.

Todavia, Hall e Mirvis (1996), Arthur et al (2005) e Heslin (2005) defendem que, com o advento das novas carreiras, mais idiossincráticas e autogeridas, haverá menos guias externos pelos quais as pessoas poderão se orientar para averiguar seu sucesso na carreira, restando somente a opção de olhar para dentro de si, sondando seus valores pessoais para isto. Tal argumento leva não só a uma elevação da importância dos critérios subjetivos de sucesso, como também dos critérios autorreferentes.

Boudreau et al (1999) e Judge e Kammeyer-Mueller (2007) afirmam que sucesso intrínseco e extrínseco na carreira podem ser aferidos como resultados relativamente independentes, uma vez que estão apenas moderadamente correlacionados.

Embora haja uma relação moderada entre as duas faces do sucesso na carreira, Arthur et al (2005) argumentam que elas são interdependentes. Para estes autores, os indivíduos estão continuamente interpretando as experiências de trabalho e o sucesso experimentado influenciará as suas decisões em busca de sucesso no futuro.

Portanto, a interdependência dos aspectos (objetivo e subjetivo, individual e social) da carreira também deve estar refletida na concepção de sucesso na carreira.

Contudo, não é consensual na literatura que haja uma supremacia de uma perspectiva de sucesso sobre a outra. Para Nicholson e Waal-Andrews (2005), o contexto estabelece os limites para o sucesso objetivo pelos recursos, que governam os tipos de vantagens que podem ser asseguradas, e pela sociedade, que determina as regras pelas quais formas particulares de esforço levam ao sucesso. 
Esses autores indicam que dentro de toda sociedade o status social é o aspecto mais importante à decisão de alocação de recursos. A partir da posição social, os outros fazem inferências sobre o indivíduo em relação aos seus conhecimentos e às suas habilidades, atribuem-lhe reputação, dispõem-se a formar alianças, além de a associarem à abundância de recursos e à longevidade. Todas essas consequências levam à obtenção de mais recursos, facilitando o alcance do sucesso.

Em contraposição, ensinam que o sucesso subjetivo se constitui de aspectos que são identificáveis somente por introspecção, sem a necessidade de validação social e, portanto, com possibilidade limitada de levar ao sucesso na carreira. Assim, os autores assumem que a relação entre sucesso objetivo e subjetivo é a de que o primeiro causa o segundo.

De fato, Abele e Spurk (2009) identificaram evidências de que, no início da carreira, o sucesso objetivo influencia positivamente o sucesso subjetivo; mas, também verificaram que ao longo do tempo, o sucesso subjetivo passa a influenciar as mudanças no sucesso objetivo.

Heslin (2005) aponta que os indicadores de sucesso objetivo são valorizados pela maioria das pessoas e que, estes sob certas circunstâncias, podem conduzir a um sucesso subjetivo. Porém, argumenta que, embora importantes e valorizados, estes não são os únicos objetivos que as pessoas procuram em suas carreiras e que resultados menos tangíveis também são desejados.

Além disso, altos salários e promoções não fazem com que as pessoas necessariamente se sintam bem sucedidas (BURKE, 1999; KORMAN et al, 1981), especialmente quando os resultados objetivos são obtidos às expensas da saúde, de relações familiares ou de valores pessoais (HALL; MIRVIS, 1996).

Mais ainda, se o sucesso objetivo fosse a única causa para o sucesso subjetivo, operários e outros trabalhadores cujas carreiras não oferecem oportunidades de altos salários e de promoções não poderiam reportar o sentimento de sucesso na carreira como narrado por alguns estudos (e.g., HENNEQUIN, 2007; LUCAS; BUZZANEL, 2004). 
Dessa maneira, embora Hall e Chandler (2005) também reconheçam o potencial de o sucesso objetivo resultar em sucesso subjetivo, ressaltam que o indivíduo é quem deve realmente ser responsável pela escolha da medida pela qual o seu sucesso na carreira será avaliado.

Adicionalmente, esclarecem que o ciclo de sucesso na carreira pode ser iniciado pelo senso de chamado $^{6}$ na carreira, no qual o forte foco em um propósito, que é pessoalmente significativo e está associado ao sucesso psicológico, impele o indivíduo a empreender esforços para a sua realização, podendo resultar também na obtenção de sucesso objetivo na carreira.

Com base na discussão até agora apresentada, pode-se propor que as consequências resultantes das experiências de trabalho ao longo do tempo devam ser avaliadas tanto em termos de seus aspectos objetivo e subjetivo, quanto de seus âmbitos individual e social. Portanto, sugere-se que o construto sucesso na carreira seja definido como a conquista de resultados desejáveis de carreira, factuais ou percebidos, em algum ponto das experiências de trabalho de uma pessoa ao longo do tempo.

O estudo de Dries et al (2008) apoia empiricamente a pertinência desta definiç̧ão. A partir da técnica de escalonamento multidimensional, os autores verificaram que os critérios de sucesso na carreira relatados por vinte e dois gestores organizacionais belgas estavam dispostos em quatro quadrantes, denominados: (1) interpessoal-realização; (2) intrapessoal-realização; (3) intrapessoal-afeto e; (4) interpessoal-afeto (ver Quadro 1).

O primeiro é constituído por realizações factuais de carreira validadas pelo mundo externo ao indivíduo, tais como desempenho no alcance de resultados e de metas, avanço em termos de nível hierárquico e experiência e contribuição real para a coletividade; evidenciando, portanto, as dimensões objetiva e social do construto.

O segundo contempla as realizações factuais de carreira validadas pelo próprio indivíduo, tais como autodesenvolvimento por meio de aprendizagem e criação de algo inovador; salientando as dimensões objetiva e individual do construto.

\footnotetext{
${ }^{6}$ Hall e Chandler (2005, p. 6) definem o chamado como um "trabalho que a pessoa percebe como sendo seu propósito na vida", "advindo de uma motivação interna que não é orientada pela busca de objetivos instrumentais " $\mathrm{e}$ "com vistas a contribuir para um mundo melhor".

The calling is a "[...] work that a person perceives as his purpose in life", that "[...] comes from an internal motivation that is not driven by instrumental goal-seeking" and "that would contribute to a better world."
} 
O terceiro é composto por sentimentos e percepções sobre a carreira validados pelo indivíduo, tais como segurança e satisfação pessoal; ressaltando, por sua vez, as dimensões subjetiva e individual do construto.

O quarto e último abarca os sentimentos e as percepções sobre a carreira validados pelo mundo externo ao indivíduo, tais como reconhecimento por esforços e talentos, cooperação com as pessoas com quem trabalha e contribuição percebida para a sociedade; enfatizando a dimensão subjetiva e social do construto.

Como é possível observar no Quadro 1, são vários os critérios que emergem nas diversas pesquisas qualitativas sobre o significado de sucesso na carreira para as pessoas. Cada um dos autores classificou tais significados em alguns temas, de acordo com o sentido atribuído a eles por seus entrevistados.

Quadro 1 - Os significados de sucesso na carreira.

\begin{tabular}{|l|l|l|l|}
\hline Referência & $\begin{array}{l}\text { Tipo de pesquisa } \\
\text { e população }\end{array}$ & Fatores / temas & Itens/ componentes \\
\hline $\begin{array}{l}\text { Gattiker e } \\
\text { Larwood }\end{array}$ & $\begin{array}{l}\text { Quantitativa } \\
\text { 221 gestores e } \\
\text { pessoal de apoio de } \\
\text { sucesso }\end{array}$ & Sucesso no trabalho & $\begin{array}{l}\text { Desempenho, oportunidades de } \\
\text { desenvolvimento, responsabilidade, } \\
\text { suporte da gestão, felicidade no } \\
\text { trabalho, dedicação } \\
\text { Respeito e aceitação dos pares, boas } \\
\text { avaliações, confiança no supervisor } \\
\text { Compensação justa e alta renda } \\
\text { comparadas com os pares } \\
\text { Oportunidades de promoção, alcançar } \\
\text { metas de carreira planejadas } \\
\text { Felicidade na vida particular }\end{array}$ \\
\hline $\begin{array}{l}\text { Greenhaus } \\
\text { et al (1990) }\end{array}$ & $\begin{array}{l}\text { Quantitativa } \\
1628 \text { gestores } \\
\text { brancos e negros }\end{array}$ & $\begin{array}{l}\text { Sucesso financeiro } \\
\text { Sucesso hierárquico } \\
\text { Suances de promoção, ter atingido um } \\
\text { Satisfação com a } \\
\text { carreira }\end{array}$ & $\begin{array}{l}\text { platô } \\
\text { Satisfação com a carreira }\end{array}$ \\
\hline
\end{tabular}


Quadro 1 - O significado de sucesso na carreira (continuação).

\begin{tabular}{|c|c|c|c|}
\hline Referência & $\begin{array}{l}\text { Tipo de pesquisa } \\
\text { e população }\end{array}$ & Fatores / temas & Itens/ componentes \\
\hline $\begin{array}{l}\text { Parker e } \\
\text { Chusmir } \\
\text { (1992) }\end{array}$ & $\begin{array}{l}\text { Quantitativa } \\
756 \text { empregados em } \\
\text { geral }\end{array}$ & $\begin{array}{l}\text { Contribuição social } \\
\text { Relações familiares } \\
\text { Realização pessoal } \\
\text { Realização } \\
\text { profissional } \\
\text { Segurança }\end{array}$ & $\begin{array}{l}\text { Poder, influência, alta renda } \\
\text { comparada com os pares, bons } \\
\text { benefícios, reconhecimento, aumentos } \\
\text { salariais } \\
\text { Ajudar outras pessoas, ser útil, fazer } \\
\text { diferença, melhorar o bem estar dos } \\
\text { trabalhadores } \\
\text { Casamento feliz e estável, ser } \\
\text { bom(boa) pai(mãe), ser bem sucedido } \\
\text { na criação dos filhos } \\
\text { Paz interior, contentamento, felicidade, } \\
\text { valor pessoal, criatividade, satisfação, } \\
\text { autorrespeito, desfrutar de atividades } \\
\text { fora do trabalho } \\
\text { Competência, desempenho, } \\
\text { comprometimento, confiança do } \\
\text { supervisor, aceitação dos colegas, } \\
\text { satisfação no trabalho } \\
\text { Segurança econômica, segurança no } \\
\text { emprego }\end{array}$ \\
\hline $\begin{array}{l}\text { Sturges } \\
(1999)\end{array}$ & $\begin{array}{l}\text { Qualitativa } \\
36 \text { gestores homens } \\
\text { e mulheres }\end{array}$ & $\begin{array}{l}\text { Critérios internos de } \\
\text { sucesso } \\
\text { Critérios intangíveis } \\
\text { de sucesso } \\
\text { Critérios externos de } \\
\text { sucesso }\end{array}$ & $\begin{array}{l}\text { Competência, sentimentos de } \\
\text { realização pessoal, ter trabalho } \\
\text { interessante, integridade, equilíbrio } \\
\text { entre vida pessoal e profissional } \\
\text { Reconhecimento pessoal, ter } \\
\text { responsabilidade, ter impacto no } \\
\text { negócio, deixar uma marca na } \\
\text { organização } \\
\text { Posição (posição hierárquica, ascensão } \\
\text { e status) e recompensa (pagamento) }\end{array}$ \\
\hline $\begin{array}{l}\text { Boudreau et } \\
\text { al (1999) }\end{array}$ & $\begin{array}{l}\text { Quantitativa } \\
1885 \text { executivos } \\
\text { americanos e } \\
\text { 1871 europeus }\end{array}$ & $\begin{array}{l}\text { Critérios extrínsecos } \\
\text { de sucesso } \\
\text { Critérios intrínsecos } \\
\text { de sucesso }\end{array}$ & $\begin{array}{l}\text { Remuneração, ascensão, } \\
\text { empregabilidade, proximidade do CEO } \\
\text { Satisfação com a carreira, com o } \\
\text { trabalho e com a vida }\end{array}$ \\
\hline $\begin{array}{l}\text { Friedman e } \\
\text { Greenhaus } \\
(2000)\end{array}$ & $\begin{array}{l}\text { Quantitativa } \\
800 \text { profissionais de } \\
\text { negócios }\end{array}$ & $\begin{array}{l}\text { Status } \\
\text { Tempo para si } \\
\text { Desafio } \\
\text { Segurança } \\
\text { Social }\end{array}$ & $\begin{array}{l}\text { Status social, prestígio, poder, ter alta } \\
\text { remuneração, avançar rapidamente } \\
\text { Flexibilidade para determinar horário } \\
\text { de trabalho, ter tempo para si e para a } \\
\text { família } \\
\text { Desafios, criatividade e prazer } \\
\text { Emprego estável, aposentadoria } \\
\text { assegurada e viver no local preferido } \\
\text { Ajudar outras pessoas, ser respeitado } \\
\text { pelos outros no trabalho }\end{array}$ \\
\hline $\begin{array}{l}\text { Seibert et al } \\
(2001)\end{array}$ & $\begin{array}{l}\text { Quantitativa } \\
448 \text { empregados }\end{array}$ & $\begin{array}{l}\text { Sucesso extrínseco } \\
\text { Sucesso intrínseco }\end{array}$ & $\begin{array}{l}\text { Promoções e pagamento } \\
\text { Satisfação com a carreira }\end{array}$ \\
\hline
\end{tabular}


Quadro 1 - O significado de sucesso na carreira (continuação).

\begin{tabular}{|c|c|c|c|}
\hline Referência & $\begin{array}{l}\text { Tipo de pesquisa } \\
\text { e população }\end{array}$ & Fatores / temas & Itens/ componentes \\
\hline Nabi (2001) & $\begin{array}{l}\text { Quantitativa } \\
439 \text { pessoal } \\
\text { administrativo }\end{array}$ & $\begin{array}{l}\text { Sucesso extrínseco } \\
\text { no trabalho } \\
\text { Sucesso intrínseco no } \\
\text { trabalho }\end{array}$ & $\begin{array}{l}\text { Pagamento justo, salário equitativo, } \\
\text { suficiente responsabilidade no } \\
\text { trabalho, oportunidades de promoção } \\
\text { Felicidade no trabalho, suporte do } \\
\text { supervisor, gostar do trabalho que faz, } \\
\text { gostar dos colegas, obter boas } \\
\text { avaliações de desempenho, contar com } \\
\text { os colegas, receber confiança do } \\
\text { supervisor }\end{array}$ \\
\hline $\begin{array}{l}\text { Eby et al } \\
(2003)\end{array}$ & $\begin{array}{l}\text { Quantitativa } \\
411 \text { trabalhadores } \\
\text { sem fronteiras }\end{array}$ & $\begin{array}{l}\text { Sucesso psicológico } \\
\text { Empregabilidade }\end{array}$ & $\begin{array}{l}\text { Sucesso na carreira percebido } \\
\text { Empregabilidade interna e externa } \\
\text { percebidas }\end{array}$ \\
\hline $\begin{array}{l}\text { Dyke e } \\
\text { Murphy } \\
\text { (2006) }\end{array}$ & $\begin{array}{l}\text { Qualitativa } \\
40 \text { gestores homens } \\
\text { e mulheres de } \\
\text { sucesso }\end{array}$ & $\begin{array}{l}\text { Equilíbrio na vida } \\
\text { Relacionamento } \\
\text { Reconhecimento } \\
\text { Sucesso material } \\
\text { Contribuição } \\
\text { Liberdade }\end{array}$ & $\begin{array}{l}\text { Equilíbrio vida pessoal e profissional, } \\
\text { ser feliz, estar de bem consigo mesmo, } \\
\text { realização pessoal, crescimento } \\
\text { pessoal } \\
\text { Ter bons relacionamentos dentro e } \\
\text { fora do ambiente de trabalho, } \\
\text { desenvolver pessoas } \\
\text { Ser bem sucedido em um desafio, ser } \\
\text { reconhecido como competente e aceito } \\
\text { por clientes } \\
\text { Recompensa financeira, viver sem } \\
\text { problemas financeiros } \\
\text { Estar contribuindo } \\
\text { Liberdade de escolher o que quer para } \\
\text { si }\end{array}$ \\
\hline $\begin{array}{l}\text { Lee et al } \\
(2006)\end{array}$ & $\begin{array}{l}\text { Qualitativa } \\
87 \text { profissionais de } \\
\text { meio período }\end{array}$ & $\begin{array}{l}\text { Temas da } \\
\text { organização } \\
\text { Temas pessoais } \\
\text { Temas interligados }\end{array}$ & $\begin{array}{l}\text { Respeito dos pares, mobilidade } \\
\text { ascendente, apreciação / } \\
\text { reconhecimento } \\
\text { Ter uma vida fora do trabalho, } \\
\text { aprendizado, crescimento e ser } \\
\text { desafiado, diversão e prazer / ter um } \\
\text { trabalho interessante } \\
\text { Ter bom desempenho, ter impacto / } \\
\text { fazer contribuições } \\
\end{array}$ \\
\hline $\begin{array}{l}\text { Hennequin } \\
(2007)\end{array}$ & $\begin{array}{l}\text { Qualitativa } \\
25 \text { operários }\end{array}$ & $\begin{array}{l}\text { Sucesso material } \\
\text { Sucesso psicológico } \\
\text { Sucesso social }\end{array}$ & $\begin{array}{l}\text { Recompensas monetárias, benefícios } \\
\text { adicionais, posição hierárquica, } \\
\text { número de promoções } \\
\text { Satisfação com a carreira, sucesso no } \\
\text { emprego, sucesso interpessoal, } \\
\text { equilíbrio na vida } \\
\text { Status social, reconhecimento, } \\
\text { reputação }\end{array}$ \\
\hline $\begin{array}{l}\text { Dries et al } \\
(2008)\end{array}$ & $\begin{array}{l}\text { Qualitativa } \\
22 \text { gestores }\end{array}$ & $\begin{array}{l}\text { Realização } \\
\text { interpessoal } \\
\text { Realização } \\
\text { intrapessoal } \\
\text { Afeto intrapessoal } \\
\text { Afeto interpessoal }\end{array}$ & $\begin{array}{l}\text { Desempenho, avanço, contribuição } \\
\text { factual } \\
\text { Autodesenvolvimento, criatividade } \\
\text { Segurança, satisfação } \\
\text { Reconhecimento, cooperação, } \\
\text { contribuição percebida }\end{array}$ \\
\hline
\end{tabular}


Quadro 1 - O significado de sucesso na carreira (continuação).

\begin{tabular}{|c|c|c|c|}
\hline Referência & $\begin{array}{l}\text { Tipo de pesquisa } \\
\text { e população }\end{array}$ & Fatores / temas & Itens/ componentes \\
\hline Costa (2010) & $\begin{array}{l}\text { Quantitativo } \\
366 \text { pessoas ligadas } \\
\text { à universidade }\end{array}$ & $\begin{array}{l}\text { Subjetiva } \\
\text { Equilíbrio } \\
\text { Objetiva }\end{array}$ & $\begin{array}{l}\text { Empregabilidade, criatividade, } \\
\text { desenvolvimento, cooperação, } \\
\text { competência, contribuição, valores, } \\
\text { identidade } \\
\text { Equilíbrio vida pessoal-profissional } \\
\text { Remuneração, hierarquia }\end{array}$ \\
\hline $\begin{array}{l}\text { Demel et al } \\
\text { (2012) }\end{array}$ & $\begin{array}{l}\text { Qualitativa } \\
226 \text { enfermeiros, } \\
\text { gestores e operários }\end{array}$ & $\begin{array}{l}\text { Temas pessoais } \\
\text { Temas de trabalho } \\
\text { Interação com o } \\
\text { ambiente }\end{array}$ & $\begin{array}{l}\text { Satisfação com o trabalho e com o } \\
\text { emprego, conquistas (promoções, } \\
\text { salário, realização financeira), } \\
\text { aprendizado e desenvolvimento } \\
\text { (crescimento pessoal, desenvolvimento } \\
\text { de habilidades, concluir a educação } \\
\text { formal), autorrealização } \\
\text { Segurança no emprego, características } \\
\text { do trabalho (responsabilidade, } \\
\text { desafios, autonomia, escopo e } \\
\text { variedade das tarefas, interação, ter o } \\
\text { trabalho que se deseja), desempenho, } \\
\text { contribuir para o sucesso da empresa } \\
\text { Ambiente social de trabalho (rede de } \\
\text { relacionamentos), reconhecimento } \\
\text { (feedbacks positivos, ser respeitado), } \\
\text { equilíbrio vida-profissão, fazer } \\
\text { diferença para os outros ou a sociedade } \\
\text { (ajudar os outros, transferir } \\
\text { conhecimento, desenvolver os outros) }\end{array}$ \\
\hline
\end{tabular}

FONTE: Adaptado de DRIES; 2011, p. 375; DRIES; PEPERMANS; CARLIER; 2008, p. 262 e de HENNEQUIN; 2007, p. 569 e ampliado pela autora.

Como fica evidente a partir da leitura do Quadro 1, as pessoas apontam diferentes critérios objetivos como, por exemplo, renda, segurança, status e promoção, e subjetivos, tais como aprendizado e equilíbrio entre vida pessoal e profissional para avaliar sucesso na carreira.

Arthur et al (2005) notaram que 57\% dos 68 artigos com pesquisas empíricas levantados por eles exploravam critérios objetivos e subjetivos de sucesso na carreira, enquanto $28 \%$ se concentravam apenas no sucesso objetivo e $15 \%$ no sucesso subjetivo.

Embora haja uma predominância de artigos que se apoiam em critérios objetivos para avaliar o sucesso na carreira, os critérios subjetivos estão sendo cada vez mais adotados na pesquisa ultimamente (HESLIN, 2005). Muito provavelmente, este fenômeno decorre da mudança do conceito tradicional de carreira (com foco nos aspectos objetivos e sociais da carreira) para o 
de novas carreiras (que inclui as dimensões subjetivas e individuais da carreira em seu escopo).

De fato, como afirmam Dries et al (2008), o sucesso subjetivo na carreira tem se destacado porque os pesquisadores estão mais conscientes atualmente de que o sucesso na carreira é uma construção individual, social e dinâmica, que evolui junto com os contextos históricos e culturais, e não uma realidade objetiva e estática.

Assim, em vez de compreender o sucesso na carreira como uma variável percebida consensual e factualmente, admite-se que diferentes interpretações sejam possíveis para o que sucesso na carreira pode significar, considerando, assim, a multidimensionalidade do construto.

Destarte, recomendou-se que mais pesquisas qualitativas fossem conduzidas no intuito de identificar os critérios utilizados pelas pessoas para avaliarem sucesso na carreira (e.g., ARTHUR et al, 2005; HESLIN, 2005).

Arthur et al (2005), por exemplo, argumentam que como a responsabilidade pelo desenvolvimento da carreira e pela interpretação do sucesso na carreira cabem ao indivíduo, os critérios para averiguar o sucesso na carreira deveriam ser da própria pessoa. Notam, ainda, que nenhum dos 68 artigos analisados indagou diretamente os respondentes sobre quais eram seus critérios e questionam a adequação da investigação do sucesso subjetivo na carreira.

Ademais, as escalas de satisfação na carreira utilizadas atualmente pela maior parte das pesquisas quantitativas são limitadas em sua abrangência, no sentido de que não contemplam todas as dimensões possíveis que as pessoas podem usar para definir e avaliar o sucesso na carreira (ARTHUR et al, 2005).

No entanto, como afirmam Dries et al (2008), mesmo que fosse possível chegar a uma lista de todos os critérios de sucesso na carreira idiossincráticos usados pelas pessoas, o princípio da parcimônia e a viabilidade da construção de um instrumento avaliativo estariam prejudicados. 
Por outro lado, Dries (2011) afirma que os poucos estudos que exploraram e mediram os significados subjetivos que as pessoas atribuem ao sucesso na carreira apresentam considerável justaposição entre diferentes populações, culturas e épocas.

Mayrhofer et al (2012), ao se referirem ao estudo relatado por Demel et al (2012), realizado em onze países do mundo, com enfermeiros, executivos e operários de diversas idades concluíram que os significados de sucesso na carreira levantados pelos indivíduos podem ser agrupados em quatro categorias: questões pessoais, recompensas materiais, pertencimento à organização e interação com o ambiente mais amplo.

Assim sendo, as pesquisas qualitativas sobre o significado de sucesso na carreira realizadas até o momento, embora em pequena quantidade, fornecem uma base inicial para a estruturação de um instrumento de medida para pesquisas quantitativas que considerem a multidimensionalidade do construto. $\mathrm{O}$ instrumento, assim, deve contemplar os quatro temas mencionados por Mayrhofer et al (2012) de forma suficientemente abrangente para que pessoas de sexos, idades e origens diferentes tenham suas acepções de sucesso na carreira representadas.

Algumas características individuais se refletem na escolha dos critérios pelos quais se avalia sucesso na carreira. Encontrou-se, por exemplo, que mulheres valorizam sentimentos de realização e desenvolvimento no trabalho e que homens medem seu sucesso na carreira por meio de dinheiro, avanço e poder que obtêm (GREENHAUS, 2003; MAINIERO; SULLIVAN, 2006; NG et al, 2005; STURGES, 1999).

Em seu estudo qualitativo, Dyke e Murphy (2006) verificaram que as mulheres valorizam o trabalho pelas oportunidades de crescimento pessoal e de reconhecimento, mas de forma que possam equilibrar vida pessoal e profissional e manter relacionamentos saudáveis. Por seu turno, homens geralmente valorizam o sucesso material e os relacionamentos e se importam em contribuir para a organização e para a sociedade e em serem livres para buscar o que desejam.

Eddleston e Powell (2008) também verificaram que homens atribuem maior importância à critérios associados à obtenção de status do que mulheres e que estas, em contrapartida, valorizam mais relacionamentos e contribuição para a sociedade. 
Todavia, a dimensão masculina da identidade de gênero intermedia a relação entre sexo e preferências por critérios baseados em status e a dimensão feminina tem o mesmo efeito sobre as preferências por critérios de relacionamento e de contribuição para a sociedade (EDDLESTON; POWELL, 2008). Ou seja, homens com maiores escores em identidade de gênero feminino tendem a ter critérios de sucesso mais próximos aos das mulheres e estas, quando obtêm altas pontuações em identidade de gênero masculino, optam mais comumente por critérios citados pelos homens.

Os mais jovens, independentemente de gênero, ressaltam em maior proporção critérios objetivos do que os mais velhos, que recorrem aos critérios mais subjetivos de sucesso para aferir o quão bem estão se saindo em suas carreiras (MAINIERO; SULLIVAN, 2006; HAY; HODGKINSON, 2006). Os critérios materiais são substituídos por autonomia e influência à medida que as pessoas amadurecem (STURGES, 1999).

Unite et al (2012) encontraram em um estudo transcultural que pessoas mais jovens tendem a compreender o sucesso na carreira em termos de conquistas, trabalhos desafiadores e que exigem responsabilidade e equilíbrio entre vida pessoal e profissional mais frequentemente do que os mais velhos. Já estes indicam que sucesso é fazer diferença, ter bom desempenho no trabalho e cumprir o seu papel, diferentemente do que os mais jovens.

Lee et al (2006) descobriram que obter o respeito dos pares e contribuir para os resultados organizacionais é mais importante para profissionais do que para gerentes que, por sua vez, valorizam mais a mobilidade ascendente, recompensas monetárias e aumentos de status do que os profissionais.

Profissionais e gerentes não diferem na importância que dão ao reconhecimento nãofinanceiro recebido pela organização, a dedicarem tempo e esforços para a família ou objetivos pessoais, a realizarem um bom trabalho e a se sentirem desafiados e estimulados intelectualmente por um trabalho que seja interessante, prazeroso e que desenvolva as suas habilidades e expanda seu conhecimento (LEE et al, 2006).

Gerentes compreendem que sucesso na carreira é um construto que inclui as dimensões de desempenho, avanço, autodesenvolvimento, criatividade, segurança, satisfação, 
reconhecimento, cooperação e contribuição, dando centralidade às questões de aprendizado (DRIES et al, 2008).

Em contrapartida, para operários, dimensões importantes de tal construto são recompensas materiais, benefícios adicionais, posição hierárquica, número de promoções, satisfação com a carreira, sucesso no emprego, sucesso interpessoal, equilíbrio entre vida pessoal e profissional, status social, reconhecimento e reputação (HENNEQUIN, 2007).

Pode-se assim notar que diversos temas são comuns às duas populações; no entanto, o autodesenvolvimento, a criatividade, a segurança e a contribuição emergem apenas dentre os gerentes, enquanto recompensas materiais e benefícios e status social são percebidos somente dentre os operários.

Da mesma forma, Demel et al (2012) encontraram diferenças nas definições de sucesso entre enfermeiros, gestores e operários. Conforme os autores, os enfermeiros definem sucesso em termos de fazer diferença no mundo ao ajudar os outros e de serem reconhecidos. Além disso, são os que menos priorizam recompensas materiais em suas definições de sucesso.

Para os operários, as recompensas materiais e a segurança são importantes, embora não definam sucesso em termos de promoção ou aprendizagem e desenvolvimento. Os gestores, contudo, definem sucesso tanto em termos de fazer diferença no mundo quanto de obter recompensas materiais; todavia, priorizam muito mais do que os outros dois grupos o equilíbrio na vida. Vale notar que para os três grupos conquistas na carreira e satisfação se revelaram importantes critérios de sucesso na carreira (DEMEL et al, 2012).

O momento histórico e a cultura também influenciam a definição de sucesso na carreira. Conforme Dries (2011), sucesso na carreira na sociedade agrária, na qual os trabalhos eram herdados da família, era avaliado pela sobrevivência física, pela segurança e pelo desenvolvimento de caráter. $\mathrm{Na}$ sociedade industrial, com suas estruturas organizacionais hierárquicas, o sucesso na carreira passou a ser verificado por conquistas mensuráveis, tais como renda, posição e status.

Com a globalização e as reestruturações organizacionais, os marcadores de sucesso na carreira das épocas anteriores se tornaram mais incertos, fazendo com que sucesso na carreira 
passasse a abarcar objetivos mais amplos e pessoais. Assim, a transição da sociedade industrial para a sociedade do conhecimento foi caracterizada por uma mudança de valores: valores de auto-expressão foram enfatizados em detrimento de valores de racionais-seculares (INGLEHART; WELZEL, 2005).

Nesse contexto, Dries (2011) sugere que se verifique como a mudança de valores influencia a definição de sucesso na carreira para as pessoas. Ademais, Brown (2002) formula a hipótese de que pessoas com valores individualistas tem bases primárias para a satisfação com o trabalho diferentes das de indivíduos que priorizam valores coletivistas. 


\section{VALORES INDIVIDUAIS}

O estudo dos valores é um campo de interesse de diversas áreas do conhecimento, tais como filosofia, economia, artes, sociologia, psicologia e antropologia (KLUCKHOHN, 1951). Conforme Hitlin e Piliavin (2004), ainda existe pouca coerência entre os conceitos adotados em diversos estudos e os valores são comumente confundidos com atitudes, traços, normas e necessidades.

Todavia, Schwartz desenvolveu uma teoria que, ao longo de seus anos de pesquisa, tornou-se amplamente referenciada por estudiosos de todo o mundo (SCHWARTZ, 2011), trazendo alguma unicidade para a compreensão dos valores e de suas relações com outras variáveis.

\subsection{Valores individuais: conceito e estrutura}

Kluckhohn (1951) afirma que o único consenso existente na literatura de sua época era de que valores estavam relacionados a proposições normativas - o que se quer (desejo) e o que se deve querer (desejável) - e não a proposições existenciais - o que se acredita que seja. Em sua visão, os valores estabeleceriam os limites dos custos permitidos de uma gratificação ou de uma realização de acordo com as consequências para partes do ou para todo o sistema social.

Portanto, a sua definição de valor é "uma concepção, explícita ou implícita, distinta da característica de um indivíduo ou grupo, do desejável que influencia a seleção de disponíveis modos, meios e fins de uma ação." 7 (KLUCKHOHN, 1951, p. 395). Hitlin e Piliavin (2004) apontam a visão funcionalista e determinista desta concepção, uma vez que ela indica que valores são imperativos culturais que necessariamente levam a certas ações.

$\mathrm{Na}$ visão de Rokeach (1979), os valores individuais são concepções socialmente compartilhadas do que é desejável. Tais concepções são o resultado da aprendizagem advinda da ação de forças externas e internas sobre o indivíduo; podendo, assim, ser entendidas como representações cognitivas das necessidades internas mediadas pelas pressões externas.

\footnotetext{
7 "A value is a conception, explicit or implicit, distinctive of an individual or characteristic of a group, of the desirable which influences the selection from available modes, means, and ends of action."
} 
De acordo com a sua concepção, valores são representações cognitivas das necessidades subjacentes ao indivíduo após encamparem objetivos e demandas institucionais. Assim, Rokeach, ao salientar a desajabilidade pessoal e social dos modos de conduta preferenciais, evidencia que os valores dão significado às ações (HITLIN; PILIAVIN, 2004).

Rokeach (1979) ainda segmenta os valores em dois tipos: terminais e instrumentais. Os primeiros são crenças ou concepções sobre objetivos finais ou estados finais de existência desejáveis e, os seguintes se referem a crenças ou concepções sobre modos de se comportar que são instrumentais para a obtenção do estado final desejável.

Além disso, sugere que o número de valores humanos seja pequeno e o mesmo em todo o mundo e que as pessoas não difiram em termos da presença ou da ausência de determinados valores, mas em suas hierarquias ou prioridades atribuídas a eles.

Com base nos conceitos de valores individuais oferecidos pela literatura, Schwartz e Bilsky (1987; 1990) os definiram como princípios ou crenças sobre estados de existência ou modelos de comportamentos desejáveis, que transcendem situações específicas, que guiam a seleção ou a avaliação de comportamentos e eventos e que estão organizados pela sua importância relativa. Posteriormente, Schwartz (1994) conceitua valores como objetivos transituacionais desejáveis, que variam em importância e servem como princípios orientadores na vida de uma pessoa ou outra entidade social.

Ao serem analisados, os conceitos de valores apresentados trazem diversos elementos: (1) se referem a objetivos finais ou estados finais de existência desejáveis ou modos de se comportar; (2) se relacionam à proposições normativas e não existenciais; (3) desenvolvem-se pela aprendizagem advinda da ação de forças externas e internas; (4) guiam a seleção ou a avaliação de comportamentos; (5) transcendem situações específicas; (6) são os mesmos em todo o mundo; e (7) se organizam em hierarquias ou preferências.

O primeiro elemento introduz a diferença entre valores terminais e instrumentais indicada por Rokeach (1979). Como já mencionado, os valores são crenças ou concepções sobre objetivos ou estados de existência finais (valores terminais) ou sobre modos de se comportar para obter o estado final desejável (instrumentais), sendo que os valores instrumentais descrevem comportamentos que facilitam a obtenção dos valores terminais. 
Embora Schwartz e Bilsky $(1987$; 1990) tenham considerado a diferenciação entre valores terminais e valores instrumentais proposta por Rokeach em seu modelo, Schwartz (1994) concluiu que não existiam evidências para tal distinção na estrutura de valores das pessoas.

Por seu turno, Meglino e Ravlin (1998), em sua revisão da literatura, relataram enfrentar dificuldades em separar estudos que tinham como foco os valores instrumentais daqueles que tratavam de valores terminais. É possível que isto tenha ocorrido, pois todo valor instrumental pode ser conceituado como terminal e vice versa (SCHWARTZ, 1994).

O segundo elemento diferencia as proposições existenciais das normativas. Kluckhohn (1951) afirma que proposições existenciais se prestam a descrever a natureza e as interrelações dos fenômenos naturais; ou seja, são descritivas e objetivas.

Meglino e Ravlin (1998) corroboram esta observação ao reconhecerem que objetos e resultados não têm um valor inato; o valor é atribuído a eles por alguém. As proposições normativas, por sua vez, são premissas sobre o que é desejado ou desejável, são valorativas e subjetivas; portanto, expressam os valores individuais.

O terceiro elemento traz informações sobre como os valores são desenvolvidos. Conforme Rokeach (1979), Schwartz e Bilsky (1987; 1990) e Schwartz (1994), existem três questões universais que todos os indivíduos devem enfrentar: necessidades biológicas do organismo, requisitos de coordenar interações sociais e requisitos para o funcionamento tranquilo e a sobrevivência dos grupos.

$\mathrm{Na}$ interação entre as forças internas (requisitos biológicos) e as forças externas (requisitos sociais e institucionais), grupos e indivíduos cognitivamente transformam as necessidades inerentes à existência humana em uma linguagem de valores específicos para enfrentar a realidade em um contexto social.

Essa transformação acontece por meio do amadurecimento cognitivo e do processo de socialização, no qual os indivíduos aprendem os termos culturalmente compartilhados que os permitem expressarem os seus objetivos ou valores. 
Os valores individuais, portanto, são transmitidos de geração para geração no processo de socialização das pessoas; a mídia, os pais, os professores, os amigos, a religião e diversos outros grupos sociais, aos quais elas pertençam, estão envolvidos no processo para as aculturar (PORTO, 2004). Assim, os valores refletem aquilo que os indivíduos percebem, aprendem e internalizam (KNAFO; SCHWARTZ, 2004) como sendo bom ou mau, justo ou injusto, prioritário ou não.

O processo de internalização, no entanto, não é passivo como o termo transmissão possa sugerir; características dos indivíduos interferem na maneira que eles percebem e aceitam os valores de seus grupos de referência (KNAFO; SCHWARTZ, 2004).

Os variados contextos de socialização se interrelacionam na construção do sistema de valores individual, uma vez que cada uma das interações com grupos de referência diferentes leva à percepção de que existem diversos valores que são apropriados para o funcionamento social bem sucedido, levando-os a questionar e reorganizar os valores anteriormente esposados (KUCZYNSKI; NAVARA, 2006).

Assim, a internalização dos valores aceitos ocorre em um processo de confronto e reconciliação entre a satisfação de suas próprias necessidades individuais de acordo com seu sistema de valores e a conformidade aos valores majoritários dos grupos sociais importantes para ele (ROHAN, 2000).

Entretanto, se por um lado as diversas fontes de socialização oferecem um conjunto mais variado de valores, por outro, as fontes de socialização da família, de pares, da comunidade, da escola, do trabalho e da mídia estão inseridos em um sistema cultural de crenças mais amplo, que está subjacente a eles, os interrelaciona e os influencia, fazendo com que uns tendam a reforçar os outros, pois este sistema cultural define a variedade e o foco da variação pessoal que é aceitável e recompensada (ARNETT, 2007).

Logo, à medida que os valores culturais mudam, em função de fatos históricos, econômicos, políticos, tecnológicos e sociais, novos valores devem ser internalizados (ARNETT, 2007; KUCZYNSKI; NAVARA, 2006). 
Inglehart e Welzel (2005) apontam tais mudanças em seu modelo. Conforme esses autores, as inovações tecnológicas, o crescimento da produtividade, o aumento da expectativa de vida e dos níveis educacionais, o maior acesso à informação e a maior diversidade e complexidade sociais da era contemporânea elevaram a importância das relações de troca e de barganha nas transações comerciais e cívicas.

Assim, para os autores, as relações de autoridade e a conformidade aos interesses comunitários da era industrial dos séculos XIX e XX perderam espaço. A retirada de tais restrições da autonomia humana tendeu a remodelar as orientações de valores das pessoas, levando-as a adotar valores de auto-expressão que ressaltam a autonomia, a emancipação e a liberdade de escolha individual. Com isto, elas passaram a demandar e a defender a liberdade, o que levou as instituições a estabelecerem direitos democráticos que lhes asseguraram o exercício de sua autonomia e da livre escolha em suas atividades.

Em vista do exposto, percebe-se que os valores especificam as crenças pessoais sobre como o indivíduo deve se comportar em seu ambiente social. Assim, o quarto elemento propõe que os valores de uma pessoa não necessariamente refletem como ela quer ou deseja se comportar, mas, em vez disso, eles descrevem as interpretações internalizadas sobre formas socialmente desejáveis de satisfazer as suas necessidades (MEGLINO; RAVLIN, 1998).

Rohan (2000), ao discutir essa questão, sugere que os aspectos do querer e do dever se comportar de determinada forma podem ser integrados ao se entender os valores prioritários como uma evidência da organização dinâmica dos julgamentos sobre a capacidade que as entidades (e.g., coisas, pessoas, ações, atividades) têm de possibilitarem a melhor forma possível de se viver; ou seja, não somente satisfazendo necessidades de sobrevivência, mas permitindo que se viva tão prazerosa e produtivamente quanto possível.

O quinto elemento traz a suposição de que os valores são transituacionais. Rohan (2000) indica que a ligação afetiva ao sistema de valores está relacionada à motivação que as pessoas têm de se engajarem em situações, se relacionarem com outras pessoas e se comportarem de determinadas formas que são similares a outras que resultaram em afetos positivos ou reduziram afeto negativo. Assim, a autora continua, as pessoas podem ter preferência por certas emoções. É isto que Schwartz e Bilsky (1987; 1990) denominam como objetivos motivacionais universais, o sexto elemento do conceito de valores. 
Schwartz e Bilsky (1987; 1990), em seus estudos iniciais, propuseram a existência de oito domínios motivacionais. Schwartz, ao dar continuidade à pesquisa sobre valores, consegue apoio de pesquisadores de diversos países para realizar um estudo transcultural e o publica em 1992 (SCHWARTZ, 2011).

A partir de então, Schwartz (1994) define os dez domínios motivacionais de valores como: poder, realização, hedonismo, estimulação, autodirecionamento, universalismo, benevolência, tradição, conformidade, segurança (Quadro 2). Diversos estudos posteriores (e.g., BILSKY et al, 2011; CIECIUCH; SCHWARTZ, 2012; FISCHER et al, 2011; SCHWARTZ et al, 2001; TAMAYO, 2007) suportam a relativa estabilidade e universalidade desses dez domínios motivacionais de valores.

Quadro 2 - Os dez domínios motivacionais dos valores.

\begin{tabular}{|c|c|c|}
\hline Domínio & Definição & Valores \\
\hline Poder & $\begin{array}{l}\text { Status e prestígio social, controle ou } \\
\text { domínio sobre pessoas e recursos. }\end{array}$ & $\begin{array}{l}\text { Poder social; reconhecimento social; } \\
\text { preservar a imagem pública; autoridade; } \\
\text { riqueza }\end{array}$ \\
\hline Realização & $\begin{array}{l}\text { Sucesso pessoal por meio } \\
\text { demonstração de competência } \\
\text { acordo com padrões sociais. }\end{array}$ & $\begin{array}{l}\text { Bem sucedido; ambicioso; capaz; } \\
\text { influente; inteligente }\end{array}$ \\
\hline Hedonismo & Prazer e gratificação sensual para si. & Prazer; que goza a vida \\
\hline Estimulação & Excitação, novidade e desafio na vida. & Audacioso; vida variada; vida excitante \\
\hline Autodirecionamento & $\begin{array}{l}\text { Pensamento e ação independentes - } \\
\text { escolher, criar e explorar. }\end{array}$ & $\begin{array}{l}\text { Independente; criatividade; curioso; } \\
\text { liberdade; escolhe as próprias metas; } \\
\text { auto-respeito }\end{array}$ \\
\hline Universalismo & $\begin{array}{l}\text { Entender, apreciar, tolerar e proteger o } \\
\text { bem estar de todas as pessoas e da } \\
\text { natureza. }\end{array}$ & $\begin{array}{l}\text { Proteger o meio ambiente; unidade com a } \\
\text { natureza; mundo de beleza; mente aberta; } \\
\text { mundo em paz; justiça social; igualdade; } \\
\text { sabedoria; harmonia interna }\end{array}$ \\
\hline Benevolência & $\begin{array}{l}\text { Preservação e melhoria do bem estar } \\
\text { das pessoas com quem se tem } \\
\text { frequente contato pessoal. }\end{array}$ & $\begin{array}{l}\text { Leal; prestativo; honesto; responsável; } \\
\text { vida espiritual; amizade verdadeira; amor } \\
\text { maduro; sentido da vida }\end{array}$ \\
\hline Tradição & $\begin{array}{l}\text { Respeito, comprometimento e } \\
\text { aceitação dos costumes e ideias que a } \\
\text { cultura tradicional ou a religião } \\
\text { proveem. }\end{array}$ & $\begin{array}{l}\text { Devoto; ciente dos meus limites; humilde; } \\
\text { respeito pela tradição; moderado; } \\
\text { desprendimento }\end{array}$ \\
\hline Conformidade & $\begin{array}{l}\text { Restrição de ações, inclinações e } \\
\text { impulsos que podem chatear ou } \\
\text { machucar os outros e violar } \\
\text { expectativas ou normas sociais. }\end{array}$ & $\begin{array}{l}\text { Respeito pelos pais e pelos mais velhos; } \\
\text { obediente; polidez; autodisciplina }\end{array}$ \\
\hline Segurança & $\begin{array}{l}\text { Segurança, harmonia e estabilidade da } \\
\text { sociedade, das relações e de si mesmo. }\end{array}$ & $\begin{array}{l}\text { Limpo; segurança nacional; ordem social; } \\
\text { segurança familiar; reciprocidade de } \\
\text { favores; senso de pertencer; saudável }\end{array}$ \\
\hline
\end{tabular}

Fonte: Adaptado de SCHWARTZ; 1994, p. 22 e BILSKY; SCHWARTZ; 1994, p. 167. 
O sétimo e último elemento diz respeito à forma como os valores estão organizados, formando um continuum de motivações interligadas (SCHWARTZ, 1994) que se apresentam em uma estrutura circular e estão ordenados pela importância relativa aos demais (SCHWARTZ, 2005).

Além disso, duas dimensões motivacionais bipolares estruturam um sistema de dez valores humanos: abertura à mudança versus conservação e autotranscendência versus autopromoção (SCHWARTZ; BILSKY, 1987; 1990). A primeira dimensão, abertura à mudança versus conservação, ordena os valores com base na motivação da pessoa para pensar e agir independentemente, favorecendo a mudança (autodirecionamento e estimulação), em oposição à tendência a salientar valores de preservação do status quo, enfatizando a autorrestrição, as práticas tradicionais e a proteção da estabilidade (segurança, conformidade e tradição).

A segunda dimensão, autopromoção versus autotranscendência, contrasta valores que destacam a aceitação dos outros como iguais e a preocupação com o seu bem estar (universalismo e benevolência) com valores que dão prioridade à busca do próprio sucesso e do domínio sobre os outros (poder e realização). $\mathrm{O}$ valor hedonismo está relacionado tanto à abertura à mudança quanto à autopromoção.

Para Schwartz (1994), a chave para identificar as relações entre os valores é a suposição de que ações tomadas em cada tipo de valor têm consequências psicológicas, práticas e sociais que podem conflitar ou serem compatíveis com a busca por outras esferas valorativas. Domínios de valores que competem entre si estão localizados em direções opostas em relação ao centro; já os tipos compatíveis estão próximos.

Assim sendo, observa-se que poder e realização enfatizam a superioridade social e a estima; realização e hedonismo focam na satisfação autocentrada; hedonismo e estimulação abrangem um desejo por excitação afetivamente prazerosa; estimulação e autodirecionamento envolvem interesse intrínseco por novidade e maestria; autodirecionamento e universalismo expressam confiança sobre o próprio julgamento e o conforto com a diversidade da existência; universalismo e benevolência estão preocupados com a melhoria dos outros e expressam interesses que transcendem o egoísmo; benevolência e conformidade requerem comportamentos normativos que fomentam relacionamentos próximos; benevolência e 
tradição promovem devoção aos outros do grupo; conformidade e tradição implicam a subordinação de si em favor das expectativas impostas socialmente; tradição e segurança acentuam a preservação dos arranjos sociais existentes que dão certeza à vida; conformidade e segurança destacam a proteção da ordem e da harmonia nas relações; segurança e poder acentuam evitar ou superar as ameaças da incerteza por meio do controle de relações e recursos (SCHWARTZ, 1994).

Schwartz et al (2006) ainda propõem a denominação dos eixos. Tal proposição foi suportada empiricamente pelos estudos de Fontaine et al (2008) com 38 países e de Fischer et al (2011) nas 27 unidades federativas do Brasil.

O eixo horizontal tem como polaridades o individual (poder, realização, hedonismo, estimulação, autonomia) - a forma como os interesses individuais são expressos - e o coletivo (benevolência, universalismo, tradição, conformidade e segurança) - os tipos de relações sociais que se têm com os outros e a forma como eles influenciam o sucesso individual na busca da satisfação de seus interesses.

Fischer et al (2011) explicam que as pessoas necessitam sobreviver em um ambiente hostil, e que, para isso, precisam estabelecer relações e laços próximos com outros indivíduos, como também manter a capacidade de tomar decisões individuais sobre a sua própria sobrevivência, para resistir pessoalmente a ameaçadoras demandas do grupo e para satisfazer a necessidade de um senso de controle interno e autonomia. Indivíduos guiados por valores sociais são orientados para a sociedade ou para relações interpessoais. Em contraste, pessoas preferencialmente guiadas por valores individuais são autocentradas ou tem foco intrapessoal.

O eixo vertical opõe defesa (conformidade, tradição, segurança, poder) e crescimento (hedonismo, estimulação, autodirecionamento, universalismo e benevolência). Os valores do domínio motivacional de realização pertencem às duas categorias. Este eixo, segundo Fischer et al (2011) inclui necessidades materiais que requerem a sua satisfação para assegurar a sobrevivência do indivíduo, do grupo social imediato e da espécie (defesa) e necessidades menos materiais que podem aumentar quando as necessidades básicas tenham sido satisfeitas, tais como necessidades de informação, estimulação intelectual e emocional e aspirações para aumentar a autoestima (crescimento). 
Uma ênfase nos valores de defesa implica preocupações com termos mais biológicos de sobrevivência, estabilidade pessoal e segurança que ajudam a controlar a ansiedade gerada pela incerteza existente na natureza e na sociedade. O conjunto de valores de crescimento revela uma orientação universal, enfatizando princípios e ideias abstratos, incluindo uma ênfase no espírito inovador e menos dependência de bens materiais, expressando as motivações quando a ansiedade está ausente e representando a busca de recompensas ou de ganhos intrínsecos ou extrínsecos.

A Figura 2, a seguir, apresenta a estrutura do sistema de valores com os seus domínios motivacionais, as suas dimensões e os seus eixos.

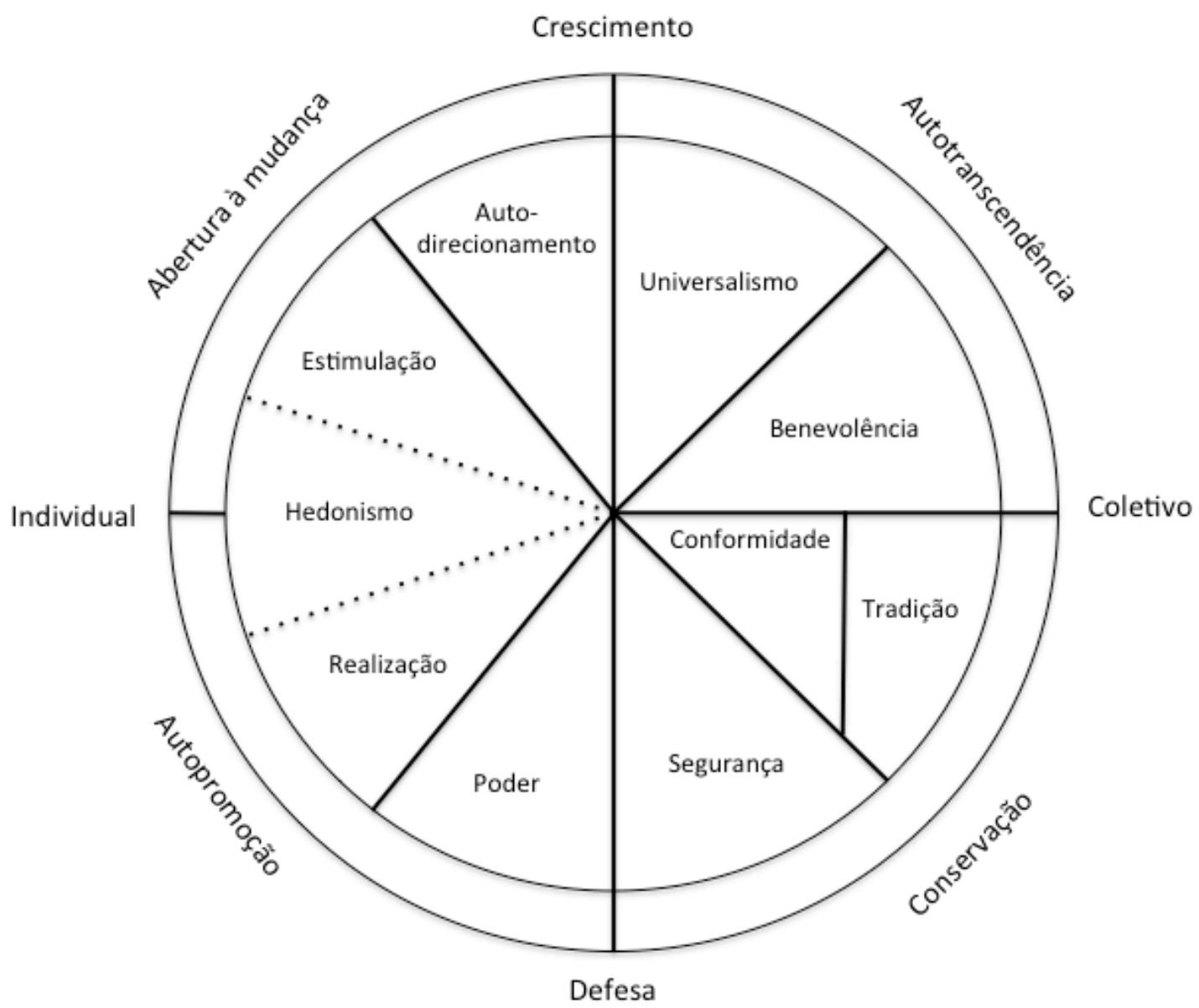

Figura 2 - Estrutura do sistema de valores.

FONTE: Adaptado de FONTAINE et al; 2008, p. 354. 


\subsection{Valores individuais: relações com variáveis individuais e contextuais}

Como exposto anteriormente, valores são critérios que os indivíduos usam para julgar a desejabilidade de comportamentos, de pessoas e de eventos (BILSKY; SCHWARTZ, 1994; PARKS; GUAY, 2009; ROCCAS et al, 2002) aprendidos ao longo do processo de socialização (PARKS; GUAY, 2009).

Além disso, os valores se referem aos objetivos intencionais do indivíduo, sendo perseguidos em detrimento de outros de acordo com a importância atribuída a objetivos particulares (BILSKY; SCHWARTZ, 1994; PARKS; GUAY, 2009) e têm uma estrutura dinâmica e maleável de acordo com as circunstâncias aos quais as pessoas estão expostas (PARKS; GUAY, 2009).

Sugere-se que as prioridades dadas a determinados valores humanos podem predizer atitudes e comportamentos (ROHAN, 2000). Também se sabe que diversas características individuais (e.g., gênero, idade e escolaridade), bem como características contextuais (e.g., país, densidade de coabitantes) interferem nas preferências por valores que as pessoas possuem (e.g., BARDI; GOODWIN, 2011).

Schwartz (2005) e Schwartz et al (2006) sugerem que as situações da vida das pessoas proporcionam oportunidades para a expressão de alguns valores mais facilmente do que outros. O tipo de ocupação, o estado civil e a posição dentro da família, bem como o contexto mais amplo tornam a busca por determinados valores mais complicada ou mais recompensadora. Assim, as pessoas adaptam as suas preferências por determinados valores às circunstâncias.

Os indivíduos aumentam a prioridade de valores que são prontamente obtidos e reduzem a importância daqueles que não conseguem alcançar; todavia, para valores relacionados ao bem estar material e à segurança, a privação aumenta a força de tais necessidades e, consequentemente, a sua centralidade (SCHWARTZ; BARDI, 1997).

As características individuais, tais como idade, escolaridade e sexo, comumente estão relacionadas às experiências de aprendizagem, aos papéis sociais desempenhados, às aspirações, às sanções encontradas e às capacidades desenvolvidas. Portanto, tais atributos 
diferenciam as circunstâncias de vida dos indivíduos, contribuindo para as suas preferências por alguns valores (SCHWARTZ et al, 2006).

Embora a intenção não seja fazer uma revisão bibliográfica exaustiva sobre todas as relações existentes entre os valores prioritários e outras variáveis individuais e contextuais, algumas delas serão abordadas a seguir.

\section{Valores e variáveis individuais}

Meglino e Ravlin (1998), ao analisarem a literatura sobre valores entre 1987 e 1997, afirmam que a quantidade de pesquisa que examina os efeitos de diversas variáveis demográficas sobre os valores diminuiu consideravelmente. No entanto, alguns estudos sugerem associações entre valores e sexo, idade, escolaridade, renda e especialidade profissional escolhida.

Além de não existirem muitas investigações sobre as relações entre o sexo dos pesquisados e valores, os resultados são geralmente inconsistentes (HITLIN; PILIAVIN, 2004). Todavia, Schwartz et al (2006) mencionam que se acredita que as diferenças de valores entre mulheres e homens sejam pequenas.

Com relação à estrutura do sistema de valores proposta por Schwartz, dois estudos indicam uma ampla consistência entre ambos os sexos, tendo encontrado, no entanto, diferenças na localização de apenas dois valores, um em cada estudo.

Struch et al (2002) verificaram que apenas o valor "segurança nacional" apresentou diferenças de significado entre os sexos, tendendo a se apresentar próximo dos valores de poder para homens e dos valores de benevolência e conformidade para as mulheres. Isto sugere que eles entendem segurança nacional mais em termos de força e competição do que elas e menos em termos de cooperação e normas compartilhadas.

Por sua vez, Prince-Gibson e Schwartz (1998), embora também não tenham encontrado diferenças relativas ao sexo do respondente na estrutura do sistema de valores, observaram que o valor igualdade é compreendido de forma diferente por homens e mulheres israelenses. 
Os homens posicionam o valor igualdade no tipo motivacional de universalismo, compreendendo-o, portanto, como igualdade de oportunidades para todos. As mulheres, todavia, o alocam entre os tipos motivacionais de realização e de poder, implicando em um entendimento de que o valor igualdade se relaciona à obtenção dos próprios interesses por meio de superioridade social e autoestima.

Com relação às diferenças nos valores prioritários no que tange ao sexo dos indivíduos, os estudos são mais inconclusivos, mas apontam algumas tendências gerais. Prince-Gibson e Schwartz (1998) não encontraram distinções nos valores preferenciais. Já Schwartz e outros pesquisadores apresentam alguns estudos que verificaram a existência de tais diferenças.

Oito tipos de domínios motivacionais indicaram diferenciações no estudo de Schwartz et al (2006) em vinte países europeus; as exceções foram conformidade e tradição. Mulheres priorizam valores de segurança, benevolência e universalismo, enquanto homens valorizam autodirecionamento, estimulação, hedonismo, realização e poder.

Também encontrou-se que mulheres em Israel atribuem maior prioridade à benevolência e na África do Sul à tradição quando comparadas aos homens; na Itália, homens priorizam valores de estimulação mais frequentemente do que mulheres (SCHWARTZ et al, 2001). Hitlin e Piliavin (2004) afirmam que o sexo influencia, no mínimo, a seleção da área de estudos e, portanto, a estratificação da força de trabalho.

Tamayo (2007) apurou tais distinções nas prioridade de valores entre brasileiros e brasileiras. Hedonismo e estimulação tinham mais alta prioridade para os homens. Com relação aos tipos de valores benevolência, tradição, conformidade, segurança e universalismo, as mulheres indicavam maior importância do que os homens. Assim, concluiu-se que os homens preferem valores que servem aos interesses individuais, enquanto as mulheres enfatizam valores que se prestam à coletividade.

Conforme Schwartz (2005), teorias psicanalíticas, feministas e evolucionárias das diferenças relativas ao sexo dos indivíduos levam pesquisadores de valores a postularem que homens enfatizam valores instrumentais de ação, por exemplo, poder; enquanto mulheres salientam valores comunais de expressão tais como benevolência. 
Acadêmicos que estudam papeis sociais, por sua vez, indicam que meninos e meninas tipicamente são socializados para ocupar papeis diferentes e para afirmar diferentes objetivos de vida. As crianças são punidas por falharem nessa tentativa. Essas teorias compartilham uma visão de mulher mais relacional, expressiva e comunal e de homem como mais autônomo, instrumental e ativo, explicando as diferenças de prioridades atribuídas aos valores entre as pessoas de ambos os sexos.

Desde a década de 1970, existem estudos indicando a associação entre as prioridades de valores e a idade. Usando a forma D do Rokeach Value Survey, Feather (1977) encontrou que alguns valores decrescem em importância à medida que as pessoas envelhecem (vida excitante, liberdade, imaginativo e mente aberta), enquanto outros se tornam mais salientes (segurança familiar, autorrespeito, polidez e limpo).

Schwartz et al (2006) e Schwartz et al (2001) descobriram que valores de conservação e autotranscendência eram priorizados à medida que se envelhece e que valores de abertura à mudança e de autopromoção decrescem em importância.

Prince-Gibson e Schwartz (1998) encontraram a relação entre valores preferenciais e idade já evidenciada pela literatura: pessoas mais velhas enfatizam valores de tradição e de benevolência e reduzem a importância de valores de realização, de hedonismo e de estimulação.

Schwartz (2005) afirma que as mudanças de valores de acordo com a idade são originadas de três fontes: envelhecimento físico, fases da vida e eventos históricos que impactaram em faixas etárias específicas (gerações).

A perda de vitalidade com o envelhecimento físico exige um ambiente mais seguro e previsível, livre de ameaças e de riscos, alavancando valores de segurança e reduzindo valores de estimulação. Junto com o envelhecimento, também há um embotamento dos sentidos, diminuindo a importância dos valores de hedonismo. Talvez a maior consciência da própria mortalidade eleve a compaixão e o entendimento sobre o sofrimento no mundo e o respeito à fragilidade da natureza, salientando os valores de universalismo. 
A tarefa central dos jovens é mudar da dependência para a independência, decrescendo a importância dos valores de conformidade e de tradição, e aumentado a dos valores de autodirecionamento. No início da idade adulta, a preocupação principal do indivíduo é firmarse no mundo do trabalho e da família; é quando ele está sendo desafiado e tem muitas oportunidades, o que incita à busca de valores de realização e de estimulação.

No meio da idade adulta, os indivíduos têm família, trabalho e relações sociais estabelecidos; a necessidade de manter o status quo e de proteger as pessoas queridas enfatiza valores de segurança, de conformidade e de tradição e reduz os de estimulação e de realização.

As oportunidades de expressão de realização, de poder, de estimulação e de hedonismo são ainda mais reduzidas com a aposentadoria e, por vezes, a viuvez. Todavia, o comprometimento com padrões habituais torna os valores de segurança e de tradição mais importantes.

Schwartz e Bardi (1997) indicam que os valores preferenciais são mais suscetíveis à mudança na adolescência e que, portanto, as pessoas mais jovens se adaptam mais rapidamente às transformações nas circunstâncias da vida do que as mais velhas. Assim, eventos históricos que impactaram na formação dos valores na adolescência tendem a se perpetuar ao longo da vida.

Indivíduos que vivenciaram mais insegurança física e financeira atribuirão maior importância para valores materialistas em sua vida (SCHWARTZ; BARDI, 1997). Os autores afirmam que nas últimas décadas, no entanto, muitos países prosperaram, diminuindo ameaças existenciais e aumentando a possibilidade de satisfação individual e de liberdade de escolha. Isto permitiu que as faixas etárias mais baixas atribuíssem maior prioridade a valores de abertura à mudança e de universalismo e menor prioridade a valores de conservação.

Danis et al (2011), em uma pesquisa com gestores e estudantes de administração da República Checa, encontraram que a geração que iniciou sua vida laboral antes da transição política do país (anterior a 1990) valorizava mais as dimensões de conservação e de autopromoção do que a geração mais jovem, pós-transição; esta, por sua vez, conferiu maior prioridade às dimensões de abertura à mudança e de autotranscendência do que a geração que a antecedeu. 
O suporte ao impacto das diferenças geracionais e não de estágio da vida nos valores é defendido pelos autores com o argumento de que outros estudos verificaram um aumento de valores pró-sociais e um declínio de valores de autopromoção com o envelhecimento, mas os dados levantados indicaram que os mais jovens esposam mais valores de autotranscendência e menos valores de autopromoção do que os mais velhos.

Evidências de diferenças geracionais nos valores prioritários também foram encontradas por Egri e Ralston (2004) em um estudo com 774 chineses de quatro gerações e 1.004 americanos de três gerações.

Sugere-se que níveis de escolaridade sejam determinantes das prioridades de valores individuais. Steinmetz et al (2009) concluíram que pessoas com menores níveis de escolaridade conferiram maior prioridade aos valores de conservação (segurança, tradição e conformidade) do que as mais escolarizadas.

Estudos observaram que indivíduos com mais altos níveis de escolaridade salientavam valores de autodirecionamento, de estimulação (PRINCE-GIBSON; SCHWARTZ, 1998; SCHWARTZ et al, 2001; SCHWARTZ et al, 2006), de universalismo (PRINCE-GIBSON; SCHWARTZ, 1998; SCHWARTZ et al, 2006) e de realização (SCHWARTZ et al, 2006) e priorizavam menos valores de conformidade e de tradição (PRINCE-GIBSON; SCHWARTZ, 1998; SCHWARTZ et al, 2001; SCHWARTZ et al, 2006), de poder (PRINCE-GIBSON; SCHWARTZ, 1998) e de segurança (SCHWARTZ et al, 2006).

Os autores tendem a explicar essas relações também com base nas oportunidades oferecidas pelos estudos e experiências adquiridas na vida escolar. A educação proporciona maior abertura e flexibilidade intelectual, liberdade de ação e uma ampla visão de mundo, ajudando a ser mais aberto a ideias e atividades incomuns.

No entanto, tais capacidades desafiam a aceitação de normas, de expectativas e de tradições sem questionamento. Assim, pessoas com maior nível de escolaridade também tendem ter empregos cujas condições de trabalho apresentam essas características. 
A educação ainda desenvolve conhecimentos e habilidades que fortalecem a confiança e a eficácia dos indivíduos ao lidar com incertezas e os ajuda a encontrar empregos financeiramente mais seguros.

Por fim, Schwartz et al (2006) indicam que a renda facilita o envolvimento dos indivíduos em atividades que desejam e a escolha do próprio estilo de vida, reduzindo ameaças à segurança e à necessidade de controlar impulsos e de se manterem ligados a fontes de suporte tradicionais.

Como resultado, uma renda alta aumenta a importância de valores de estimulação, de autodirecionamento, de poder e de realização e diminui a importância atribuída à segurança, à conformidade e à tradição.

Escolhas de cursos são um indicador significante dos objetivos e ambições dos indivíduos e, como consequência, dos seus valores. Os estudantes da área socioeconômica (economia, contabilidade, administração) de Israel atribuíram maior importância a valores de poder e de realização, enquanto os estudantes de humanidades (língua e literatura, história, filosofia) ressaltaram os valores de universalismo e de tradição (SCHWARTZ et al, 2001).

Gandal et al (2005) averiguaram que estudantes de ciências econômicas salientaram valores de realização, de hedonismo e de poder e conferiram menor importância a valores de universalismo do que estudantes de outros cursos.

Tamayo et al (1998) também observaram as diferenças nas prioridades de valores de advogados e músicos no Brasil e encontraram que os escores foram superiores para advogados nos domínios motivacionais de conformidade, de poder e de segurança e para músicos nos de estimulação e de hedonismo.

\section{Valores e variáveis contextuais}

Schwartz e Bardi (2001) reportaram que existe um consenso geral sobre a ordem hierárquica dos valores no mundo. Eles averiguaram, em 56 países, que benevolência é frequentemente alocada como o valor mais importante, seguida por autodirecionamento, universalismo, segurança, conformidade, realização, hedonismo, estimulação, tradição e poder. 
Não obstante, alguns países africanos subsaarianos, cujo contexto social é caracterizado por famílias numerosas coabitando e por uma situação econômica restritiva, notadamente diferiram desta ordem e posicionaram conformidade em primeiro lugar. Assim, os valores prioritários das pessoas também são influenciados pelas condições sociais, políticas e econômicas de onde vivem.

Com relação ao desenvolvimento socioeconômico, verifica-se que os valores de crescimento e de defesa são mais contrastados em regiões ou em países mais desenvolvidos do que nos menos desenvolvidos (BILSKY et al, 2011; FISCHER et al, 2011). Para estes autores, a redução das restrições existenciais para as escolhas humanas proporcionadas pelos recursos individuais e o consequente encorajamento da autonomia e da liberdade de expressão oferecem às pessoas mais oportunidades e obrigações de fazerem escolhas - o principal veículo para desenvolver articulados sistemas de valores.

Isto acentua a capacidade de diferenciação entre as polaridades do eixo crescimento versus defesa. Sem recursos individuais suficientes, pessoas não diferenciam fortemente entre valores referentes aos tipos de motivadores, pois valores de crescimento serão assimilados e interpretados de formas materialistas, a fim de que auxiliem na sobrevivência.

Fischer et al (2011), no entanto, averiguaram que a densidade de coabitação pode ser mais impactante para a distinção dos valores do que a condição socioeconômica. A inclusão do índice de vivência social no modelo contou para a variância mais do que o indicador socioeconômico.

Da mesma forma, valores representativos das orientações individual e social foram menos discernidos entre pessoas que vivem em locais com menores níveis de desenvolvimento (FISCHER et al, 2011). Em contextos sociais mais pobres, as taxas de natalidade são mais altas e os recursos econômicos limitados, significando que as pessoas são forçadas a compartilhar espaço de vivência.

Assim, indivíduos desde jovens são socializados para serem interdependentes de outros. As demandas e normas do grupo são mais propensas a serem internalizadas e, portanto, a distinção entre valores orientados para si e para os outros é menos saliente. 
Danis et al (2011) reconheceram diferenças nas prioridades de valores de indivíduos que estavam no mercado de trabalho antes e depois da mudança política da República Tcheca. Defenderam, portanto, que a explicação para a formação e para a mudança de valores parece ser mais multifacetada, pois para os autores, é necessário se considerar à adaptação ao ambiente institucional prevalente, que encampa os domínios político, social e econômico.

Schwartz e Bardi (1997), no mesmo sentido, indicaram que era mais adequado explicar as diferenças de prioridades de valores pelo impacto da vivência em um país comunista do que pelo nível de desenvolvimento socioeconômico do país.

Ao analisar valores individuais em vinte países capitalistas, Schwartz (2007) afirmou que pessoas em sociedades que adotaram um modelo de capitalismo competitivo atribuem maior importância à realização, à conformidade e ao poder e menos ao universalismo e ao autodirecionamento do que sociedades com economias mais colaborativas.

Como benevolência, autodirecionamento e universalismo estão entre os três valores mais importantes e, portanto, desejáveis entre as nações, e conformidade, realização e poder estão entre posições menos importantes e, assim, menos desejáveis (SCHWARTZ; BARDI, 2001), considera-se que economias mais competitivas e direcionadas para o mercado podem aumentar a importância dos valores avaliados como menos moralmente desejáveis e reduzir a prioridade de dois dos três valores mais desejáveis entre as nações.

Schwartz e Sagie (2000) verificaram que quanto maiores os níveis de desenvolvimento econômico e de democratização do país, maior a importância atribuída a valores de autodirecionamento, de estimulação, de universalismo, de benevolência e de hedonismo e menor a importância de poder, de conformidade e de segurança.

Desenvolvimento socioeconômico também apresentou correlação positiva com valores de tradição e negativa com de realização. Encontrou-se ainda que o consenso entre as prioridades de valores de indivíduos em países com alto desenvolvimento econômico é maior do que em países com baixo desenvolvimento econômico e que o nível de democratização tem efeito inverso. 
Assim sendo, pode-se concluir que maiores níveis de desenvolvimento socioeconômico, menores taxas de coabitação ou regime político capitalista contribuem para o aumento nas prioridades de valores individualistas e de crescimento. Enquanto viver em locais com baixo desenvolvimento socioeconômico, altas taxas de coabitação ou regime político comunista tendem a salientar valores de orientação social e de defesa. 


\section{SUCESSO NA CARREIRA E VALORES INDIVIDUAIS}

Alguns pesquisadores já levantaram a definição do que vem a ser sucesso na carreira para diferentes populações (e.g., DRIES et al, 2008; DYKE; MURPHY, 2006; HAY; HODGKINSON, 2006; HENNEQUIN, 2007; LEE et al; 2006; STURGES, 1999), porém, ainda não se tem conhecimento sobre o que influencia a escolha dos critérios que essas pessoas utilizam para julgarem se são bem ou mal sucedidas na carreira.

Conforme Kuczynski e Navara (2006), valores estão presentes sempre que pessoas julgam algumas formas de agir, pensar ou sentir como mais desejáveis, úteis ou importantes do que outras. Assim, uma dessas influências pode advir do sistema de valores individual.

Como anteriormente mencionado, para adequarem as suas necessidades internas à vida social de forma bem sucedida, os indivíduos aprendem quais comportamentos, pensamentos e sentimentos são desejáveis ou aceitos em seu meio ao longo do processo de socialização, que dentre outras funções, tem a de internalização dos valores - o processo pelo qual valores anteriormente assumidos como externos são incorporados pelo indivíduo como sendo seus (GRUSEC; GOODNOW, 1994).

Todavia, as relações de socialização não são unidirecionais, nas quais os indivíduos são recipientes das mensagens culturais transmitidas pela sociedade; tais processos são, na verdade, bidirecionais e dialéticos, uma vez que ambas as partes em interação se influenciam mutuamente, observam as restrições e as oportunidades dadas pelo contexto e agem com autonomia na relação (KNAFO; SCHWARTZ, 2004; KUCZYNSKI; NAVARA, 2006).

Portanto, o processo de internalização tem três características principais interligadas: é realizado por meio das interações sociais que impõem restrições e oferecem oportunidades de ação, é bidirecional e é uma construção dialética.

O processo de socialização tem o seu início na primeira infância, com a família sendo seu principal agente. Kuczynski e Navara (2006), sobre as restrições e as oportunidades do processo de socialização, argumentam que da mesma forma que o ambiente limita a agência humana ao canalizar significado e impor limites às escolhas individuais, os pais estão em posição de restringir e de orientar os processos de internalização de valores dos filhos. 
Arnett (2007) pontua que crianças e adolescentes têm limitada liberdade para escolher os seus contextos de socialização, porque a maioria dessas escolhas são feitas ou estruturadas por seus pais. Contudo, bem como o contexto social oferece oportunidades de ação aos indivíduos, a relação entre pais e filhos também incorpora elementos permissivos para que as crianças exercitem sua agência ou negociem a natureza das restrições que lhes são impostas.

Assim, ao mesmo tempo em que os pais comunicam quais comportamentos são aceitáveis ou intoleráveis, os filhos descobrem o quão elásticos são os valores de seus genitores e o espaço que existe para sua própria criatividade na interpretação da situação ou resistência às demandas dos seus pais.

O processo de socialização é bidirecional. As crianças são ativas no seu próprio desenvolvimento, pois elas percebem, interpretam, avaliam, aceitam ou rejeitam as mensagens dos pais, influenciando as escolhas parentais de disciplina e de suas estratégias de socialização, uma vez que a resistência ou as expressões de protesto por parte das crianças podem levar os pais a modificarem as práticas de criação dos filhos ou à reflexão sobre suas posições e consequente refinamento de argumentos ou mudança de valores (KUCZYNSKI; NAVARA, 2006).

Os supramencionados autores ainda apontam que muitos aspectos da vida dos pais são alterados pela chegada da criança, o que pode fazê-los reavaliar e adaptar seus valores em suas decisões de criação do filho para que este, no futuro, alcance sucesso e bem estar.

À medida que os filhos crescem, desenvolvem outras relações sociais, deparando-se com informações e perspectivas que contradizem ou competem com os pontos de vista dos pais. Assim, eles podem desafiar os padrões, os hábitos e os valores de seus pais, causando reexame ou mudança nos comportamentos destes últimos.

Por seu turno, os filhos também devem reconciliar as visões dos pais com aquelas oferecidas por outros significativos, confrontando-as com as suas próprias necessidades e propósitos em um processo de autorreflexão, decidindo se aceitam, administram ou criativamente interpretam tais informações. 
Kuczynski e Navara (2006) afirmam que as crianças ativamente constroem ideias sobre o que é desejável nas situações sociais. A partir das mensagens que lhes são transmitidas, por meio de comunicação explícita ou modelo de conduta, elas interpretam tais informações em termos de seu próprio entendimento e as adaptam para que se adequem às tarefas imediatas, de acordo com seus propósitos e necessidades.

Entende-se, portanto, que o processo de internalização seja dialético, e, assim, a interpretação das mensagens e a adaptação da informação cultural criam novos significados e possibilidades de ação que são devolvidos à cultura. Essa síntese elaborada e externalizada pelo indivíduo se torna a base para um novo ciclo de interação e a formação de uma nova síntese.

Como salientam Rohan (2000) e Kuczynski e Navara (2006), a internalização dos valores ocorre em um processo de confronto e reconciliação entre a satisfação das necessidades individuais e a conformidade aos valores dos outros com quem se interage de uma forma dinâmica.

Portanto, a essência da visão dialética é que pessoas interagindo com seus ambientes se encontram em um contexto em mudança e que o conteúdo da internalização de um indivíduo, bem como a sua conformidade às pressões de socialização fazem parte de um processo contínuo, de forma que a síntese individual externalizada na interação contém os elementos que estabelecem o estágio para posterior mudança.

À medida que o indivíduo faz a transição da infância para a adolescência e, por fím, para a fase adulta, as suas fontes de informações culturais se tornam mais variadas, sendo transmitidas também por pares e amigos, escola, trabalho, mídia, grupo religioso e outras instituições sociais (ARNETT, 2007; KUCZYNSKI; NAVARA, 2006; PORTO, 2004), tornando a influência parental progressivamente menos exclusiva (ARNETT, 2007; KUCZYNSKI; NAVARA, 2006).

Em um âmbito mais amplo, como salienta Arnett (2007), os indivíduos obtêm cada vez maior liberdade de escolha sobre as pessoas, as instituições e os mercados com quem interagem, de forma que o processo de socialização passa a não ser imposto por forças sociais ou institucionais, mas escolhido pelo próprio indivíduo. Dessa maneira, os adultos selecionam as suas trajetórias de vida ao administrarem as oportunidades e as restrições dos contextos 
sociais aos quais estão inseridos por opção. Os papéis de pai/mãe, cônjuge e trabalhador estabelecem seus padrões de comportamento e influenciam novamente seus valores.

Como anteriormente salientado, os variados contextos de socialização se interrelacionam na construção do sistema de valores individual, à medida que os diferentes grupos de referência evidenciam a existência de diversos valores apropriados ao funcionamento social bem sucedido, levando-os a questionar e reorganizar os valores já esposados (KUCZYNSKI; NAVARA, 2006).

Embora as diversas fontes de socialização ofereçam um conjunto mais variado de valores, elas estão inseridas em um subjacente sistema cultural mais amplo de crenças, fazendo com que se reforcem mutuamente (ARNETT, 2007). Assim, quando os valores culturais mudam, novos valores devem ser internalizados (ARNETT, 2007; KUCZYNSKI; NAVARA, 2006).

Para Mayer (2004), as trajetórias de vida da sociedade industrializada eram bem definidas e institucionalizadas. Por exemplo, no âmbito da trajetória da vida produtiva, os indivíduos realizavam transições ordenadas entre escola, treinamento, emprego e aposentadoria. Tal trajetória tinha como marco a progressão e a acumulação material, mas também a conformidade às regras estabelecidas pela economia e pela família. Tal contexto, como já salientado, está associado à carreira tradicional orientada pela organização da era industrial (ARTHUR; ROUSSEAU, 1996; GUEST; STURGES, 2007; HALL, 1996; 2002; SULLIVAN; 1999) e aos valores racionais-seculares (INGLEHART; WELZEL, 2005).

As trajetórias individuais na sociedade pós-industrial, entretanto, podem ser caracterizadas por uma crescente despadronização e uma maior heterogeneidade dos cursos de vida: o tempo de escolarização se estendeu, os treinamentos se tornaram mais variados, amplos em escopo e continuados ao longo da vida e as relações de emprego se tornaram mais flexíveis e contingenciais (MAYER, 2004).

Nesse sentido, ao tempo em que as instituições têm perdido seu poder, indivíduos vem desenvolvendo maior controle e responsabilidade sobre as direções de suas vidas e, também, de suas carreiras. Assim, as pessoas não estão mais tão restritas pelas instituições, contudo, também têm menor apoio dessas, devendo se responsabilizar sozinhas por suas escolhas (ARNETT, 2007; INGLEHART; WELZEL, 2005). 
Inglehart e Welzel (2005) pontuam que a sociedade pós-moderna elevou os valores de autoexpressão, que enfatizam a autonomia, a escolha individual, a criatividade e a emancipação da autoridade; o que, por sua vez, enfraqueceu ainda mais as instituições e ampliou a diversidade de sistemas de valores individuais na população.

Todavia, conjuntos de valores diferenciados ainda são transmitidos para grupos de pessoas com determinadas características. Dyke e Murphy (2006), por exemplo, ao discutir a formação de valores de meninos e meninas, afirmam que aqueles continuam sendo socializados para serem agentes e provedores e para restringirem a expressão de suas emoções, enquanto estas são socializadas para cuidar dos outros e expressarem-se emocionalmente.

Assim, concluem os autores, não é surpreendente que a noção de sucesso para homens esteja centrada na provisão de bens materiais para a sua família e que a de mulheres esteja associada ao desenvolvimento de relacionamentos significativos.

Independentemente do sexo das pessoas, os sistemas de valores individuais estão relacionados às escolhas dos cursos superiores por universitários, de seus valores laborais (PORTO, 2004) e de seus interesses vocacionais (SAGIV, 2002). Pode-se supor, então, que também tenham impacto na adoção de critérios para avaliar o sucesso na carreira por indivíduos diferentes.

O estudo de Gorgievski et al (2011) demonstra que os valores individuais de pequenos empreendedores está relativamente bem alinhado aos critérios utilizados para aferir o sucesso de seus próprios negócios. Ademais, gestores com distintos conjuntos de valores prioritários obtêm recompensas financeiras diferenciadas (Orpen, 1976).

Sendo os valores individuais conceituados como objetivos transituacionais desejáveis, que variam em importância e servem como princípios orientadores na vida de uma pessoa (SCHWARTZ, 1994), os quais nas sociedades pós-industriais apresentam uma maior heterogeneidade do que nas anteriores (INGLEHART; WELZEL, 2005), e o sucesso na carreira definido como a conquista de resultados desejáveis de carreira, factuais ou percebidos, em algum ponto das experiências de trabalho de uma pessoa ao longo do tempo, pode-se supor que, os critérios de sucesso na carreira selecionados pelas pessoas estarão relacionados ao seu sistema de valores formado em seu processo de socialização. 
Em outras palavras, propõe-se que os modelos apresentados neste estudo estejam associados de forma que os sistemas de valores dos indivíduos e os critérios de sucesso na carreira utilizados pelos respondentes se correlacionem. O modelo a seguir representa a proposição que será testada neste estudo (Figura 3).

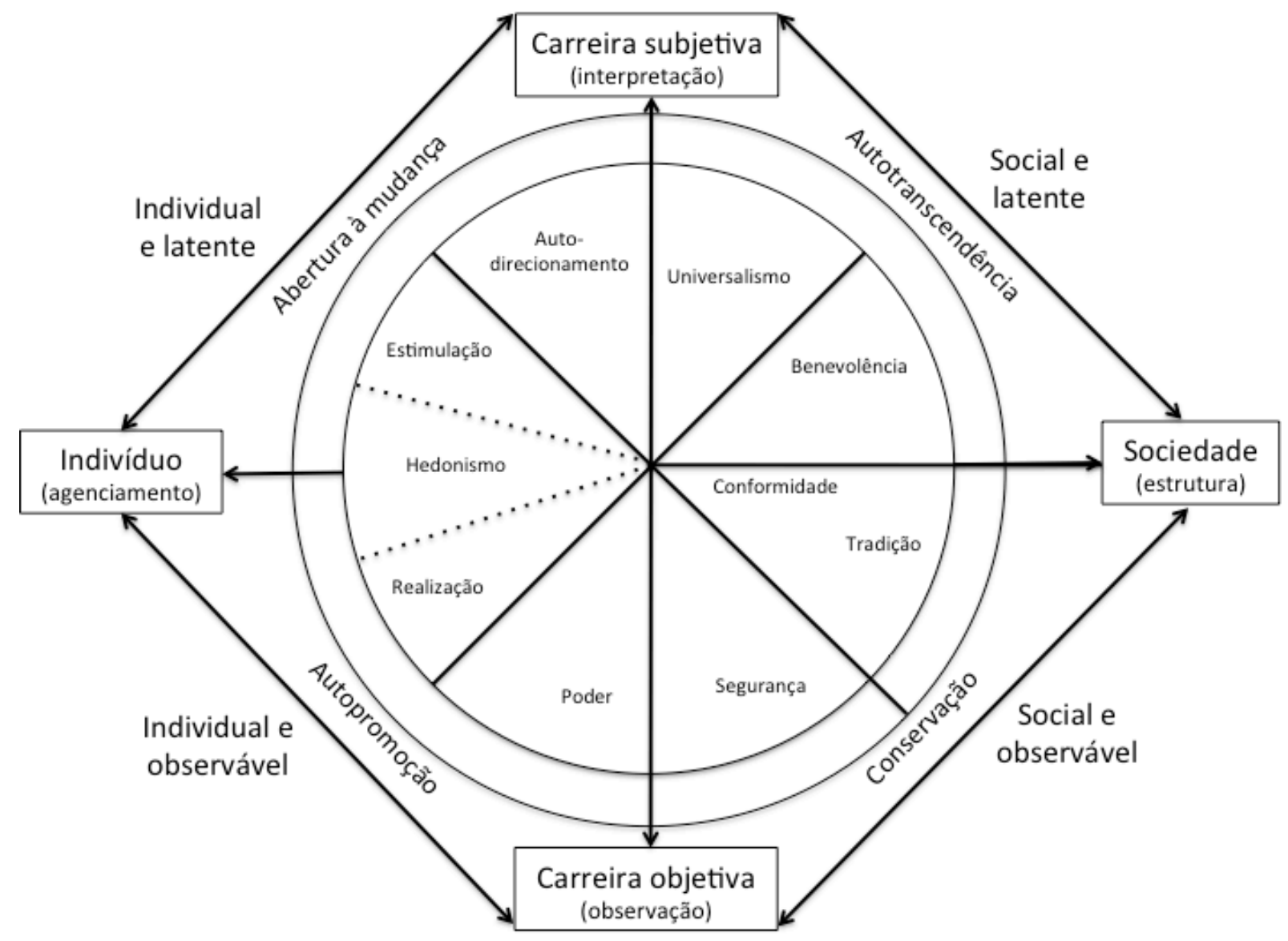

Figura 3 - Sobreposição da estrutura do sistema de valores e de critérios de avaliação do sucesso na carreira.

Fonte: Elaborado pela autora.

Ao se retomar a descrição da Figura 1, tem-se que o indivíduo, com capacidade de realizar suas motivações por meio da ação, comporta-se de acordo com o que acredita que serão os resultados de seus atos, os quais se tornam a base para as próximas ações (GIDDENS, 2003). $\mathrm{O}$ autor pontua que tais ações são efetivadas em suas interações sociais com a utilização de recursos e de regras que restringem ou ampliam as suas oportunidades na interação. Nesse fluxo de ações, o agente vai construindo sua carreira objetivamente e a interpretando para conferir sentido à sua trajetória (HUGHES, 1937; 1958). 
No decorrer de seu processo de socialização, o indivíduo aprendeu que suas necessidades internas e, portanto, suas motivações, devem ser expressadas por comportamentos, pensamentos e sentimentos desejáveis em seu contexto para obter êxito em sua vida social (KUCZYNSKI; NAVARA, 2006).

Logo, o agente que seleciona seus modos de ação de acordo com suas motivações, considerando seus recursos e as regras de interação social e esperando determinadas consequências, o faz também conforme o seu sistema de valores, porque este lhe possibilita a seleção das ações mais desejáveis, úteis ou importantes para alcançar a satisfação de suas necessidades de uma forma adequada ao contexto social no qual está inserido.

Nesse ponto, é preciso relembrar que existem diferentes domínios motivacionais de valores que orientam os comportamentos das pessoas. Segundo Schwartz (1994), tais domínios podem ser compatíveis ou conflitantes. Assim, a busca de um deles é realizada em detrimento dos objetivos daquele que está em seu polo oposto.

Portanto, quando o respondente priorizar valores de abertura à mudança, que encampa os valores de pensar e agir de forma independente, é provável que enfatize critérios de sucesso na carreira do quadrante intrapessoal-afeto, como denominado por Dries et al (2008) e definido como os sentimentos e percepções do próprio indivíduo sobre a sua carreira.

Em oposição, indivíduos que pontuarem mais alto em valores de conservação, direcionados à obtenção da segurança e à manutenção do status quo, devem ressaltar critérios do quadrante interpessoal-realização, definido pela trajetória factual de carreira socialmente validada.

Pessoas cujos valores ressaltem a autotranscendência, com motivadores de aceitação e cuidado com bem estar dos outros, estarão mais propensas a salientar critérios do quadrante interpessoal-afeto, voltado para os sentimentos e percepções do indivíduo em suas relações com outras pessoas e com as instituições nas quais sua carreira se desenvolve.

Por fim, aqueles que apresentam valores de autopromoção, visando o próprio sucesso e domínio sobre os outros, devem preferir critérios do quadrante intrapessoal-realização, conceituado como as conquistas factuais de carreira valorizadas pelo indivíduo. 


\section{A METODOLOGIA}

O presente capítulo se destina a apresentar os procedimentos metodológicos para o alcance do objetivo do estudo. Aspectos ligados à estratégia de pesquisa, aos métodos e às técnicas utilizadas serão detalhados a partir dos seguintes tópicos: variáveis do modelo conceitual de sucesso na carreira e valores pessoais para análise, o tipo de abordagem da pesquisa, a definição da população e da amostra, os instrumentos e os procedimentos de coleta de informações e, por fim, as técnicas utilizadas para análise dos dados.

\subsection{Variáveis do modelo conceitual de sucesso na carreira e valores pessoais}

Para responder à pergunta que constitui o problema de pesquisa, isto é, "existe correlação entre os valores individuais e os critérios, subjetivos e objetivos, que as pessoas utilizam para avaliar o seu próprio sucesso na carreira?", o presente estudo buscou averiguar se os valores individuais e os critérios, objetivos e subjetivos, que as pessoas usam para verificar seu próprio sucesso na carreira estão associados.

Considerando-se (1) que a carreira é uma sequência evolutiva de experiências de trabalho vivenciadas por uma pessoa ao longo do tempo (ARTHUR et al, 1989) e que no movimento entre sequências de ofícios é que o indivíduo encontra seu lugar dentro das instituições sociais e interpreta o significado de sua vida (HUGHES, 1958); (2) que os critérios de sucesso na carreira são aspectos a partir dos quais é possível avaliar se as consequências obtidas ao longo das trajetórias de carreira foram positivas (HESLIN, 2005) e; (3) que valores estão presentes sempre que pessoas julgam algumas formas de agir, pensar ou sentir como mais desejáveis, úteis ou importantes do que outras para adequarem as suas necessidades internas à vida social de forma bem sucedida (KUCZYNSKI; NAVARA, 2006), é plausível sugerir que os valores pessoais e os critérios de sucesso na carreira estejam associados.

Como salientam Gunz et al (2007) e Patton (2000), os valores são potencialmente capazes de orientar a escolha dos critérios pelos quais as pessoas aferem se estão alcançando o sucesso em suas carreiras. Assim, esses são os dois construtos a serem levantados e correlacionados nesta pesquisa. 
Os valores individuais são conceituados como objetivos transituacionais desejáveis, que variam em importância e servem como princípios orientadores na vida de uma pessoa (SCHWARTZ, 1994). O modelo de valores pessoais de Schwartz, como já exposto, apresenta duas dimensões motivacionais bipolares que delimitam um sistema de dez valores humanos.

A primeira díade corresponde à abertura à mudança (entre os eixos individual e crescimento) versus conservação (entre os eixos coletivo e defesa) - na qual os valores motivados pelo pensamento e pela ação independentes se opõem aos que tendem à preservação do status quo. A seguinte é composta por autotranscendência (entre os eixos coletivo e crescimento) versus autopromoção (entre os eixos individual e defesa) - na qual os valores que enfatizam a aceitação dos outros como iguais e a preocupação com o seu bem estar contrastam os valores que dão prioridade à busca do próprio sucesso e do domínio sobre os outros.

O sucesso na carreira, para este estudo, é definido como a conquista de resultados desejáveis de carreira, factuais ou percebidos, em algum ponto das experiências de trabalho de uma pessoa ao longo do tempo.

Como anteriormente apresentado, a pesquisa de Dries et al (2008) encontrou que os critérios de sucesso na carreira estão dispostos em quatro quadrantes, denominados: (1) interpessoalrealização, realizações factuais de carreira validadas pelo mundo externo ao indivíduo; (2) intrapessoal-realização, realizações factuais de carreira validadas pelo próprio indivíduo; (3) intrapessoal-afeto, sentimentos e percepções sobre a carreira validados pelo indivíduo ; e (4) interpessoal-afeto, sentimentos e percepções sobre a carreira validados pelo mundo externo ao indivíduo.

A sobreposição dos modelos a partir das definições de suas dimensões (Quadro 3) gerou a proposição de que valores de abertura à mudança estarão relacionados à ênfase nos critérios de sucesso na carreira do quadrante intrapessoal-afeto; valores de conservação devem se associar aos critérios do quadrante interpessoal-realização; valores de autotranscendência apresentarão relações com critérios do quadrante interpessoal-afeto; e valores de autopromoção estarão associados a critérios do quadrante intrapessoal-realização. 
Quadro 3 - Dimensões constitutivas da estrutura do sistema de valores e de critérios de avaliação do sucesso na carreira.

\begin{tabular}{|l|l|l|}
\hline Dimensão & Valores individuais & Sucesso na carreira \\
\hline $\begin{array}{l}\text { Latente e Social - não } \\
\text { observável diretamente com } \\
\text { êfase nas relações sociais. }\end{array}$ & $\begin{array}{l}\text { Autotranscendência - } \\
\text { aceitação dos outros como } \\
\text { iguais e preocupação com o } \\
\text { seu bem estar. }\end{array}$ & $\begin{array}{l}\text { Interpessoal-afeto - Sentimentos } \\
\text { e percepções sobre a carreira } \\
\text { observadas pelo mundo externo } \\
\text { ao indivíduo. }\end{array}$ \\
\hline $\begin{array}{l}\text { Latente e Individual - não } \\
\text { observável diretamente com } \\
\text { ênfase na individualidade. }\end{array}$ & $\begin{array}{l}\text { Abertura à mudança - } \\
\text { pensamento e ação } \\
\text { independentes. }\end{array}$ & $\begin{array}{l}\text { Intrapessoal-afeto - Sentimentos } \\
\text { e percepções sobre a carreira } \\
\text { validadas pelo indivíduo. }\end{array}$ \\
\hline $\begin{array}{l}\text { Observável e Individual - } \\
\text { passível de observação com } \\
\text { ênfase na individualidade. }\end{array}$ & $\begin{array}{l}\text { Autopromoção - busca do } \\
\text { próprio sucesso e do domínio } \\
\text { sobre os outros. }\end{array}$ & $\begin{array}{l}\text { Intrapessoal-realização - } \\
\text { Realizações factuais de carreira } \\
\text { obtidas pelo próprio indivíduo. }\end{array}$ \\
\hline $\begin{array}{l}\text { Observável e Social - passível } \\
\text { de observação com ênfase nas } \\
\text { relações sociais. }\end{array}$ & $\begin{array}{l}\text { Conservação - preservação } \\
\text { do status quo. }\end{array}$ & $\begin{array}{l}\text { Interpessoal-realização - } \\
\text { Realizações factuais de carreira } \\
\text { socialmente observáveis. }\end{array}$ \\
\hline
\end{tabular}

Fonte: Elaborado pela autora

Para a consecução do objetivo principal, este estudo levantou concomitantemente valores individuais e critérios de sucesso na carreira a partir dos atributos das dimensões que constituem cada um destes construtos. Além disso, um inventário de sucesso na carreira foi construído e sua validade foi verificada.

A construção de um inventário para a mensuração dos critérios objetivos e subjetivos de sucesso na carreira para profissionais brasileiros foi necessária em função de que o único instrumento encontrado na literatura passível de adoção foi construído e validado para professores universitários brasileiros (COSTA, 2010).

Como a literatura sobre sucesso na carreira salienta, diferentes profissionais (e.g., operários, gestores, enfermeiros) se pautam em diversos critérios para avaliar seu próprio sucesso na carreira. Porque os professores representam uma população específica, com suas peculiaridades, e o estudo ora apresentado não se restringe apenas a estes, tal instrumento poderia não ser adequado a uma população mais diversificada de profissionais, justificando, portanto, o procedimento de construção e validação de um novo instrumento.

No modelo elaborado para este estudo, admite-se que o sucesso na carreira é um construto multidimensional, como sugerem Dries et al (2008) e Arthur et al (2005). Assim, a verificação da estrutura dimensional dos critérios de avaliação, objetivos e subjetivos, de sucesso na carreira é parte do processo da verificação da validade do construto mensurado pelo instrumento. 
O modelo proposto por este estudo sobrepõe os domínios e as dimensões de valores aos fatores e quadrantes constituídos pelos critérios de sucesso na carreira. Assim, examinar a adequação dos dados amostrais ao modelo bidimensional dos valores individuais é um passo necessário à observação da pertinência do objetivo desta pesquisa.

\section{$5.2 \quad$ Tipo de estudo}

Os critérios básicos para classificar tipos de pesquisa as dividem quanto aos fins e quanto aos meios (VERGARA, 2009a). Quanto aos fins, Selltiz et al (1975) afirmam que os objetivos de pesquisa podem ser agrupados em três grandes categorias: (1) estudos formuladores ou exploratórios, que pretendem dar ao pesquisador familiaridade com um fenômeno para formular um problema de pesquisa mais preciso ou novas hipóteses; (2) estudos descritivos, que servem para apresentar características de uma população, um indivíduo ou um evento ou para averiguar a frequência com que algo ocorre ou com que duas variáveis estão associadas; e (3) estudos causais, cujo foco está em verificar uma hipótese de relação causal entre variáveis.

Já Sampieri et al (2006), além de apresentarem os estudos exploratórios e causais de forma semelhante à definida por Selltiz e colaboradores, diferenciam os estudos descritivos dos correlacionais. Para os autores, os estudos descritivos procuram especificar as propriedades importantes dos indivíduos, dos grupos, das comunidades ou outro fenômeno que esteja sob análise, medindo ou avaliando aspectos, dimensões ou componentes dos fenômenos investigados.

Os estudos correlacionais têm como propósito medir o grau de relação que existe entre dois conceitos ou variáveis em um contexto particular, indicando tendências do comportamento de uma variável em relação a outra ou outras variáveis medidas, fornecendo, assim, alguma informação explicativa, ainda que parcial (SAMPIERI et al, 2006).

De acordo com tais taxonomias, este estudo pode ser classificado como descritivo e correlacional, pois sua finalidade é tanto levantar e descrever as dimensões dos critérios de sucesso na carreira utilizados pelas pessoas, quanto examinar se existe algum vínculo entre este construto e o sistema de valores individuais. 
A pesquisa também pode ser enquadrada como não experimental, em contraste com os métodos experimentais de estudo, posto que a pesquisadora não manipulou deliberadamente os construtos sob investigação, levantando e analisando os fenômenos tais como foram apresentados por seus respondentes em seu contexto (SAMPIERI et al, 2006).

No que tange ao desenho do estudo, este é transversal. A pesquisa buscou analisar o nível ou o estado das variáveis sob investigação bem como a sua relação em um dado momento no tempo (SAMPIERI et al, 2006). Conforme os autores, esse tipo de desenho se propõe a descrever a incidência e a magnitude em que se manifestam as variáveis de interesse e/ou as relações entre elas, mas sem atribuir causalidade ou verificar sua evolução no tempo.

Quanto aos meios de pesquisa, o estudo integra a pesquisa bibliográfica e de campo (VERGARA, 2009a). O levantamento de informações publicadas em periódicos acadêmicos, livros e outras fontes teve como objetivo o entendimento das variáveis envolvidas na pesquisa.

O survey, com a administração de questionário fechado, foi o método de campo (VERGARA, 2009b) e forneceu os dados para a análise da relação entre os construtos sob investigação (CRESWELL, 2009). Tal método de pesquisa consiste na interrogação direta das pessoas cujo comportamento, ideias, sentimentos, planos, crenças e características socioeconômicas se deseja conhecer (GIL, 2009; GÜNTHER, 1999).

Um questionário consiste de um conjunto de perguntas sobre um ou mais construtos que se pretende medir (SAMPIERI et al, 2006), mas não testa a habilidade do respondente, aferindo, contudo, a sua opinião, os seus interesses, os aspectos de personalidade e a informação biográfica (GÜNTHER, 1999).

Assim, o survey proporciona uma descrição quantitativa ou numérica de tendências, de atitudes ou de opiniões de uma população e, portanto, a estratégia de pesquisa deste estudo pode ser caracterizada como predominantemente quantitativa (CRESWELL, 2009).

A pesquisa quantitativa é útil quando se quer obter respostas de um grande número de indivíduos, quando estes estão geograficamente dispersos, e quando se quer fazer 
levantamentos (surveys) (VERGARA, 2009b). A autora, no entanto, atenta para o fato de que o questionário tem uma baixa taxa de respostas completas retornadas ao pesquisador.

O questionário pode conter perguntas fechadas, isto é, perguntas que contêm categorias ou alternativas de resposta definidas previamente, ou perguntas abertas, cujas respostas são fornecidas livremente pelo pesquisado (VERGARA, 2009b).

Em uma estratégia de pesquisa quantitativa, é preferível a utilização de perguntas fechadas às abertas (VERGARA, 2009b), pois são mais fáceis de codificar e de preparar para análise (GIL, 2009; SAMPIERI et al, 2006; VERGARA, 2009b). Também apresentam a vantagem de requererem menores tempo e esforço por parte dos respondentes (SAMPIERI et al, 2006).

Embora alguns autores indiquem que o questionário fechado limite a liberdade de resposta dos pesquisados (e.g., SAMPIERI et al, 2006; VERGARA, 2009b), Günther (1999) sustenta que as perguntas fechadas denotam mais respeito à opinião do respondente, uma vez que ele mesmo classifica as suas respostas como positivas, negativas ou neutras. No entanto, há a possibilidade de nenhuma categoria apresentada descrever com exatidão a resposta do pesquisado (SAMPIERI et al, 2006).

O questionário deve ser completo, para que todas as informações necessárias ao alcance dos objetivos de pesquisa sejam levantadas, mas, deve ser também parcimonioso, a fim de que não se torne exaustivo e desinteressante ao respondente (SAMPIERI et al, 2006; VERGARA, 2009a; 2009b). Sampieri et al (2006) sugerem que o tempo de resposta à pesquisa não exceda 35 minutos.

\subsection{População e amostra do estudo}

A população é definida por Kish (1995) como o agregado de elementos caracterizados em termos de conteúdo, de unidades, de extensão e de tempo. Para o alcance do objetivo deste estudo, a população a ser investigada foi definida como sendo de profissionais brasileiros graduados ou pós-graduados com pelo menos três anos de experiência laboral.

Além dos indivíduos pertencentes às relações pessoais e profissionais da pesquisadora que possuem esse perfil, alunos e ex-alunos de cursos de pós-graduação da FIA - Fundação 
Instituto de Administração cujos endereços eletrônicos constassem das bases de dados de tal instituição e estivessem ativos durante o período da coleta de dados foram contatados.

Em função da opção por utilizar a internet como meio para a coleta de dados, a amostra, ou seja, os indivíduos selecionados para responder os questionários a fim de se fazerem inferências sobre a população (KISH, 1995), foi não-probabilística. Esse tipo de amostra, conforme Sampieri et al (2006), não permite o cômputo do nível de confiança, prejudicando a generalização das inferências para a população.

\subsection{Coleta de dados e instrumentos}

Os dados coletados para este estudo devem oferecer a possibilidade de verificar relações entre os critérios objetivos e subjetivos utilizados pelos indivíduos para avaliarem sucesso na carreira e os seus sistemas de valores. Ademais, devem se prestar à validação do questionário construído para mensurar os critérios de sucesso na carreira, uma vez que os instrumentos de pesquisa devem ser válidos e precisos (PASQUALI, 2010; SAMPIERI et al, 2006; VERGARA, 2009b). Por fim, as amostras em termos de suas características sociodemográficas devem ser descritas adequadamente.

Para cumprir tais metas, este estudo foi segmentado em duas pesquisas. A primeira delas se refere à construção do inventário de sucesso na carreira, requerendo a administração conjunta de um questionário para a caracterização da amostra e da avaliação da adequação das perguntas.

A segunda pesquisa teve como finalidade averiguar as relações entre sucesso na carreira e valores pessoais. Assim, esta coleta de dados contou com a administração de um instrumento composto por critérios de sucesso na carreira, do survey de valores de Schwartz e de um questionário sobre as características sociodemográficas dos respondentes.

Para ambas as investigações, os questionários foram administrados concomitantemente e por dois períodos determinados a profissionais brasileiros via internet. Alguns sites disponibilizam ferramentas de desenvolvimento de surveys no ambiente web e também os hospedam, tais como o www.surveymonkey.com.br. Destarte, uma vez elaborados, os questionários foram desenvolvidos no ambiente eletrônico. 
Para alcançar a população-alvo, enviou-se uma mensagem aos endereços eletrônicos dos profissionais com o link do endereço web no qual os instrumentos estavam disponíveis para que os respondentes os preenchessem.

Freitas et al (2004) e Vasconcellos e Guedes (2007) afirmam que a coleta de dados via web transpõe algumas barreiras tradicionais enfrentadas por pesquisadores anteriormente. Por seu meio, economiza-se tempo de coleta de dados, minimiza-se custos de impressão e de distribuição de inventários e ultrapassa-se os limites geográficos para alcançar potenciais respondentes. Ademais, custos e tempo de digitação de dados também são eliminados, reduzindo as chances de erro no processo de sua coleta.

Para o participante da pesquisa, as potenciais vantagens estão na rapidez e no conforto com o qual ele pode responder ao inventário. Todavia, esse meio de coleta de dados apresenta os inconvenientes de impossibilitar a determinação de uma amostra probabilística (FREITAS et $a l, 2004)$ e de poder atingir apenas pessoas que tenham acesso à internet (VASCONCELLOS; GUEDES, 2007). Conforme Günther (1999) e Vasconcellos e Guedes (2007), um outro problema associado à pesquisa pela internet é a baixa taxa de respostas.

\subsubsection{Estudo 1: construção e validação do inventário de sucesso na carreira}

Pasquali (2010) segmenta os procedimentos para a elaboração de um instrumento psicológico em teóricos, experimentais e analíticos. Os procedimentos teóricos encampam a escolha do construto a ser estudado, a definição de suas dimensões e propriedades, suas acepções constitutivas e operacionais e a elaboração dos itens que culminam no instrumento piloto.

Os procedimentos experimentais incluem o planejamento da aplicação do instrumento e a coleta de dados. Por fim, os procedimentos analíticos compreendem a validação do instrumento e a especificação de sua precisão. 


\section{Procedimentos teóricos}

Para Cronbach e Meehl (1955), um construto é definido implicitamente por uma rede de associações ou de proposições na qual ele ocorre. Logo, construtos são entidades teóricas derivadas das características que variáveis comportamentais observáveis têm em comum (ANASTASI; URBINA, 2000).

Portanto, o construto é uma forma de organizar em categorias as variáveis que são úteis em explicar ou predizer comportamentos (CRONBACH, 1971). Assim, os construtos carregam significados (CRONBACH; MEEHL, 1955), pois derivam de proposições teóricas que explicam ou predizem variáveis comportamentais observáveis e mensuráveis.

Os construtos são compostos por propriedades que apresentam magnitudes, variando entre sistemas individuais diferentes ou em diferentes situações ou ocasiões (PASQUALI, 2010). São estas propriedades que devem ser mensuradas, portanto. Podem estar segmentadas em dimensões (multidimensional) ou representar apenas uma dimensão (unidimensional), dependendo de sua estrutura interna ou semântica.

Os construtos e as suas dimensões devem ter suas conceituações constitutivas, ou seja, suas concepções em termos de conceitos próprios da teoria em que eles se inserem, detalhadas clara e precisamente em termos abstratos, delimitando as fronteiras que não podem ser ultrapassadas e as que devem ser atingidas (PASQUALI, 2010).

O autor indica que após esta conceituação, é necessário que as dimensões sejam definidas operacionalmente; isto é, deve-se elaborar acepções em termos de operações concretas e comportamentos por meio dos quais o construto se expressa. É a partir destas últimas definições que os itens, tarefas unitárias e específicas, serão elaborados e, por meio dos quais, o construto será mensurado.

Para fins do presente estudo, o sucesso na carreira foi definido constitutivamente como a conquista de resultados desejáveis de carreira, factuais ou percebidos, em algum ponto das experiências de trabalho de uma pessoa ao longo do tempo. 
O construto, conforme o estudo de Dries et al (2008), apresenta duas dimensões bipolares que opõem os resultados factuais aos percebidos (realização versus afeto) e os resultados socialmente validados aos individualmente validados (interpessoal versus intrapessoal). Tais dimensões são definidas constitutiva e operacionalmente no Quadro 4, a seguir.

A estratégia adotada para definir operacionalmente as dimensões foi a leitura sistemática e posterior categorização dos itens, dos relatos e dos indicadores apresentados na literatura. Assim, o Quadro 4, também menciona os respectivos autores dos quais as operacionalizações foram extraídas. 
Quadro 4 - Definições dos critérios de avaliação do sucesso na carreira.

\begin{tabular}{|c|c|c|c|}
\hline Dimensões & Definição constitutiva & Definições operacionais & Autores \\
\hline \multirow[t]{4}{*}{$\begin{array}{l}\text { Intrapessoal - } \\
\text { realização }\end{array}$} & \multirow[t]{4}{*}{$\begin{array}{l}\text { Realizações factuais de } \\
\text { carreira obtidas pelo } \\
\text { próprio indivíduo. }\end{array}$} & $\begin{array}{l}\text { Avançar na carreira ou na } \\
\text { organização }\end{array}$ & $\begin{array}{l}\text { Boudreau et al (1999); Costa (2010); Demel et al (2012); Dries et al (2008); Friedman e } \\
\text { Greenhaus (2000); Gattiker e Larwood (1986); Greenhaus et al (1990); Hennequin (2007); } \\
\text { Lee et al (2006); Nabi (2001); Parker e Chusmir (1992); Seibert et al (2001); Sturges (1999) }\end{array}$ \\
\hline & & Obter status e poder & $\begin{array}{l}\text { Boudreau et al (1999); Dries et al (2008); Friedman e Greenhaus (2000); Hennequin (2007); } \\
\text { Lee et al (2006); Parker e Chusmir (1992); Sturges (1999) }\end{array}$ \\
\hline & & $\begin{array}{l}\text { Demonstrar competência e } \\
\text { bom desempenho }\end{array}$ & $\begin{array}{l}\text { Costa (2010); Demel et al (2012); Dries et al (2008); Dyke e Murphy (2006); Gattiker e } \\
\text { Larwood (1986); Lee et al (2006); Nabi (2002); Parker e Chusmir (1992); Sturges (1999) }\end{array}$ \\
\hline & & Obter conquistas materiais & $\begin{array}{l}\text { Boudreau et al (1999); Costa (2010); Demel et al (2012); Dyke e Murphy (2006); Friedman e } \\
\text { Greenhaus (2000); Gattiker e Larwood(1986); Hennequin (2007); Parker e Chusmir (1992); } \\
\text { Seibert et al (2001); Sturges (1999) }\end{array}$ \\
\hline \multirow[t]{5}{*}{$\begin{array}{l}\text { Intrapessoal - } \\
\text { afeto }\end{array}$} & \multirow{5}{*}{$\begin{array}{l}\text { Sentimentos e } \\
\text { percepções sobre a } \\
\text { carreira validadas pelo } \\
\text { indivíduo. }\end{array}$} & Aprender e desenvolver-se & $\begin{array}{l}\text { Costa (2010); Demel et al (2012); Dries et al (2008); Dyke e Murphy (2006); Gattiker e } \\
\text { Larwood (1986); Lee et al (2006) }\end{array}$ \\
\hline & & Ser criativo e inovador & Costa (2010); Dries et al (2008); Friedman e Greenhaus (2000); Parker e Chusmir (1992) \\
\hline & & Ter independência & Demel et al (2012); Dries et al (2008); Dyke e Murphy (2006); Friedman e Greenhaus (2000) \\
\hline & & Estar satisfeito e realizado & $\begin{array}{l}\text { Boudreau et al (1999); Demel et al (2012); Dries et al (2008); Dyke e Murphy (2006); } \\
\text { Gattiker e Larwood (1986); Greenhaus et al (1990); Hennequin (2007); Nabi (2001); Parker e } \\
\text { Chusmir (1992); Seibert et al (2001); Sturges (1999) }\end{array}$ \\
\hline & & $\begin{array}{l}\text { Ter trabalho e carreira } \\
\text { pessoalmente significativos }\end{array}$ & $\begin{array}{l}\text { Demel et al (2012); Eby et al (2003); Friedman e Greenhaus (2000); Hennequin (2007); Lee } \\
\text { et al (2006); Nabi (2001); Parker e Chusmir (1992); Sturges (1999) }\end{array}$ \\
\hline \multirow[t]{3}{*}{$\begin{array}{l}\text { Interpessoal - } \\
\text { afeto }\end{array}$} & \multirow{3}{*}{$\begin{array}{l}\text { Sentimentos e } \\
\text { percepções sobre a } \\
\text { carreira observadas pelo } \\
\text { mundo externo ao } \\
\text { indivíduo. }\end{array}$} & Ter equilíbrio na vida & $\begin{array}{l}\text { Costa (2010); Demel et al (2012); Dries et al (2008); Dyke e Murphy (2006); Friedman e } \\
\text { Greenhaus (2000); Hennequin (2007); Lee et al (2006); Parker e Chusmir (1992); Sturges } \\
\text { (1999) }\end{array}$ \\
\hline & & Ter estabilidade e segurança & $\begin{array}{l}\text { Demel et al (2012); Dries et al (2008); Dyke e Murphy (2006); Friedman e Greenhaus (2000); } \\
\text { Parker e Chusmir (1992) }\end{array}$ \\
\hline & & Ser íntegro e responsável & $\begin{array}{l}\text { Costa (2010); Demel et al (2012); Dries et al (2008); Dyke e Murphy (2006); Gattiker e } \\
\text { Larwood (1986); Nabi (2001); Parker e Chusmir (1992); Sturges (1999) }\end{array}$ \\
\hline \multirow[t]{3}{*}{$\begin{array}{l}\text { Interpessoal - } \\
\text { realização }\end{array}$} & \multirow{3}{*}{$\begin{array}{l}\text { Realizações factuais de } \\
\text { carreira socialmente } \\
\text { observáveis. }\end{array}$} & Ser reconhecido & $\begin{array}{l}\text { Demel et al (2012); Dries et al (2008); Dyke e Murphy (2006); Gattiker e Larwood (1986); } \\
\text { Hennequin (2007); Lee et al (2006); Nabi (2001); Parker e Chusmir (1992); Sturges (1999) }\end{array}$ \\
\hline & & Ter bons relacionamentos & $\begin{array}{l}\text { Costa (2010); Demel et al (2012); Dries et al (2008); Dyke e Murphy (2006); Friedman e } \\
\text { Greenhaus (2000); Gattiker e Larwood (1986); Hennequin (2007); Lee et al (2006); Nabi } \\
\text { (2001); Parker e Chusmir (1992) }\end{array}$ \\
\hline & & $\begin{array}{l}\text { Contribuir com os outros e } \\
\text { com as instituições }\end{array}$ & $\begin{array}{l}\text { Costa (2010); Demel et al (2012); Dries et al (2008); Dyke e Murphy (2006); Friedman e } \\
\text { Greenhaus (2000); Lee et al (2006); Parker e Chusmir (1992) }\end{array}$ \\
\hline
\end{tabular}

Fonte: Elaborado pela autora 
A partir das definições operacionais, são elaborados os itens do instrumento. Pasquali (2010, p. 177-179) arrola dez regras para formulá-los:

(1) critério comportamental - o item deve expressar um comportamento, não uma abstração ou construto;

(2) critério de desejabilidade ou preferência - os itens devem cobrir comportamentos aos quais ao respondente deve poder expressar concordância ou discordância;

(3) critério da simplicidade - um item deve expressar uma ideia única;

(4) critério da clareza - o item deve ser inteligível até para o estrato mais baixo da populaçãoalvo; assim, deve utilizar frases curtas, com expressões simples e inequívocas;

(5) critério de relevância - a assertiva deve ser consistente com a propriedade definida e com as outras frases que cobrem a mesma propriedade;

(6) critério da precisão - o item deve possuir uma posição definida no contínuo do atributo e ser distinto dos demais itens que cobrem o mesmo contínuo;

(7) critério da variedade - deve-se variar a linguagem, para facilitar sua diferenciação e não provocar monotonia ou cansaço no respondente;

(8) critério da modalidade - não se deve utilizar expressões extremadas tais como definitivamente, sempre, etc.;

(9) critério de tipicidade - elaborar assertivas com expressões condizentes (típicas, próprias, inerentes) ao atributo; e

(10) critério da credibilidade - o item deve ser formulado de maneira que não pareça inadequado ou despropositado.

Pasquali (2010) afirma que, para que um construto seja bem representado, é preciso aproximadamente vinte itens, exceto nos casos em que o construto é muito simples, sendo 
possível representá-lo adequadamente com cinco ou seis itens. Assim sendo, a composição de questões para a mensuração do construto sucesso na carreira foi definida como apresentada no Quadro 5.

Quadro 5 - Critérios para a avaliação do sucesso na carreira.

\begin{tabular}{|c|c|}
\hline $\begin{array}{l}\text { Definições } \\
\text { operacionais }\end{array}$ & Itens \\
\hline $\begin{array}{l}\text { Avançar na carreira ou } \\
\text { na organização }\end{array}$ & $\begin{array}{l}\text { Alcançar suas próprias metas de nível hierárquico em sua carreira. } \\
\text { Ter oportunidades de promoção e de avanço na hierarquia organizacional. } \\
\text { Progredir na carreira, mudando de uma empresa para outra. } \\
\text { Perceber que as atividades desenvolvidas aumentaram em complexidade } \\
\text { durante a carreira. } \\
\text { Ter várias oportunidades de trabalho disponíveis. } \\
\text { Estar satisfeito com as promoções que já recebeu até o momento. }\end{array}$ \\
\hline Obter status e poder & $\begin{array}{l}\text { Ter uma posição ou status profissional de prestígio. } \\
\text { Alcançar uma posição gerencial. } \\
\text { Estar em uma organização de prestígio ou que tenha produtos e serviços de } \\
\text { alta qualidade. } \\
\text { Ser capaz de exercer poder ou influência nas pessoas e nos negócios. }\end{array}$ \\
\hline $\begin{array}{l}\text { Obter conquistas } \\
\text { materiais }\end{array}$ & $\begin{array}{l}\text { Ter bens materiais; poder comprar o que desejar. } \\
\text { Ficar rico; ter um salário ou uma renda muito altos. } \\
\text { Receber aumentos salariais e outros ganhos financeiros constantemente. } \\
\text { Receber benefícios especiais, tais como presentes, descontos, bônus, etc. }\end{array}$ \\
\hline $\begin{array}{l}\text { Demonstrar } \\
\text { competência e bom } \\
\text { desempenho }\end{array}$ & $\begin{array}{l}\text { Ser bem avaliado; receber feedbacks positivos. } \\
\text { Dar o melhor de si; manter alta qualidade no trabalho. } \\
\text { Ser competente na realização das atividades profissionais; fazer um bom } \\
\text { trabalho. } \\
\text { Destacar-se; ser visto como um expert. } \\
\text { Ver os resultados de seus esforços, de seu trabalho. }\end{array}$ \\
\hline $\begin{array}{l}\text { Aprender e } \\
\text { desenvolver-se }\end{array}$ & $\begin{array}{l}\text { Ter uma experiência de vida rica. } \\
\text { Expandir seus conhecimentos; aprender constantemente. } \\
\text { Adquirir formal e informalmente habilidades. } \\
\text { Tornar-se uma pessoa melhor. } \\
\text { Permanecer motivado e direcionado para novos objetivos. }\end{array}$ \\
\hline Ser criativo e inovador & $\begin{array}{l}\text { Realizar ideias inovadoras. } \\
\text { Solucionar problemas de forma criativa na vida profissional. } \\
\text { Fazer coisas que outras pessoas não fizeram antes. }\end{array}$ \\
\hline Ter independência & $\begin{array}{l}\text { Ter independência financeira. } \\
\text { Ter o estilo de vida que deseja; fazer o que deseja. } \\
\text { Ser independente profissionalmente; ser capaz de gerenciar a própria carreira. } \\
\text { Ter autonomia para gerenciar as atividades e o tempo no trabalho. }\end{array}$ \\
\hline $\begin{array}{l}\text { Estar satisfeito e } \\
\text { realizado }\end{array}$ & $\begin{array}{l}\text { Atingir seus próprios objetivos de carreira; sentir-se realizado e feliz com sua } \\
\text { vida profissional. } \\
\text { Sentir-se pessoalmente realizado. } \\
\text { Ter um trabalho do qual se gosta; sentir prazer ao fazer o trabalho. }\end{array}$ \\
\hline $\begin{array}{l}\text { Ter trabalho e carreira } \\
\text { pessoalmente } \\
\text { significativos }\end{array}$ & $\begin{array}{l}\text { Ter uma carreira com um significado ou um propósito. } \\
\text { Ter um trabalho interessante. } \\
\text { Ter um trabalho desafiador. } \\
\text { Ter diversidade de tarefas no trabalho. } \\
\text { Poder se expressar por meio do trabalho e das conquistas. }\end{array}$ \\
\hline
\end{tabular}


Quadro 5 - Critérios para a avaliação do sucesso na carreira (continuação).

\begin{tabular}{|c|c|}
\hline $\begin{array}{l}\text { Definições } \\
\text { operacionais }\end{array}$ & Itens \\
\hline $\begin{array}{l}\text { Ter estabilidade e } \\
\text { segurança }\end{array}$ & $\begin{array}{l}\text { Ter segurança financeira para satisfazer as necessidades de si mesmo e da } \\
\text { família. } \\
\text { Experimentar estabilidade e segurança no emprego; ter estabilidade na vida } \\
\text { profissional. } \\
\text { Sentir-se tranquilo em relação ao presente e futuro. } \\
\text { Receber um salário suficiente para o sustento da família e para o lazer. }\end{array}$ \\
\hline $\begin{array}{l}\text { Ser íntegro e } \\
\text { responsável }\end{array}$ & $\begin{array}{l}\text { Cumprir sua palavra; ser comprometido. } \\
\text { Ser íntegro consigo mesmo; ser ético; seguir seus próprios valores. } \\
\text { Atender os requerimentos do trabalho. } \\
\text { Cumprir suas atribuiçoes; ser responsável e disciplinado. }\end{array}$ \\
\hline Ter equilíbrio na vida & $\begin{array}{l}\text { Ter um trabalho com carga e preocupações administráveis. } \\
\text { Ter uma vida pessoal, familiar e social feliz. } \\
\text { Ter tempo e energia para se dedicar a atividades e interesses não } \\
\text { profissionais. } \\
\text { Estar satisfeito com o equilíbrio entre a vida pessoal e a vida profissional. } \\
\text { Ter boa saúde; sentir-se bem. }\end{array}$ \\
\hline Ser reconhecido & $\begin{array}{l}\text { Sentir que as pessoas percebem que você está dando o seu melhor. } \\
\text { Ter o reconhecimento do público mais amplo; ser famoso. } \\
\text { Ter suas conquistas de carreira reconhecidas por familiares e amigos. } \\
\text { Ser reconhecido por seu valor, por suas qualidades, por seus resultados na } \\
\text { organização. } \\
\text { Ser reconhecido por clientes, supervisores, pares e outras pessoas das } \\
\text { relações de trabalho. } \\
\text { Ganhar prêmios e agradecimentos, ser selecionado pela organização para } \\
\text { comparecer a eventos. } \\
\text { Receber uma remuneração justa. }\end{array}$ \\
\hline $\begin{array}{l}\text { Ter bons } \\
\text { relacionamentos }\end{array}$ & $\begin{array}{l}\text { Ter uma boa rede de contatos profissionais. } \\
\text { Estar em um ambiente de trabalho harmonioso. } \\
\text { Obter o respeito, a aceitação e o suporte das pessoas dentro da empresa. } \\
\text { Ter um relacionamento de confiança e respeito com as pessoas com quem se } \\
\text { trabalha. } \\
\text { Interagir com outras pessoas. } \\
\text { Ter uma relação de cooperação com outras pessoas. } \\
\text { Sentir-se parte da organização. } \\
\text { Fazer parte de um time de trabalho coeso e bem sucedido. }\end{array}$ \\
\hline $\begin{array}{l}\text { Contribuir com os } \\
\text { outros e com as } \\
\text { instituições }\end{array}$ & $\begin{array}{l}\text { Fazer diferença no mundo; gerar efeitos positivos na sociedade. } \\
\text { Contribuir para o sucesso organizacional. } \\
\text { Ajudar as pessoas a crescerem, se desenvolverem e se realizarem. }\end{array}$ \\
\hline
\end{tabular}

Fonte: Elaborado pela autora

\section{Procedimentos experimentais}

Os procedimentos experimentais são constituídos por dois passos: o planejamento da aplicação e a própria coleta da informação empírica (PASQUALI, 2010). No que tange ao planejamento da aplicação do instrumento piloto, é preciso definir a amostra, as instruções do instrumento e a escala de avaliação. 
Guion (1978) e Ebel (1961) sustentam que a validade de um teste pode não ser mantida em amostras de populações com diferentes características. Assim, para a construção do inventário para a mensuração dos critérios objetivos e subjetivos de sucesso na carreira para profissionais brasileiros, uma população com características iguais às da amostra para o estudo de associação foi definida, a saber: profissionais brasileiros graduados ou pósgraduados, com três ou mais anos de experiência no mercado de trabalho.

Para alcançar a população-alvo, uma mensagem a seus endereços eletrônicos foi enviada com um link de um endereço web no qual os respondentes poderiam preencher o instrumento (Anexo 1). Um dos sites que disponibilizam ferramentas de desenvolvimento de surveys no ambiente web, o www.surveymonkey.com.br, hospedou-o.

Duas instituições apoiaram o envio de e-mails convite para a participação na pesquisa: FEAmais e Nextview People. O survey com o inventário de sucesso na carreira ficou disponível no período de novembro de 2012 a fevereiro de 2013.

O FEAmais, um programa institucional que tem por objetivo manter o relacionamento entre a FEA - Faculdade de Economia, Administração e Contabilidade da Universidade de São Paulo e seus alunos e ex-alunos, enviou o e-mail convite para aproximadamente 6.300 pessoas, sendo que uma parte destas ainda não estava no mercado de trabalho, o que inviabilizaria a participação na pesquisa.

A Nextview People, uma empresa de pesquisa sobre tendências em gestão e desenvolvimento de pessoas, divulgou a pesquisa por meio eletrônico para 4.113 profissionais do mercado brasileiro.

Para o levantamento dos critérios objetivos e subjetivos de sucesso na carreira, os 71 itens foram organizados em um survey. Inicialmente, foi aclarado o objetivo da pesquisa, indicado o tempo aproximado necessário para preencher o questionário, assegurada a confidencialidade das respostas individuais, informado um endereço eletrônico para contato com a pesquisadora e, por fim, havia um agradecimento antecipado pela colaboração do respondente (Anexo 2). 
As instruções solicitavam que o participante atribuísse a pontuação que melhor expressasse a importância que cada um dos critérios de sucesso na carreira tinha para ele como objetivos de carreira buscados em sua vida (Anexo 3). Além disso, o respondente foi orientado a conferir a nota 7 para o critério mais importante. Em seguida, ele deveria pontuar como -1 aqueles que fossem opostos aos seus. A partir de então, os outros critérios deveriam receber pontuações entre 0 (não importante) e 6 (muito importante).

Tais orientações, bem como a escala escolhida, foram replicadas do Schwartz Values Survey. Schwartz (1994) alega que optou pela avaliação em detrimento à ordenação, em seu survey, por razões metodológicas e conceituais, sendo que tais apontamentos se adequam ao instrumento de sucesso na carreira. $\mathrm{O}$ autor cita que a avaliação tem mais propriedades estatísticas úteis, permitindo, ainda, que o pesquisador use listas mais longas de itens.

A avaliação não força os respondentes a discriminar entre itens igualmente importantes ou a comparar diretamente itens que eles podem perceber como não confrontáveis. Também permite que se meçam atributos negativos, aqueles que as pessoas não desejam expressar ou promover em suas escolhas e em seus comportamentos. A avaliação, ancorada pela primeira leitura da lista completa de itens, é provavelmente um processo mental mais próximo da escolha de comportamento do que a ordenação.

Adicionalmente, apresentou-se um questionário para o levantamento de dados demográficos e de informações sobre a carreira dos participantes da pesquisa, principalmente com questões abertas, que também foram avaliadas em termos de sua adequação para fornecer as informações necessárias ao estudo correlacional (Anexo 4).

\section{Procedimentos analíticos}

Com os dados tendo sido coletados, os procedimentos analíticos, com a aplicação das técnicas estatísticas para a validação do instrumento, foram realizados.

Anastasi (1977) e Hubley e Zumbo (1996) afirmam que a validade de um instrumento é uma das questões mais importantes a ser indicada em qualquer teste psicológico. Os últimos autores ainda acrescentam que, sem a validade, as inferências de um teste se tornam sem significado. 
A validade de construto é a técnica predominante desde a década de 1970 (PASQUALI, 1998; 2002) e o centro das atenções de pesquisadores atualmente (ANASTASI; URBINA, 2000; PASQUALI, 2002).

Segundo Pasquali (2002), são várias as técnicas existentes para se trabalhar a validade de construto de um teste. Dentre elas, está a análise da representação comportamental do construto, que tem por objetivo demonstrar a adequação desta representação pelo teste por meio da análise fatorial e da análise de consistência interna.

A análise fatorial é uma técnica estatística fundamental para a psicometria, especialmente para a verificação da validade de construto de testes psicológicos (ANASTASI; URBINA, 2000; CRONBACH; MEEHL, 1955; PASQUALI, 2000). Segundo Pasquali (1999, 2002), essa técnica trabalha sobre a verificação da dimensionalidade dos construtos que estão representados nos itens.

Anastasi e Urbina (2000) apontam que essa técnica estatística analisa as interrelações dos dados comportamentais medidos ou observados. Assim, Pasquali $(2000 ; 2002)$ afirma que as intercorrelações entre um número maior de itens ou variáveis, medidas ou observadas, são explicadas pela análise fatorial como resultantes de um número menor de variáveis hipotéticas ou variáveis-fonte.

Tais variáveis hipotéticas são os construtos ou traços latentes. Portanto, Anastasi e Urbina (2000) e Cronbach (1971) sustentam que uma meta da análise fatorial é tornar a descrição do comportamento mais simples através da redução do número inicial de categorias a serem analisadas a poucos fatores comuns.

Ao reduzir um grande número de variáveis a um número menor de fatores, a análise fatorial concisamente descreve e compreende as relações entre as variáveis observadas, testando uma teoria sobre processos subjacentes ou traços latentes (ANASTASI; URBINA, 2000; CRONBACH, 1971; HAIR JR. et al, 2005; PASQUALI, 2000; TABACHNICK; FIDELL, 2007). É nesse objetivo da técnica que reside a importância de sua aplicação para a validação do inventário de sucesso na carreira. 
Anastasi e Urbina (2000) mencionam que a análise da consistência interna do teste é uma prova de homogeneidade dos itens ou dos subtestes, tendo como função a caracterização do domínio de comportamento ou do traço que constitui o teste. Os índices de consistência interna estariam contribuindo, assim, para a sua validade de construto. Cronbach e Meehl (1955) sustentam que para determinados construtos a evidência de homogeneidade dentro do teste é relevante para a sua validade.

A avaliação da precisão da consistência interna é viabilizada por intermédio do cômputo do alfa de Cronbach, que visa verificar a homogeneidade da amostra de itens do instrumento (PASQUALI, 2010).

\section{A validade do instrumento de sucesso na carreira}

Uma amostra foi usada para validar o inventário. Somente os participantes que o concluíram o questionário foram incluídos no banco de dados (72 participantes não o preencheram por completo). Além disso, quatro dos participantes não residiram até completarem 15 anos no Brasil e foram eliminados das análises. Assim, dos 353 participantes iniciais, 277 compuseram a amostra final deste estudo.

Pasquali (2010) indica que quando o pesquisador tem certeza sobre o número de fatores que o instrumento mede, a amostra deve conter um mínimo de 100 sujeitos por fator medido. No entanto, se houver dúvida sobre o número de dimensões, a amostra deve ter entre cinco e dez sujeitos para cada item do instrumento.

Assim, sendo, a rigor, seria necessário obter um mínimo de 355 respondentes e um máximo de 710 para a validação do inventário de sucesso na carreira. Todavia, Pasquali (2010) e Tabachnick e Fidell (2007) apontam que a análise fatorial pode ser realizada com 200 ou mais participantes.

Portanto, o número final de respondentes da amostra é considerado como adequado para a realização da análise fatorial, embora se tenha atingido apenas 3,9 respondentes por item. Suas características são apresentadas na Tabela 1, a seguir. 
Tabela 1 - Caracterização da amostra para validação do inventário de sucesso na carreira.

\begin{tabular}{|c|c|c|}
\hline Variáveis & $n$ & $\%$ \\
\hline \multicolumn{3}{|l|}{ Sexo } \\
\hline Masculino & 171 & $63,1 \%$ \\
\hline Feminino & 100 & $36,1 \%$ \\
\hline Não informado & 6 & $2,2 \%$ \\
\hline \multicolumn{3}{|l|}{ Idade } \\
\hline Com até 24 anos & 15 & $5,4 \%$ \\
\hline De 25 a 34 anos & 102 & $36,8 \%$ \\
\hline De 35 a 44 anos & 70 & $25,3 \%$ \\
\hline De 45 a 54 anos & 40 & $14,4 \%$ \\
\hline De 55 a 64 anos & 30 & $10,8 \%$ \\
\hline Mais de 64 anos & 14 & $5,1 \%$ \\
\hline Não informado & 6 & $2,2 \%$ \\
\hline \multicolumn{3}{|l|}{ Estado civil } \\
\hline Solteiro & 78 & $28,2 \%$ \\
\hline Casado/União estável & 183 & $66,0 \%$ \\
\hline Separado/Divorciado & 10 & $3,6 \%$ \\
\hline Não informado & 6 & $2,2 \%$ \\
\hline \multicolumn{3}{|l|}{ Tem filhos } \\
\hline$\overline{\operatorname{Sim}}$ & 130 & $46,9 \%$ \\
\hline Não & 141 & $50,9 \%$ \\
\hline Não informado & 6 & $2,2 \%$ \\
\hline \multicolumn{3}{|c|}{ Onde residiu por mais tempo até os 15 anos } \\
\hline Norte & 1 & $0,4 \%$ \\
\hline Nordeste & 8 & $2,9 \%$ \\
\hline Centro-Oeste & 9 & $3,2 \%$ \\
\hline Sul & 21 & $7,6 \%$ \\
\hline Sudeste - São Paulo & 25 & $9,0 \%$ \\
\hline São Paulo & 207 & $74,7 \%$ \\
\hline Não informado & 6 & $2,2 \%$ \\
\hline \multicolumn{3}{|l|}{ Escolaridade } \\
\hline Ensino superior & 75 & $27,0 \%$ \\
\hline Pós-graduação lato sensu & 96 & $34,7 \%$ \\
\hline Pós-graduação stricto sensu & 100 & $36,1 \%$ \\
\hline Não informado & 6 & $2,2 \%$ \\
\hline \multicolumn{3}{|l|}{ Renda bruta mensal individual } \\
\hline Até $\mathrm{R} \$ 1.830,00$ & 13 & $4,6 \%$ \\
\hline De $R \$ 1.831,00$ a $\mathrm{R} \$ 3.050,00$ & 23 & $8,3 \%$ \\
\hline De $R \$ 3.051,00$ a $R \$ 4.880,00$ & 27 & $9,7 \%$ \\
\hline De $R \$ 4.881,00$ a $R \$ 9.150,00$ & 69 & $24,9 \%$ \\
\hline De $R \$ 9.151,00$ a $R \$ 12.810,00$ & 44 & $15,9 \%$ \\
\hline Acima de $\mathrm{R} \$ 12.810,00$ & 95 & $34,3 \%$ \\
\hline Não informado & 6 & $2,2 \%$ \\
\hline
\end{tabular}


Tabela 1 - Caracterização da amostra para validação do inventário de sucesso na carreira (continuação).

\begin{tabular}{lcc}
\hline Variáveis & $\mathbf{n}$ & $\mathbf{\%}$ \\
\hline Ocupação & & \\
\hline Empresário & 20 & $7,2 \%$ \\
\hline Gerente ou gestor & 121 & $43,7 \%$ \\
\hline Especialista ou analista & 77 & $27,8 \%$ \\
\hline Autônomo ou profissional liberal & 31 & $11,2 \%$ \\
\hline Outros & 22 & $7,9 \%$ \\
\hline Não informado & 6 & $2,2 \%$ \\
\hline Anos no mercado de trabalho & & \\
\hline 10 anos ou menos & 68 & $24,5 \%$ \\
\hline De 11 a 20 anos & 88 & $31,8 \%$ \\
\hline De 21 a 30 anos & 58 & $20,9 \%$ \\
\hline Mais de 30 anos & 57 & $20,6 \%$ \\
\hline Não informado & 6 & $2,2 \%$ \\
\hline Fo Da
\end{tabular}

Fonte: Dados processados.

A amostra caracterizou-se por uma predominância de respondentes do sexo masculino $(63,1 \%)$, uma concentração de pessoas com idades entre 25 a 44 anos $(62,1 \%$; média $=40,2$; desvio padrão $=12,4)$, casadas $(66 \%)$, sem filhos $(50,9 \%)$ e tendo residido no estado de São Paulo por mais tempo até completarem 15 anos de idade (74,7\%). Quanto à escolaridade, $70,8 \%$ da amostra é pós-graduada. A renda bruta mensal de 50,2\% dos participantes é superior a R\$ 9.150,00 e 50,2\% dos respondentes tem um cargo de gestão. Do total de participantes, 31,8\% estão no mercado de trabalho entre 11 e 20 anos (média = 20,5 anos; desvio padrão $=13)$.

Após a descrição da amostra, análises iniciais para verificar a adequação dos dados aos pressupostos da análise fatorial foram feitas por meio do software SPSS (Statistical Package for Social Sciences), versão 20. Não foram encontrados casos omissos ${ }^{8}$ nos itens, pois esta era uma restrição imposta pelo software de coleta de dados. Nenhum dado foi substituído e as análises fatoriais foram sempre realizadas com exclusão de casos listwise.

\footnotetext{
${ }^{8}$ Casos omissos são detectados pela frequência de respostas por categoria em cada variável. É necessária uma verificação do percentual de dados perdidos e da sistematicidade ou não da omissão (HAIR JR. et al, 2005). Os autores indicam que dados sistematicamente omitidos podem ser objeto da decisão de eliminar o sujeito ou a variável das análises a fỉm de não comprometer a generalização dos resultados.
} 
As variáveis não atenderam ao pressuposto de normalidade ${ }^{9}$, e os resultados das transformações lineares sugeridas por Tabachnick e Fidell (2007, p. 89) se mostraram infrutíferas, refutando-se a hipótese nula do teste de Kolmogov-Smirnov de que a variável tem distribuição normal a um nível de $\mathrm{p}<0,05$.

As diferenças de assimetria das variáveis sugerem a possibilidade de relações não lineares ${ }^{10}$ para alguns de seus pares. Embora tais problemas tenham sido encontrados, Hair Jr. et al (2005) afirmam que os desvios de normalidade, homocedasticidade e linearidade não são críticos para a análise fatorial, tendo seu maior impacto na redução da intensidade das correlações observadas.

Não foi observada multicolinearidade ${ }^{11}$ excessiva entre as variáveis (a maior correlação encontrada foi de $r=0,64$ ). No entanto, uma variável (v2) foi eliminada da análise por não apresentar correlações superiores a $\mathrm{r}=|0,30|$ com nenhuma outra variável (HAIR JR. et al, 2005; TABACHNICK; FIDELL, 2007).

Por fim, o cômputo da distância Mahalanobis para verificar a presença de casos extremos ${ }^{12}$ multivariados foi procedido de acordo com a sugestão de Hair Jr. et al (2005, p. 73-76), e nenhum caso foi excluído.

Uma análise dos componentes principais foi realizada antes da análise fatorial através do método dos eixos principais para estimar o número de fatores a serem extraídos, assim como a fatorabilidade da matriz.

Os índices de fatorabilidade da matriz de correlações, embora tenham se revelado satisfatórios $(\mathrm{KMO}=0,84$; teste de esfericidade de Bartlett $\operatorname{com} \mathrm{p}<0,05 ;$ MSAs $=>0,5)$, são inapropriados porque as variáveis não apresentam distribuição normal (TABACHNICK; FIDELL, 2007).

\footnotetext{
${ }^{9}$ Normalidade é o grau de aproximação dos dados da distribuição normal que pode ser verificado pelo Teste Kolmogorov-Smirnov. Este teste calcula o nível de significância para as diferenças em relação a uma distribuição normal (HAIR Jr. et al, 2005).

${ }^{10}$ Como as correlações representam apenas a associação linear entre variáveis, os efeitos não-lineares não serão representados no valor de correlação. Isso resulta em uma subestimação da força real da relação. Conforme Hair Jr. et al (2005), a linearidade é verificada pela inspeção de diagramas de dispersão ou por análise de regressão simples ou múltipla, com o exame dos resíduos, os quais refletem a parte não explicada da variável dependente.

${ }^{11}$ Multicolinearidade é a extensão em que uma variável pode ser explicada pelas outras variáveis na análise. Ou seja, são as interrelações entre as variáveis. A maneira indicada por Hair Jr. et al (2005) de identificar a colinearidade é examinar a matriz de correlação para as variáveis independentes.

${ }^{12}$ Casos extremos são observações atípicas, ou seja, substancialmente diferentes das outras.
} 
Estas análises também permitiram verificar, através dos valores dos eigenvalues e do gráfico scree (Gráfico 1) a provável existência de seis fatores.

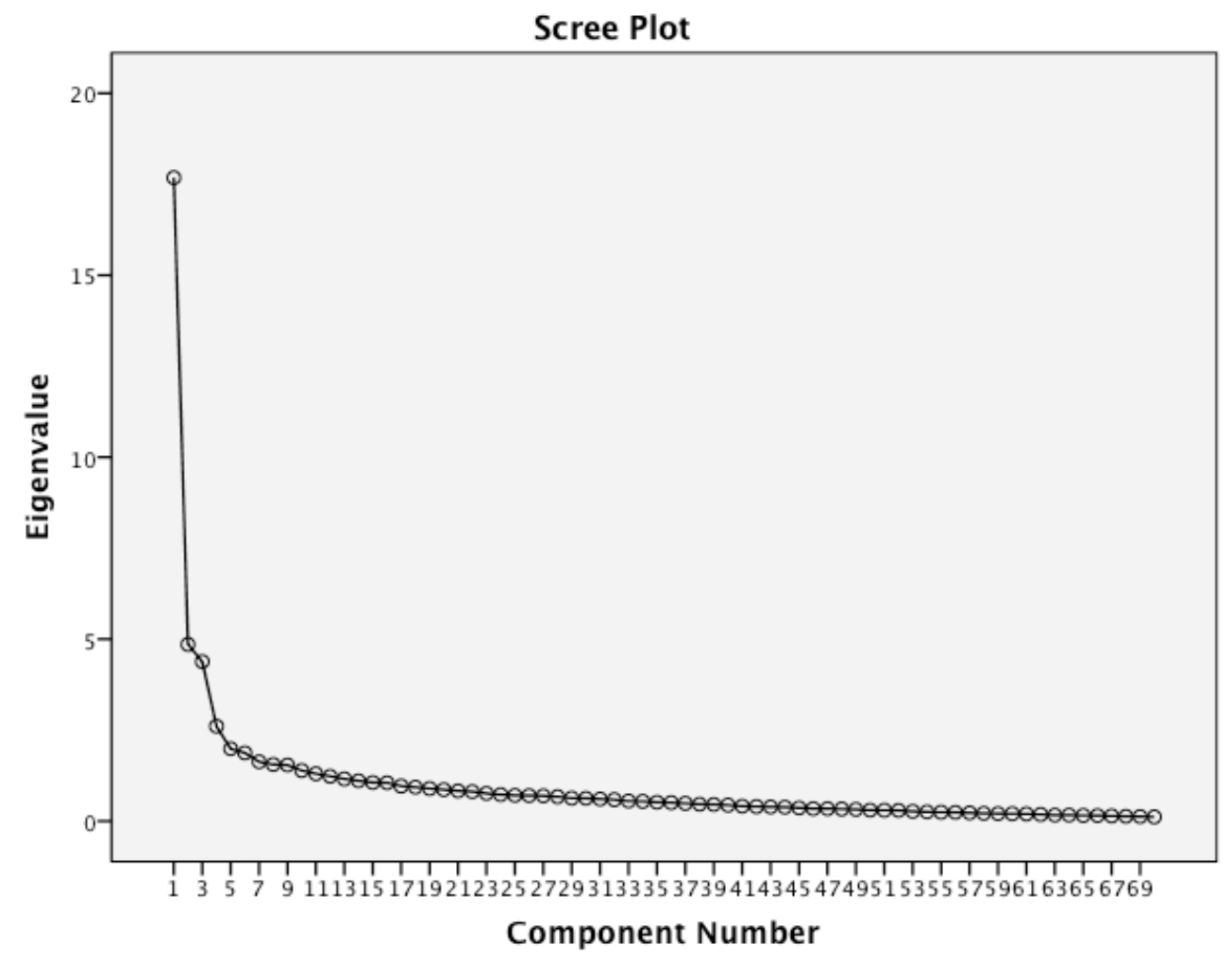

Gráfico 1 - Gráfico scree do inventário de sucesso na carreira.

Fonte: Dados processados.

Definido o número de fatores a serem extraídos, realizou-se a análise fatorial pelo método dos eixos principais com rotação varimax. O objetivo da rotação varimax é o de maximizar a variância das cargas fatoriais ao aumentar as altas cargas e reduzir as baixas para cada fator, facilitando, assim, a interpretação dos fatores, uma vez que as variáveis que se correlacionam com cada fator se tornam não ambíguas (TABACHNICK; FIDELL, 2007).

Para cada item, existe uma carga fatorial que considera apenas a relação direta de cada variável com o fator (PASQUALI, 2000; 2002). Essa carga representa a porcentagem de relação que o item tem com o fator, indicando se tal item é uma boa representação comportamental do construto (PASQUALI, 2000; 2002).

Segundo Pasquali (2010), costuma-se apontar um valor de 0,30 em módulo como sendo uma carga mínima necessária para o item ser um representante útil do fator; no entanto, são 
esperadas cargas acima de 0,50 como indicativo de que o fator foi bem representado comportamentalmente.

Ao se considerar somente itens com cargas fatoriais iguais ou superiores a 0,50 , trinta e nove variáveis não apresentaram cargas em nenhum fator. $O$ inventário de 71 itens, na solução final, constituiu-se de 32 itens, como mostra a Tabela 2. Assim, as cargas fatoriais da solução final refletiram a homogeneidade dos itens do questionário.

Tabela 2 - Fatores, comunalidades, eigenvalues, variância explicada e alfa de Cronbach do inventário de sucesso na carreira.

\begin{tabular}{|c|c|c|c|c|c|c|c|}
\hline Itens & Fator 1 & Fator 2 & Fator 3 & Fator 4 & Fator 5 & Fator 6 & Comunal. \\
\hline v27 & 0,702 & & & & & & 0,678 \\
\hline v64 & 0,652 & & & & & & 0,586 \\
\hline v61 & 0,648 & & & & & & 0,572 \\
\hline v18 & 0,580 & & & & & & 0,512 \\
\hline v60 & 0,571 & & & & & & 0,545 \\
\hline v26 & 0,561 & & & & & & 0,586 \\
\hline $\mathrm{v} 10$ & 0,558 & & & & & & 0,467 \\
\hline v28 & 0,537 & & & & & & 0,480 \\
\hline v32 & 0,537 & & & & & & 0,533 \\
\hline $\mathrm{v} 45$ & 0,527 & & & & & & 0,398 \\
\hline $\mathrm{v} 38$ & 0,526 & & & & & & 0,447 \\
\hline $\mathrm{v47}$ & & 0,694 & & & & & 0,506 \\
\hline v71 & & 0,690 & & & & & 0,638 \\
\hline v14 & & 0,561 & & & & & 0,448 \\
\hline v65 & & 0,540 & & & & & 0,458 \\
\hline v50 & & 0,532 & & & & & 0,354 \\
\hline v68 & & & 0,740 & & & & 0,568 \\
\hline v16 & & & 0,628 & & & & 0,563 \\
\hline v35 & & & 0,619 & & & & 0,542 \\
\hline v69 & & & 0,611 & & & & 0,535 \\
\hline $\mathrm{v} 41$ & & & 0,577 & & & & 0,558 \\
\hline v49 & & & & 0,761 & & & 0,536 \\
\hline v31 & & & & 0,689 & & & 0,440 \\
\hline v36 & & & & 0,584 & & & 0,403 \\
\hline v54 & & & & 0,517 & & & 0,357 \\
\hline v20 & & & & & 0,781 & & 0,641 \\
\hline $\mathrm{v} 34$ & & & & & 0,570 & & 0,571 \\
\hline v29 & & & & & 0,548 & & 0,611 \\
\hline $\mathrm{v1}$ & & & & & & 0,715 & 0,505 \\
\hline v5 & & & & & & 0,631 & 0,437 \\
\hline v19 & & & & & & 0,592 & 0,489 \\
\hline v13 & & & & & & 0,510 & 0,413 \\
\hline
\end{tabular}


Tabela 2 - Fatores, comunalidades, eigenvalues, variância explicada e alfa de Cronbach do inventário de sucesso na carreira (continuação).

\begin{tabular}{lrrrrrr}
\hline & Fator 1 & Fator 2 & Fator 3 & Fator 4 & Fator 5 & Fator 6 \\
\hline Eigenvalue & 8,106 & 2,997 & 2,775 & 1,851 & 1,636 & 1,306 \\
\hline Variância & $14,58 \%$ & $8,38 \%$ & $8,10 \%$ & $6,50 \%$ & $5,99 \%$ & $5,67 \%$ \\
\hline Alfas de Cronbach & 0,871 & 0,788 & 0,806 & 0,738 & 0,819 & 0,698 \\
\hline
\end{tabular}

Fonte: Dados processados.

A variância total do teste informa o quanto este explica do construto, sendo o restante da variância irrelevante ao conteúdo que o teste mede (como erros de medida e peculiaridades específicas dos itens), enquanto as comunalidades representam o que cada item possui de comum com os fatores, mostrando a covariância de item com os fatores (PASQUALI, 2010).

As variáveis capturadas pela solução fatorial apresentaram comunalidades com valores entre 0,36 e 0,68 , sendo que dezenove delas mostraram valores superiores a 0,5 . O percentual de variância (para um total aproximado de 49,2\%) se mostrou adequado.

Adicionalmente, computou-se o alfa de Cronbach, por averiguar a confiabilidade do instrumento de mensuração do construto com base em sua consistência interna e os resultados obtidos também se mostraram adequados.

Com seis fatores, a estrutura resultante difere da proposta de quatro dimensões. Os seis fatores encontrados foram denominados:

1. Trabalho pessoalmente significativo - Conforme Hall et al (2012), um dos motivos básicos para se trabalhar é pela própria natureza intrinsecamente gratificante da atividade laboral, cujas tarefas (interessantes, desafiadoras, variadas, com propósito), ao serem realizadas, promovem o sentimento de se estar alcançando sucesso. Assim, este fator foi composto por onze itens originários das operacionalizações ter trabalho e carreira pessoalmente significativos (3 itens), demonstrar competência e bom desempenho (3 itens), aprender e desenvolver-se ( 2 itens), estar satisfeito e realizado ( 2 itens) e contribuir com os outros e com as instituições (1 item), e exibiu a mais alta carga para a assertiva "Ter uma carreira com um significado ou um propósito."

2. Reconhecimento - Este fator foi constituído por cinco itens provenientes das operacionalizações ser reconhecido (3 itens), demonstrar competência e bom desempenho (1 
item) e obter status e poder (1 item), tendo a mais alta carga para a assertiva "Ter o reconhecimento do público mais amplo; ser famoso." O reconhecimento, por meio de agradecimentos espontâneos ou feedbacks formais relativos às tarefas desempenhadas, é um elemento importante para que o indivíduo perceba seu sucesso na carreira (HALL et al, 2012).

3. Carreira tradicional - Este fator foi composto por cinco itens oriundos das operacionalizações obter status e poder ( 2 itens), ter bons relacionamentos ( 1 item), contribuir com os outros e com as instituições (1 item) e avançar na carreira ou na organização (1 item), apresentando a mais alta carga para a assertiva "Sentir-se parte da organização." Para Hall et al (2012), os elementos do contexto de trabalho, tais como o apoio das pessoas da organização e oportunidades de mobilidade e de conquistas, são vitais para a percepção de sucesso na carreira.

4. Equilíbrio na vida - Ser capaz de equilibrar objetivos pessoais e profissionais, viver bem e ter uma boa vida são critérios de sucesso na carreira, especialmente, para indivíduos com atividades profissionais bastante demandantes (HALL et al, 2012). O fator incluiu quatro itens procedentes da operacionalização ter equilíbrio na vida, tendo sua mais alta carga para a assertiva "Estar satisfeito com o equilíbrio entre a vida pessoal e a vida profissional."

5. Inovação - Criar algo novo, ter ideias extraordinárias e ser criativo na consecução de suas tarefas (DRIES et al, 2008) podem ser consideradas formas de se destacar profissionalmente, levando a percepções de sucesso na carreira. Este fator compreendeu três itens originários da operacionalização ser criativo e inovador, apresentando a mais alta carga para a assertiva "Realizar ideias inovadoras."

6. Recompensas materiais - Como salientam Demel et al (2012), as conquistas materiais podem ser instrumentais para o suprimento de outras necessidades ou o alcance de outros objetivos. Ademais, Hall et al (2012) indicam que a fragilidade da estabilidade no emprego e insegurança financeira podem gerar sentimentos nos indivíduos de fracasso na carreira. Este fator incluiu quatro itens provenientes das operacionalizações obter conquistas materiais (2 itens), ter independência ( 1 item) e ter estabilidade e segurança (1 item), exibindo a mais alta carga para a assertiva "Ter bens materiais; poder comprar o que desejar." 
Considerados em conjunto, os resultados das análises do inventário de sucesso na carreira mostram que ele possui validade psicométrica, uma vez que seus índices estatísticos são adequados. Os fatores extraídos podem ser interpretados de acordo com a literatura sobre os critérios que as pessoas utilizam para avaliar sucesso na carreira. Assim, o inventário se apresenta válido para o alcance do objetivo deste estudo.

\subsubsection{Estudo 2: verificação da relação entre sucesso na carreira e valores pessoais}

A segunda coleta de dados, realizada entre fevereiro de 2013 e abril de 2013, administrou os dois instrumentos de levantamento - valores pessoais e sucesso na carreira -, bem como as questões de caracterização da amostra, para que o objetivo desta pesquisa fosse alcançado.

Um convite para participação na pesquisa, com o link para acesso aos questionários (Anexo 1) organizados em um survey e hospedado no site www.surveymonkey.com.br, foi enviado por mensagem aos endereços eletrônicos de profisssionais brasileiros graduados ou pós-graduados, com três ou mais anos de experiência no mercado de trabalho.

A orientadora do estudo apoiou o envio de e-mails convite, encaminhando a mensagem eletrônica para 1.082 alunos e ex-alunos de cursos de pós-graduação da FIA - Fundação Instituto de Administração aleatoriamente selecionados a partir de uma lista disponibilizada pela Fundação. A pesquisadora, por sua vez, encaminhou o convite para 235 profissionais de suas relações pessoais.

Para o levantamento dos critérios objetivos e subjetivos de sucesso na carreira e dos valores individuais, o Schwartz Values Survey e o inventário de sucesso na carreira, bem como questões de caracterização dos respondentes, foram desenvolvidos na ferramenta online já citada de surveys.

Inicialmente, explicitou-se o objetivo da pesquisa. Apresentou-se uma estimativa do tempo aproximado necessário para preencher o survey e a confidencialidade das respostas individuais foi assegurada. Além disso, forneceu-se um endereço eletrônico para contato com a pesquisadora. Por fim, agradeceu-se antecipadamente a colaboração do respondente (Anexo $5)$. 
Para a obtenção dos resultados sobre valores individuais, utilizou-se a escala de valores humanos de Schwartz (Anexo 6). O SVS (Schwartz Values Survey) apresenta 57 itens selecionados a priori para representar dez construtos motivacionais de valores distintos. Cada um dos valores listados é seguido, entre parênteses, por uma breve frase que pretende clarificar e restringir seus significados.

Este instrumento requer que os respondentes avaliem a importância de valores abstratos como princípios orientadores em suas vidas, apresentados fora do contexto. Sua medição é estruturada em escala ordinal, em que o pesquisado atribui valores inteiros entre 0 (não importante) e 6 (muito importante) segundo os seus critérios de valores preferenciais, após ancorar as suas avaliações para os valores opostos aos seus (-1) e para os de suprema importância (7).

Posteriormente, computam-se índices de preferência para cada tipo de valor ao se calcular a média das avaliações de importância a valores específicos representativos de cada domínio motivacional. Também pode-se calcular índices para as dimensões a partir das médias das pontuações individuais atribuídas aos valores que as constituem.

Para o levantamento dos critérios objetivos e subjetivos de sucesso na carreira, o inventário, com 32 assertivas, validado para profissionais brasileiros foi administrado simultaneamente aos respondentes. As seis dimensões encontradas em sua estrutura foram denominadas como apresentado no Quadro 6:

Quadro 6 - Fatores e número de itens do inventário de sucesso na carreira.

\begin{tabular}{|l|c|l|}
\hline Fatores & Itens (N) & Item mais representativo do fator \\
\hline $\begin{array}{l}\text { Trabalho pessoalmente } \\
\text { significativo }\end{array}$ & 11 & Ter uma carreira com um significado ou um propósito. \\
\hline Reconhecimento & 5 & Ter o reconhecimento do público mais amplo; ser famoso. \\
\hline Carreira tradicional & 5 & Sentir-se parte da organização. \\
\hline Equilíbrio na vida & 4 & $\begin{array}{l}\text { Estar satisfeito com o equilíbrio entre a vida pessoal e a } \\
\text { vida profissional. }\end{array}$ \\
\hline Inovação & 3 & Realizar ideias inovadoras. \\
\hline Recompensas materiais & 4 & Ter bens materiais; poder comprar o que desejar. \\
\hline
\end{tabular}

Fonte: Elaborado pela autora

Solicitou-se nas instruções que o participante atribuísse a pontuação que melhor expressasse a importância de cada um dos critérios de sucesso na carreira para si como objetivos de carreira buscados em sua vida (Anexo 3). A questão apresentada pelo inventário para orientar as 
respostas dos participantes foi: "O que é ter sucesso na carreira PARA MIM, como objetivos de carreira que eu busco em MINHA VIDA?".

O respondente tinha que conferir a nota 7 para o critério mais importante. Em seguida, ele deveria pontuar como -1 aqueles que fossem opostos aos seus. A partir de então, os outros critérios receberiam pontuações entre 0 (não importante) a 6 (muito importante).

Por fim, um questionário para o levantamento de dados demográficos e de informações sobre a carreira, tais como sexo, ano de nascimento, estado civil, número de filhos, nível de escolaridade, tempo de experiência profissional, ocupação e renda mensal bruta, foi apresentado aos participantes da pesquisa (Anexo 7). Este foi constituído por 19 questões fechadas de escolha forçada em sua maior parte. As categorias das questões foram definidas a partir dos dados encontrados no primeiro estudo.

\subsection{Técnicas selecionadas para a análise de dados}

De um ponto de vista conceitual, as técnicas de análise de dados devem ser selecionadas de acordo com o tipo de relação entre as variáveis que está sendo examinado, isto é, se é uma relação de dependência ou de interdependência. Nas relações de dependência se prevê que uma variável ou um conjunto delas tenha a capacidade de predizer o comportamento de outras variáveis, enquanto nas relações de interdependência, as variáveis são analisadas conjuntamente em um esforço para encontrar uma estrutura subjacente a elas (HAIR JR. et al, 2005).

Como este estudo não propõe a predição do comportamento de um conjunto de variáveis a partir de outro, as técnicas de interdependência são as mais adequadas ao propósito da pesquisa. Dentre essas está o escalonamento multidimensional.

A expressão escalonamento multidimensional (MDS) se refere a uma série de técnicas utilizadas para identificar dimensões de traços latentes que afetam o comportamento e que estão subjacentes às avaliações de indivíduos sobre objetos, ajudando a identificar o número e a importância relativa dessas dimensões (HAIR JR. et al, 2005). 
São procedimentos de redução de dados que computam coordenadas para um conjunto de pontos em um espaço de forma que as distâncias entre pares de pontos se adequem o mais proximamente possível às medidas de dissimilaridades obtidas dos respondentes entre os objetos (WILKINSON, 2000). Assim, conforme Hair Jr. et al (2005), o mapa perceptual resultante mostra a posição relativa de todos os objetos incluídos no procedimento.

Schwartz (2011) afirma que o escalonamento multidimensional é a técnica estatística que mais fielmente representa a ideia de um continuum motivacional de seu modelo. Quanto mais conceitualmente similares duas variáveis são, mais proximamente se posicionarão no mapa perceptual (SCHWARTZ; BILSKY, 1990; SCHWARTZ, 1994).

Hair Jr. et al (2005) informam que essa é uma técnica comparável à análise fatorial em relação ao objetivo de se definir uma estrutura dimensional subjacente. Todavia, os autores salientam que o MDS permite que se compute uma solução para cada indivíduo, o que a análise fatorial não possibilita.

Usualmente, mas não necessariamente, tal técnica pode adequar um modelo apropriado com menos dimensões do que a análise fatorial (WILKINSON, 2000). Assim, o MDS proporciona a verificação da dimensionalidade do construtos sob investigação.

Observa-se, portanto, que o escalonamento multidimensional é uma técnica apropriada para averiguar a adequação dos dados obtidos à estrutura de valores individuais, para verificar dimensionalidade subjacente aos critérios de sucesso na carreira e para analisar a proximidade entre os domínios de valores e os fatores de sucesso na carreira.

A análise das associações entre os dois construtos proposta pela pesquisa, por sua vez, deve ser realizada por meio do cômputo das correlações entre os domínios de um e os fatores do outro.

Correlações indicam a direção e a força das relações entre duas variáveis, assumindo valores entre -1 e 1 . Quanto mais perto de 1 ou -1 , maior a intensidade da relação. A direção é observada pelo sinal que, se negativo, apresenta uma relação inversa e, se positivo, apresenta uma associação direta. Ou seja, indica se quando o valor de uma variável cresce o valor da outra variável cresce também ou diminui. 
No entanto, não são medidas de causalidade; de forma que alterações um uma variável não necessariamente provocarão alterações na outra variável (ANDERSON et al, 2006). Assim, correlações são úteis para verificar se duas variáveis estão associadas de forma direta ou inversa e em que intensidade.

O Quadro 7 apresenta a relação entre as análises do estudo, as técnicas selecionadas e os resultados esperados.

Quadro 7 - Téenicas estatísticas aplicadas.

\begin{tabular}{|l|l|l|}
\hline Análises do estudo & Técnica & Resultados Esperados \\
\hline $\begin{array}{l}\text { Observar se os dados da } \\
\text { pesquisa se adequam a } \\
\text { estrutura dimensional dos } \\
\text { valores individuais. }\end{array}$ & $\begin{array}{l}\text { Escalonamento } \\
\text { multidimensional } \\
(M D S) .\end{array}$ & $\begin{array}{l}\text { Constatar as duas dimensões bipolares } \\
\text { propostas pela literatura de forma que os } \\
\text { domínios de valores individuais estejam } \\
\text { apropriadamente alocados. }\end{array}$ \\
\hline $\begin{array}{l}\text { Averiguar a estrutura } \\
\text { dimensional dos critérios } \\
\text { de avaliação, objetivos e } \\
\text { subjetivos, de sucesso na } \\
\text { carreira. }\end{array}$ & $\begin{array}{l}\text { Escalonamento } \\
\text { multidimensional } \\
(M D S) .\end{array}$ & $\begin{array}{l}\text { Averiguar se as dimensões dos critérios de } \\
\text { avaliação de sucesso na carreira apresentam } \\
\text { estruturas condizentes às obtidas pela análise } \\
\text { fatorial. Espera-se que os critérios se } \\
\text { estruturem em duas dimensões bipolares. }\end{array}$ \\
\hline $\begin{array}{l}\text { Verificar a relação entre os } \\
\text { valores individuais e os } \\
\text { critérios de avaliação, } \\
\text { objetivos e subjetivos, de } \\
\text { sucesso na carreira. }\end{array}$ & $\begin{array}{l}\text { Correlações } \\
\text { bivariadas. }\end{array}$ & $\begin{array}{l}\text { Investigar a intensidade e a direção das } \\
\text { correlações entre as dimensões dos valores } \\
\text { individuais e do sucesso na carreira. Espera-se } \\
\text { que o quadrante de abertura à mudança se } \\
\text { associe ao quadrante afeto-intrapessoal; o de } \\
\text { conservação ao realização-interpessoal; o de } \\
\text { autotranscendência ao afeto-interpessoal; e o } \\
\text { de autopromoção ao realização-intrapessoal. }\end{array}$ \\
\hline $\begin{array}{l}\text { Examinar a proximidade } \\
\text { entre os valores individuais } \\
\text { e os critérios de sucesso na } \\
\text { carreira. }\end{array}$ & $\begin{array}{l}\text { Escalonamento } \\
\text { multidimensional } \\
(M D S) .\end{array}$ & $\begin{array}{l}\text { Observar a similaridade entre as dimensões } \\
\text { dos valores individuais e do sucesso na } \\
\text { carreira. Espera-se que o domínio de abertura à } \\
\text { mudança esteja próximo dos fatores relativos } \\
\text { ao afeto-intrapessoal; o de conservação ao } \\
\text { realização-interpessoal; o de } \\
\text { autotranscendência ao afeto-interpessoal; e o } \\
\text { de autopromoção ao realização-intrapessoal. }\end{array}$ \\
\hline
\end{tabular}

Fonte: Elaborado pela autora.

Conforme Hair Jr. et al (2005), para verificar se os dados atendem aos pressupostos das técnicas, um exame prévio dos dados costuma ser realizado.

O escalonamento multidimensional, contudo, não possui como premissa a determinação de um número mínimo amostral, pois não é baseado na inferência estatística dos valores ou das relações entre variáveis de uma população e as de uma amostra aleatória extraída daquela 
população (HAIR JR. et al, 2005). Ademais, os autores informam que a técnica não tem outras suposições restritivas quanto ao comportamento das variáveis. Assim, análises preliminares não são necessárias para sua aplicação. 


\section{OS RESULTADOS}

Este capítulo se destina a apresentar os resultados da pesquisa, respondendo à questão "existe correlação entre os valores individuais e os critérios, subjetivos e objetivos, que as pessoas utilizam para avaliar o seu próprio sucesso na carreira?"

Para isto, alguns passos analíticos foram seguidos, ordenando a apresentação dos resultados:

1. Descreveu-se as características da amostra do estudo;

2. Observou-se a adequação dos dados da amostra ao modelo de sistema de valores individuais proposto por Schwartz (1994);

3. Investigou-se a estrutura dimensional dos critérios de sucesso na carreira utilizados por profissionais brasileiros; e, por fim,

4. Verificou-se as correlações e a proximidade entre os domínios de valores individuais e os fatores de sucesso na carreira.

\subsection{Caracterização da amostra}

A amostra não-probabilística se consistiu de 173 profissionais brasileiros graduados ou pósgraduados com pelo menos três anos de experiência laboral, de um total de 1.082 alunos e exalunos de cursos de pós-graduação da FIA - Fundação Instituto de Administração aleatoriamente selecionados a partir de uma lista disponibilizada pela Fundação e de 235 profissionais das relações pessoais da pesquisadora.

Portanto, obteve-se um índice de respostas de aproximadamente $13,15 \%$ do total de indivíduos contatados por e-mail. Esse baixo índice de respostas em pesquisas pela internet é uma das desvantagens apontada por Günther (1999) e Vasconcellos e Guedes (2007).

Para cada uma das análises, exclusões diferenciadas foram realizadas a partir do total de respostas obtidas. Em todas as análises, o único respondente que não havia residido no Brasil 
até completar 15 anos foi eliminado, pois Kuczynski e Navara (2007) e Schwartz e Bardi (1997) afirmam que os valores individuais adotados em uma determinada cultura permanecem relativamente estáveis após a adolescência.

Não foram encontrados casos omissos ${ }^{13}$ nos itens, pois essa era uma restrição imposta pelo software de coleta de dados, e portanto, não houve a necessidade de substituição de dados. Contudo, 16 respondentes não completaram o Schwartz Values Survey, sendo eliminados das análises da adequação dos dados ao modelo de valores individuais e das verificações das correlações e da proximidade entre valores individuais e sucesso na carreira.

Schwartz (2005) orienta que respondentes que atribuem a pontuação 7 para mais de $35 \%$ dos itens ou qualquer outra pontuação para mais de $60 \%$ dos itens devem ser excluídos das análises. Segundo o autor, a concentração de respostas pode indicar desinteresse por parte do respondente em realizar a tarefa.

Assim, foram excluídos 23 respondentes da observação da adequação dos dados ao modelo de valores individuais; 35 da investigação da estrutura dimensional de sucesso na carreira; e 32 da verificação das correlações e da proximidade entre valores individuais e sucesso na carreira.

Os subgrupos da amostra válida resultaram em 133 indivíduos para a observação da adequação dos dados ao modelo de valores individuais; em 137 respondentes para a investigação da estrutura dimensional de sucesso na carreira; e em 124 participantes para a verificação das correlações e da proximidade entre valores individuais e sucesso na carreira.

As principais características das amostras válidas para as análises podem ser observadas na Tabela 3.

\footnotetext{
${ }^{13}$ Casos omissos são detectados pela frequência de respostas por categoria em cada variável. É necessária uma verificação do percentual de dados perdidos e da sistematicidade ou não da omissão (HAIR JR. et al, 2005). Os autores indicam que dados sistematicamente omitidos podem ser objeto da decisão de eliminar o sujeito ou a variável das análises a fim de não comprometer a generalização dos resultados.
} 
Tabela 3 - Caracterização da amostra do estudo.

\begin{tabular}{|c|c|c|c|c|c|c|}
\hline \multirow[b]{2}{*}{ Variáveis } & \multicolumn{2}{|c|}{$\begin{array}{c}\text { Dimensões de } \\
\text { valores }\end{array}$} & \multicolumn{2}{|c|}{$\begin{array}{c}\text { Dimensões de } \\
\text { sucesso }\end{array}$} & \multicolumn{2}{|c|}{$\begin{array}{l}\text { Associação e } \\
\text { proximidade }\end{array}$} \\
\hline & $\bar{n}$ & $\%$ & $\bar{n}$ & $\%$ & $\bar{n}$ & $\%$ \\
\hline \multicolumn{7}{|l|}{ Sexo } \\
\hline Masculino & 60 & $45,1 \%$ & 55 & $40,1 \%$ & 54 & $43,6 \%$ \\
\hline Feminino & 70 & $52,6 \%$ & 70 & $51,1 \%$ & 67 & $54,0 \%$ \\
\hline Não informado & 3 & $2,3 \%$ & 12 & $8,8 \%$ & 3 & $2,4 \%$ \\
\hline \multicolumn{7}{|l|}{ Idade } \\
\hline Com até 24 anos & 2 & $1,6 \%$ & 2 & $1,5 \%$ & 2 & $1,6 \%$ \\
\hline De 25 a 34 anos & 57 & $43,1 \%$ & 59 & $43,1 \%$ & 56 & $45,2 \%$ \\
\hline De 35 a 44 anos & 40 & $30,2 \%$ & 35 & $25,5 \%$ & 35 & $28,2 \%$ \\
\hline De 45 a 54 anos & 22 & $16,0 \%$ & 20 & $14,6 \%$ & 19 & $15,3 \%$ \\
\hline De 55 a 64 anos & 9 & $6,8 \%$ & 9 & $6,6 \%$ & 9 & $7,3 \%$ \\
\hline Não informado & 3 & $2,3 \%$ & 12 & $8,8 \%$ & 3 & $2,4 \%$ \\
\hline \multicolumn{7}{|l|}{ Estado civil } \\
\hline Solteiro & 41 & $30,8 \%$ & 40 & $29,2 \%$ & 39 & $31,5 \%$ \\
\hline Casado/União estável & 76 & $57,1 \%$ & 75 & $54,7 \%$ & 72 & $58,1 \%$ \\
\hline Separado/Divorciado & 13 & $9,8 \%$ & 10 & $7,3 \%$ & 10 & $8,0 \%$ \\
\hline Não informado & 3 & $2,3 \%$ & 12 & $8,8 \%$ & 3 & $2,4 \%$ \\
\hline \multicolumn{7}{|l|}{ Tem filhos } \\
\hline Sim & 57 & $42,9 \%$ & 53 & $38,7 \%$ & 52 & $41,9 \%$ \\
\hline Não & 73 & $54,9 \%$ & 72 & $52,6 \%$ & 69 & $55,7 \%$ \\
\hline Não informado & 3 & $2,3 \%$ & 12 & $8,8 \%$ & 3 & $2,4 \%$ \\
\hline \multicolumn{7}{|c|}{ Onde residiu por mais tempo até os 15 anos } \\
\hline Norte & 1 & $0,8 \%$ & 1 & $0,7 \%$ & 1 & $0,8 \%$ \\
\hline Nordeste & 2 & $1,6 \%$ & 2 & $1,5 \%$ & 2 & $1,6 \%$ \\
\hline Centro-Oeste & 8 & $6,1 \%$ & 8 & $5,8 \%$ & 8 & $6,5 \%$ \\
\hline Sul & 14 & $10,6 \%$ & 14 & $10,2 \%$ & 13 & $10,5 \%$ \\
\hline Sudeste - São Paulo & 5 & $3,8 \%$ & 5 & $3,6 \%$ & 5 & $4,0 \%$ \\
\hline São Paulo & 93 & $69,9 \%$ & 89 & $65,0 \%$ & 86 & $69,3 \%$ \\
\hline Não informado & 10 & $7,5 \%$ & 18 & $13,1 \%$ & 9 & $7,3 \%$ \\
\hline \multicolumn{7}{|l|}{ Escolaridade } \\
\hline Ensino superior & 16 & $13,6 \%$ & 17 & $12,4 \%$ & 15 & $12,1 \%$ \\
\hline Pós-graduação lato sensu & 65 & $48,9 \%$ & 60 & $43,8 \%$ & 58 & $46,8 \%$ \\
\hline Pós-graduação stricto sensu & 49 & $37,8 \%$ & 48 & $35,0 \%$ & 48 & $38,7 \%$ \\
\hline Não informado & 3 & $2,3 \%$ & 12 & $8,8 \%$ & 3 & $2,4 \%$ \\
\hline \multicolumn{7}{|l|}{ Área de graduação } \\
\hline Administração & 40 & $30,1 \%$ & 35 & $25,5 \%$ & 36 & $29,0 \%$ \\
\hline Ciências humanas & 25 & $18,8 \%$ & 23 & $16,8 \%$ & 22 & $17,8 \%$ \\
\hline Comunicação social & 11 & $8,3 \%$ & 11 & $8,0 \%$ & 10 & $8,0 \%$ \\
\hline Engenharias & 24 & $18,0 \%$ & 23 & $16,8 \%$ & 22 & $17,8 \%$ \\
\hline Outras áreas & 12 & $9,0 \%$ & 12 & $8,8 \%$ & 13 & $10,5 \%$ \\
\hline Mais de uma área & 18 & $13,5 \%$ & 21 & $15,3 \%$ & 18 & $14,5 \%$ \\
\hline Não informado & 3 & $2,3 \%$ & 12 & $8,8 \%$ & 3 & $2,4 \%$ \\
\hline
\end{tabular}


Tabela 3 - Caracterização da amostra do estudo (continuação).

\begin{tabular}{|c|c|c|c|c|c|c|}
\hline \multirow[b]{2}{*}{ Variáveis } & \multicolumn{2}{|c|}{$\begin{array}{c}\text { Dimensões de } \\
\text { valores }\end{array}$} & \multicolumn{2}{|c|}{$\begin{array}{c}\text { Dimensões de } \\
\text { sucesso }\end{array}$} & \multicolumn{2}{|c|}{$\begin{array}{l}\text { Associação e } \\
\text { proximidade }\end{array}$} \\
\hline & $\bar{n}$ & $\%$ & $\mathbf{n}$ & $\%$ & $\mathbf{n}$ & $\%$ \\
\hline \multicolumn{7}{|l|}{ Renda bruta mensal individual } \\
\hline Até $\mathrm{R} \$ 2.034,00$ & 10 & $7,5 \%$ & 13 & $6,5 \%$ & 9 & $7,3 \%$ \\
\hline De $\mathrm{R} \$ 2.034,01$ a $\mathrm{R} \$ 3.390,00$ & 11 & $8,3 \%$ & 10 & $7,3 \%$ & 10 & $8,0 \%$ \\
\hline De R $\$ 3.390,01$ a $R \$ 5.424,00$ & 19 & $14,3 \%$ & 17 & $12,4 \%$ & 17 & $13,8 \%$ \\
\hline De $\mathrm{R} \$ 5.424,01$ a $\mathrm{R} \$ 10.170,00$ & 36 & $27,1 \%$ & 38 & $27,7 \%$ & 35 & $28,2 \%$ \\
\hline De $\mathrm{R} \$ 10.170,01$ a $\mathrm{R} \$ 14.238,00$ & 16 & $12,0 \%$ & 15 & $10,9 \%$ & 15 & $12,1 \%$ \\
\hline Acima de $\mathrm{R} \$ 14.238,00$ & 38 & $28,6 \%$ & 36 & $26,2 \%$ & 35 & $28,2 \%$ \\
\hline Não informado & 3 & $2,3 \%$ & 12 & $8,8 \%$ & 3 & $2,4 \%$ \\
\hline \multicolumn{7}{|l|}{ Ocupação } \\
\hline Empresário & 16 & $12,0 \%$ & 7 & $10,2 \%$ & 14 & $11,3 \%$ \\
\hline Gerente ou gestor & 53 & $39,8 \%$ & 49 & $35,7 \%$ & 49 & $39,5 \%$ \\
\hline Especialista ou analista & 28 & $21,1 \%$ & 30 & $21,9 \%$ & 26 & $21,0 \%$ \\
\hline Autônomo ou profissional liberal & 26 & $19,5 \%$ & 25 & $18,2 \%$ & 25 & $20,2 \%$ \\
\hline Outros & 7 & $5,4 \%$ & 22 & $5,1 \%$ & 7 & $5,6 \%$ \\
\hline Não informado & 3 & $2,3 \%$ & 12 & $8,8 \%$ & 3 & $2,4 \%$ \\
\hline \multicolumn{7}{|l|}{ Faz trabalho voluntário } \\
\hline Sim & 21 & $15,8 \%$ & 24 & $17,5 \%$ & 21 & $17,0 \%$ \\
\hline Não & 105 & $78,9 \%$ & 97 & $70,8 \%$ & 96 & $77,4 \%$ \\
\hline Não informado & 7 & $5,3 \%$ & 16 & $11,7 \%$ & 7 & $5,6 \%$ \\
\hline \multicolumn{7}{|l|}{ Anos no mercado de trabalho } \\
\hline 10 anos ou menos & 26 & $19,5 \%$ & 27 & $19,7 \%$ & 26 & $21,0 \%$ \\
\hline De 11 a 20 anos & 60 & $45,1 \%$ & 58 & $42,3 \%$ & 56 & $45,2 \%$ \\
\hline De 21 a 30 anos & 26 & $19,5 \%$ & 23 & $16,8 \%$ & 23 & $18,5 \%$ \\
\hline Mais de 30 anos & 18 & $13,5 \%$ & 17 & $12,4 \%$ & 16 & $12,9 \%$ \\
\hline Não informado & 3 & $2,3 \%$ & 12 & $8,8 \%$ & 3 & $2,4 \%$ \\
\hline Total & 133 & $100 \%$ & 137 & $100 \%$ & 124 & $100 \%$ \\
\hline
\end{tabular}

Fonte: Dados processados.

Pode-se observar que as características da amostra permaneceram semelhantes após a exclusão de casos para cada uma das análises.

A maior parte da amostra foi composta por pessoas que residiram por mais tempo até completarem 15 anos de idade no estado de São Paulo (variando de 65\% a 69,9\%).

Pouco mais da metade dos respondentes é do sexo feminino (cerca de 52\%), representando um equilíbrio entre participantes de ambos os sexos. 
As idades dos indivíduos se concentraram no grupo de 25 a 44 anos (aproximadamente 70\%), tendo como médias 37,6 anos (desvio padrão de 9,3 anos) para a análise das dimensões de valores, 37,3 anos (desvio padrão de 9,2 anos) para a análise das dimensões de sucesso na carreira e 37,3 anos (desvio padrão de 9,3 anos) para a verificação da associação e da proximidade entre os dois construtos. Tal característica indica que, em geral, o grupo é relativamente jovem.

Indivíduos casados ou em união estável (aproximadamente 55\%) se sobressaíram em relação aos grupos de solteiros e de separados ou divorciados. No que concerne a ter filhos, as amostras se mostram equilibradas, sendo que de 52,6\% a 55,7\% dos respondentes não são pais ou mães. Dentre os pais e mães, todos têm até três filhos, sendo que as frequências mais comumente observadas são de um (cerca de 38\%) ou dois (em torno de 53\%) filhos.

Quanto à escolaridade, há uma predominância de indivíduos com pós-graduação completa (variando de $78,8 \%$ a $86,7 \%$ ). Aproximadamente $27 \%$ são graduados em administração e em torno de $17 \%$ dos respondentes são graduados em ciências humanas, com a mesma proporção de graduados em engenharias.

Em relação à ocupação, gerentes ou gestores compuseram de 35,7\% a 39,8\% da amostra; especialistas ou analistas representaram de $21 \%$ a $21,9 \%$ da amostra; autônomos e profissionais liberais constituíram de $18,2 \%$ a $20,2 \%$ da amostra; enquanto empresários integraram de $10,2 \%$ a $12 \%$ da amostra. Cerca de $17 \%$ da amostra está envolvida em algum tipo de trabalho voluntário.

Do total de participantes, aproximadamente $44 \%$ está no mercado de trabalho entre 11 e 20 anos, tendo médias de 18,3 anos (desvio padrão de 9,3 anos) para a verificação da dimensionalidade de valores, de 17,9 anos (desvio padrão de 9,4 anos) para o exame da dimensionalidade de sucesso na carreira e de 17,9 anos (desvio padrão de 9,2 anos) para a análise de associação e de proximidade entre os dois construtos. A renda bruta mensal de $64,8 \%$ a $68,5 \%$ dos participantes é superior a $\mathrm{R} \$ 5.424,00$. 


\subsection{Observação da estrutura dimensional dos valores individuais}

Para verificar a adequação dos dados da amostra aos domínios motivacionais do Schwartz Values Survey foi processado o escalonamento multidimensional. Para Schwartz (2011) essa é a técnica estatística que mais fielmente representa a ideia de um continuum motivacional de seu modelo.

Hair Jr. et al (2005) salientam que o escalonamento multidimensional tem como objetivo representar julgamentos de respondentes quanto à similaridade ou à preferência em relação a objetos em distâncias dentro de um espaço multidimensional, indicando as dimensões de traços latentes que afetam o comportamento. Assim, emerge no mapa perceptual o que está subjacente às preferências por valores indicadas pelos respondentes.

Para que os dados representassem dissimilaridades entre objetos a partir de uma escala de avaliação de importância, calculou-se as médias para cada um dos dez domínios de valor e a média geral. Em seguida, foi necessário calcular as correlações parciais, com a média geral como covariante, para os dez domínios conforme a orientação do Centre for Cross Cultural Comparisons (2009).

A partir desses dados, a matriz negativa das correlações foi computada. Segundo Wilkinson (2000), a negativa da matriz de correlações entre as variáveis se aproxima do resultado obtido pela distância euclidiana.

Esta foi, então, utilizada para o processamento do modelo Proxscal ordinal com início aleatório único no software SPSS (Statistical Package for Social Sciences), versão 20.

O gráfico stress x número de dimensões (KRUSKAL, 1964) apresentou uma curvatura mais acentuada para a solução de duas dimensões, indicando que esse modelo deveria ser processado. Os índice de stress normalizado e coeficiente de Tucker obtidos para soluções de uma a quatro dimensões foram, respectivamente, de $0,05(0,98), 0,01(0,99), 0,00(1,0)$ e 0,00 $(1,0)$. 
Além disso, as pesquisas de Schwartz (1994; 2005) e de Schwartz e Bilsky (1987; 1990) indicam que este modelo apresenta duas dimensões. Portanto, uma solução bidimensional foi processada.

Os índices de adequação da solução bidimensional, de forma geral, apontaram para o bom ajuste do modelo aos dados (Tabela 4). $\mathrm{O}$ valor de $0,06 \%$ do índice stress normalizado pode ser considerado quase perfeito (KRUSKAL, 1964). O modelo final também conta para 99,45\% da dispersão, apresentando, coeficiente de Tucker de 99,73\%.

Tabela 4 - Índices de adequação do mapa perceptual dos domínios de valores individuais.

\begin{tabular}{lr}
\hline Medidas & \\
\hline Stress normalizado & 0,0055 \\
\hline Dispersão Contada (D.A.F.) & 0,9945 \\
\hline Coeficiente de Congruência de Tucker & 0,9973 \\
\hline
\end{tabular}

Fonte: Dados processados.

O mapa perceptual dos domínios de valores individuais apresentou uma estrutura circular, estando suas dimensões de acordo com a teoria de valores (SCHWARTZ; BILSKY, 1987; 1990; SCHWARTZ, 1994; 2005).

Embora as dimensões do mapa perceptual (Gráfico 2) estejam refletidas em relação à Figura $4^{14}$ que representa o modelo teórico dos autores, a comparação desses evidencia suas semelhanças.

\footnotetext{
${ }^{14}$ A Figura 4 é uma reprodução da Figura 2, anteriormente apresentada.
} 


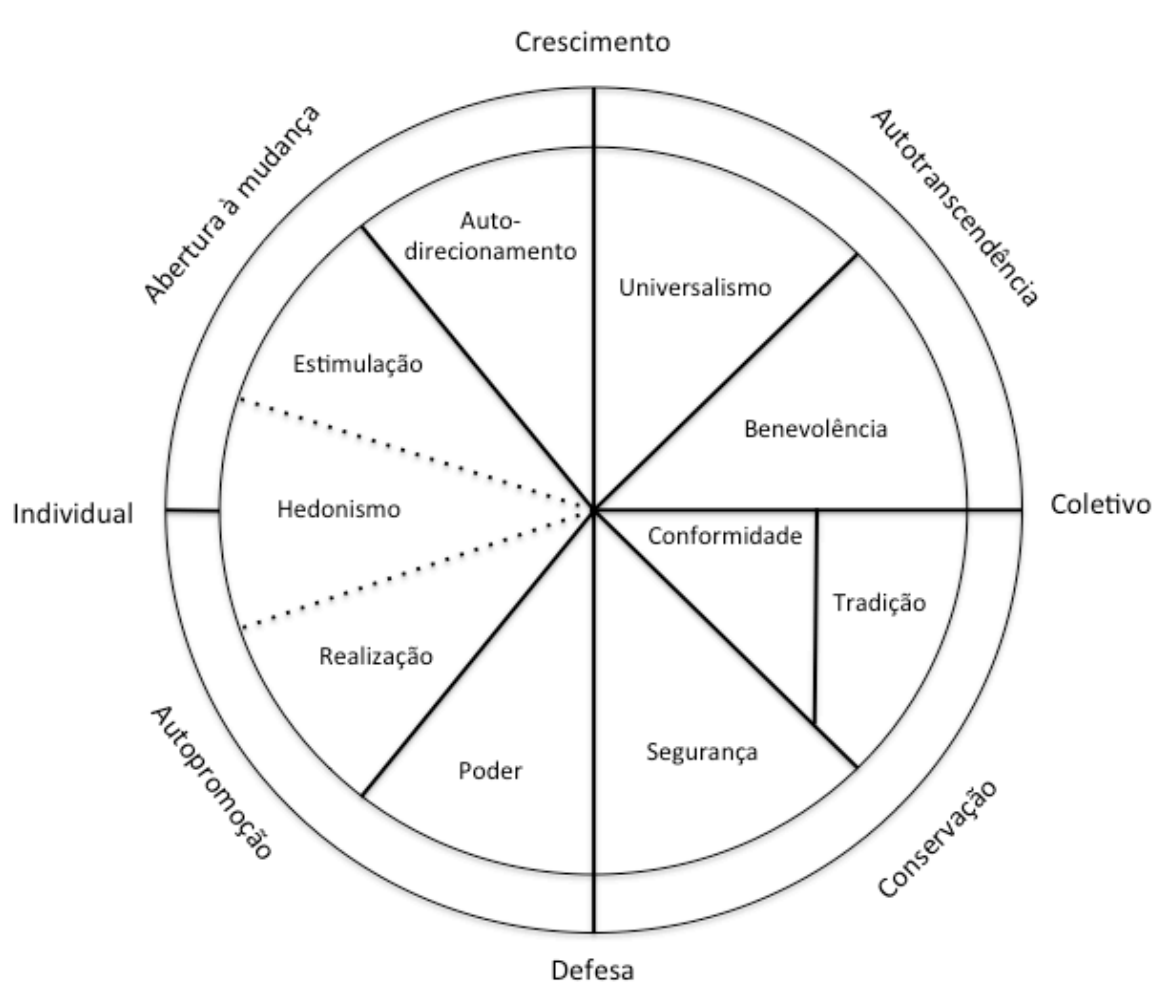

Figura 4 - Estrutura do sistema de valores.

Fonte: Adaptado de FONTAINE et al; 2008, p. 354.

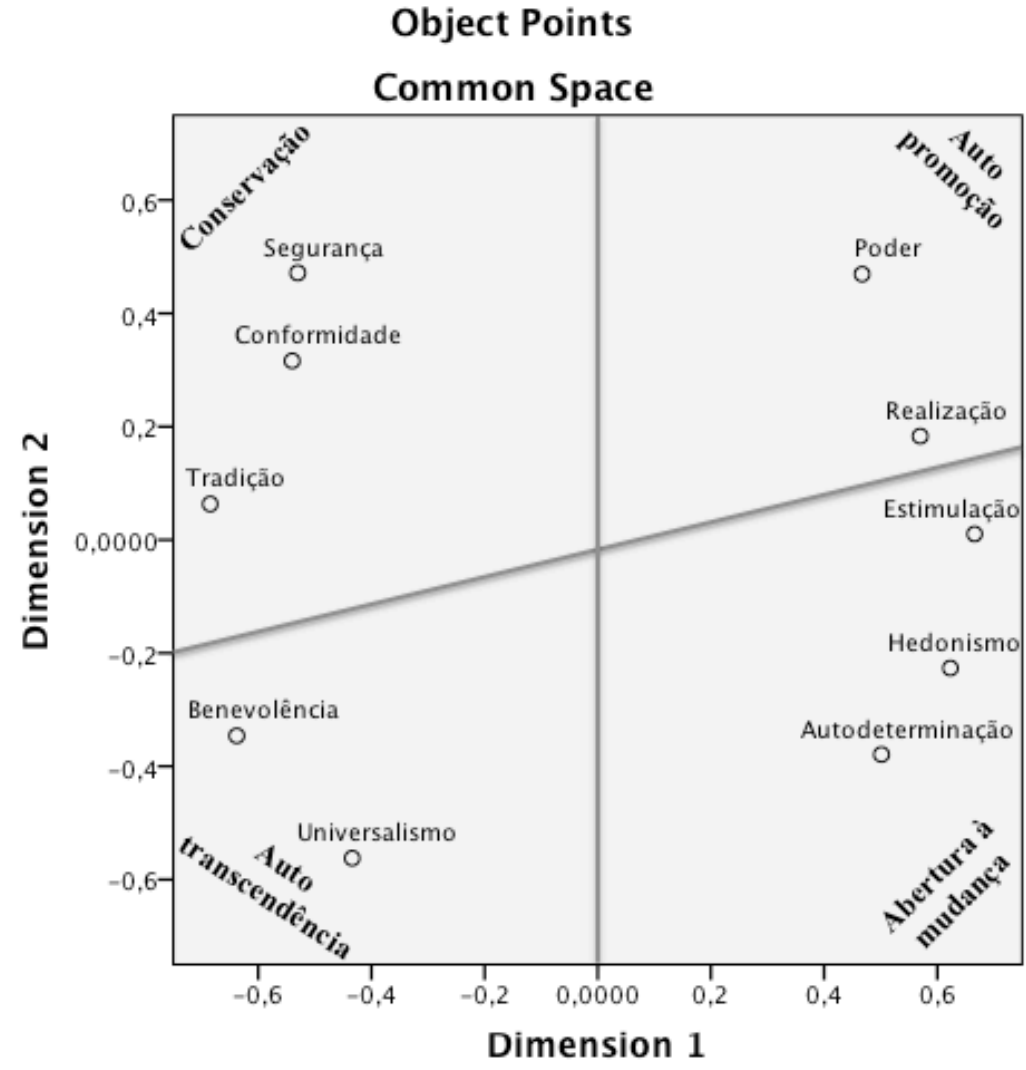

Gráfico 2 - Mapa perceptual dos domínios de valores individuais. Fonte: Dados processados. 
Como pode ser observado no Gráfico 2, a dimensão autotranscendência versus autopromoção emergiu no mapa perceptual, apresentando os domínios de universalismo e de benevolência no quadrante inferior esquerdo e os domínios de realização e poder no quadrante superior direito.

Os domínios de valores de segurança, de conformidade e de tradição se opuseram aos de estimulação, de hedonismo e de autodirecionamento; refletindo a oposição dos polos de conservação e de abertura à mudança.

A inversão dos domínios de hedonismo e de estimulação apresentada no mapa também foi encontrada por Bilsky et al (2011) para a amostra de indivíduos de Chipre em um estudo com 32 países europeus; contudo, este foi um tipo de desvio do modelo teórico considerado de menor importância pelos autores por ser uma reversão de domínios adjacentes. Assim, os dados dos domínios de valores se mostraram adequados para as análises posteriores.

O eixo horizontal apresentou as polaridades de foco coletivo (benevolência, universalismo, tradição, conformidade e segurança) e de foco individual (poder, realização, hedonismo, estimulação e autodeterminação). Conforme Fischer et al (2011), os indivíduos guiados por valores sociais são orientados para a sociedade ou relações interpessoais, enquanto as pessoas guiadas por valores pessoais são autocentradas ou tem foco intrapessoal.

Já o eixo vertical opôs defesa (conformidade, tradição, segurança e poder) e crescimento (hedonismo, estimulação, autodeterminação, universalismo e benevolência). Uma ênfase nos valores de defesa está relacionada às preocupações com sobrevivência, estabilidade pessoal e segurança (FISCHER et al, 2011). Os autores afirmam ainda que conjunto oposto de valores salienta princípios e ideias abstratos, um espírito inovador e menos dependência de bens materiais.

\subsection{Verificação da estrutura dimensional dos critérios de sucesso na carreira}

$\mathrm{O}$ escalonamento multidimensional tem como finalidade identificar dimensões subjacentes às avaliações de indivíduos sobre objetos, ajudando a identificar o número e a importância relativa dessas dimensões (HAIR JR. et al, 2005). 
Além disso, os autores informam que o escalonamento multidimensional se compara à análise fatorial no que tange à definição de uma estrutura dimensional subjacente às avaliações de preferência. Tal técnica pode ajustar um modelo apropriado com menos dimensões do que a análise fatorial (WILKINSON, 2000).

Assim, o escalonamento multidimensional é uma técnica adequada à verificação da dimensionalidade do construto sucesso na carreira. Além disso, permite que os resultados obtidos pela análise fatorial sejam verificados quanto à sua validade.

Para o processamento do escalonamento multidimensional, é necessário que os dados representem dissimilaridades entre objetos, as quais podem ser medidas diretamente ou verificadas de maneira indireta (HAIR JR. et al, 2005; WILKINSON, 2000).

Wilkinson (2000) afirma que a negativa da matriz de correlações entre as variáveis se assemelha às distâncias euclidianas. A escala de avaliação de importância dos critérios de sucesso na carreira utilizada pelos respondentes permite, portanto, apenas a obtenção de uma medida indireta de dissimilaridades.

Schwartz e Bilsky (1990) e Schwartz (1994) pontuam que quanto mais similares conceitualmente duas variáveis são, maiores as correlações entre suas avaliações de importância e mais semelhantes seus padrões de correlações com outras variáveis, emergindo, consequentemente, em maior proximidade no mapa perceptual.

Para se obter correlações adequadas para procedimentos estatísticos, o Centre for Cross Cultural Comparisons (2009) orienta que se calcule a média das pontuações individuais para o inventário, usando-as como covariantes no cômputo das correlações parciais.

Assim sendo, após a matriz de correlações parciais ter sido obtida, procedeu-se o cálculo de sua negativa, como indicado por Wilkinson (2000). A matriz negativa foi, então, utilizada como dado de entrada para cômputo do modelo Proxscal ordinal com início aleatório único no software SPSS (Statistical Package for Social Sciences), versão 20. 
Para definir o número de dimensões apropriadas para o escalonamento multidimensional, computou-se soluções para até cinco dimensões, cujos índice de stress normalizado e coeficiente de Tucker obtidos foram, respectivamente, de 0,31 (0,82), 0,06 (0,94), 0,04 (0,96), $0,02(0,98)$ e $0,01(0,99)$.

Ao se inserir os valores em um gráfico stress x número de dimensões (KRUSKAL, 1964), uma curvatura mais acentuada pode ser observada para a solução de duas dimensões, indicando que este modelo deveria ser processado.

Os índices de adequação da solução bidimensional, de forma geral, apontaram para o bom ajuste do modelo aos dados (Tabela 5). Baixos valores de stress normalizado geralmente indicam que a solução se ajusta aos dados, sendo que o valor de $6,16 \%$ pode ser considerado adequado (KRUSKAL, 1964). O modelo final também conta para 93,84\% da dispersão, apresentando, coeficiente de Tucker de 96,87\%.

Tabela 5 - Índices de adequação do mapa perceptual dos critérios de sucesso na carreira.

\begin{tabular}{ll}
\hline Medidas & \\
\hline Stress normalizado & 0,0616 \\
\hline Dispersão Contada (D.A.F.) & 0,9384 \\
\hline Coeficiente de Congruência de Tucker & 0,9687 \\
\hline
\end{tabular}

Fonte: Dados processados.

O mapa perceptual resultante é apresentado no Gráfico 2. 


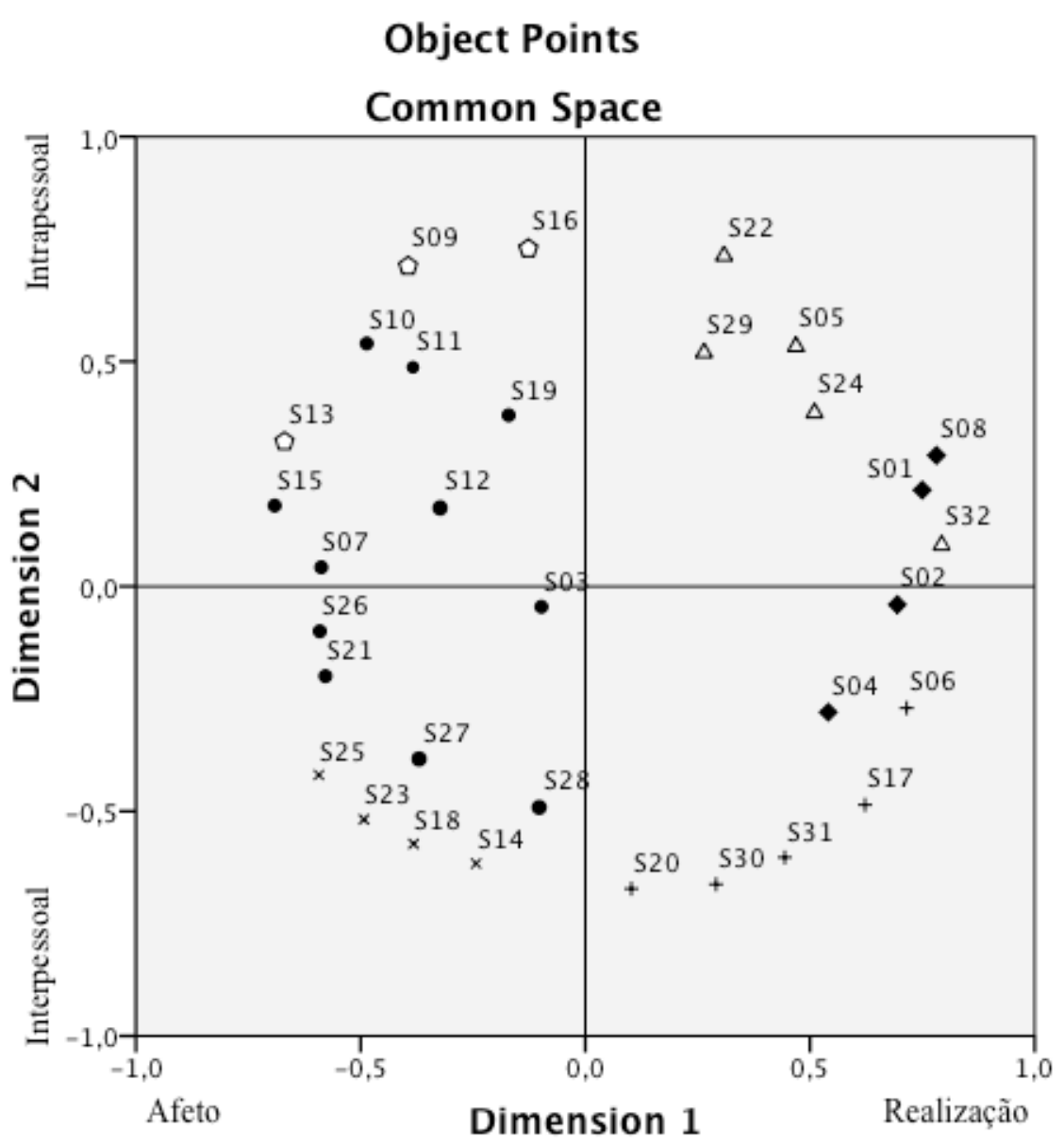

Gráfico 3 - Mapa perceptual dos critérios de sucesso na carreira.

Fonte: Dados processados.

Observa-se que os itens de carreira tradicional (marcadores em cruz) se localizaram no quadrante inferior direito do mapa perceptual, enquanto os de reconhecimento (triângulos) emergiram no quadrante superior direito. Os itens de recompensa material (losangos) formaram uma região entre estes dois quadrantes.

Já os itens de trabalho pessoalmente significativo (esferas) se intercalaram no quadrante superior esquerdo com itens de inovação (pentágonos) e no quadrante inferior esquerdo com itens de equilíbrio na vida (marcadores em $\mathrm{x}$ ).

Destarte, os itens que compuseram cada um dos fatores extraídos pela análise fatorial foram posicionados de maneira agrupada no mapa perceptual. Portanto, os resultados da análise fatorial e do escalonamento multidimensional se mostraram semelhantes. 
Entretanto, o escalonamento multidimensional apresenta uma contraposição entre grupos de itens que não foi demonstrada pela análise fatorial. $O$ mapa perceptual indica que a preferência por um grupo implica preterir o que lhe é oposto.

Arthur e Rousseau (1996), ao confrontar as características das carreiras tradicionais às das novas carreiras, fornecem explicações para isto.

Para os autores, as carreiras eram entendidas como restritas a um conjunto de trabalhadores cujas posições ocupadas mudavam ao longo do tempo com base em habilidades que eram construídas sobre as anteriores dentro de uma área específica. Tais trabalhadores recebiam recompensas institucionais, avançando em uma sequência de postos de trabalho prédeterminada. As recompensas materiais conquistadas ao longo da carreira pontuavam o que era ser um profissional de sucesso.

Contrariamente, a nova concepção implica compreender que virtualmente todos os trabalhadores possuem uma carreira, ainda que não avancem em uma estrutura hierárquica organizacional ou que seus esforços profissionais e desenvolvimento de habilidades não resultem em recompensas materiais. Nas novas carreiras, é estar atuando em um trabalho pessoalmente significativo que assinala o sucesso alcançado em suas trajetórias.

Uma outra face das carreiras tradicionais é a lealdade e o senso de pertencimento à empresa. As oportunidades de aprendizagem e de desenvolvimento de habilidades são orientadas pela gestão corporativa visando à contribuição individual ao sucesso organizacional por um lado, e à estabilidade do emprego por outro. Informação e tecnologias geradas dentro da firma permanecem ali. Assim, os laços sociais se desenvolvem e se estreitam dentro das fronteiras organizacionais. $\mathrm{O}$ sucesso profissional advém deste comprometimento do empregado com o grupo interno.

De forma oposta, as novas carreiras implicam a aceitação do risco por parte do indivíduo. Empreender, encontrar novas soluções para os problemas e novos problemas para solucionar, buscar desafios e aceitar que os fracassos são inerentes à experimentação e que contribuem ao aprendizado são características de uma carreira que está pautada em uma mobilidade entre diferentes experiências de trabalho em detrimento de em emprego estável e assegurado. 
Contudo, é exatamente essa mobilidade que possibilita o desenvolvimento de uma rede de relacionamentos sociais e profissionais mais ampla, na qual a troca de informações tem o potencial de fomentar ideias que, ao serem implementadas, podem conduzir a uma inovação bem sucedida.

A diferença entre a natureza e a amplitude dos relacionamentos desenvolvidos nas novas carreiras e nas carreiras tradicionais acima apontada endereça a última contraposição ressaltada no mapa perceptual.

O crescimento da interdependência dos indivíduos para sincronizar os trabalhos em cadeias de valor nas novas formas de organização torna saliente a necessidade de se aprender a lidar técnica, social e pessoalmente com padrões de redes de relacionamentos mais amplos, requerendo ainda um aumento no nível de conforto com a conexão. Isto eleva valores de orientação para o outro e de realizações coletivas como características do sucesso psicológico. Assim, manter um equilíbrio na vida, entre interesses e demandas profissionais, sociais, familiares e pessoais, torna-se um importante aspecto à obtenção de êxito na carreira.

Por outro lado, os indivíduos ligados à uma corporação e aos seus membros sustentavam uma crença de que seus esforços, suas contribuições e sua dedicação à empresa levariam ao reconhecimento de sua expertise, de seu mérito e de seu valor para a organização. Tal reconhecimento poderia ser aferido em termos do número de promoções, da ampliação do escopo de influência e dos crescentes aumentos salariais, reforçando o senso de autoeficácia e de sucesso.

De acordo com o que havia sido originalmente proposto, os itens de equilíbrio na vida pertenciam ao quadrante interpessoal e afeto; enquanto os itens de carreira tradicional compunham o quadrante interpessoal e realização.

Por sua vez, os itens que operacionalizaram o reconhecimento constituíam o quadrante intrapessoal e realização; enquanto os itens referentes à inovação se relacionavam ao quadrante intrapessoal e afeto. Assim, a dimensão 1 polarizou afeto e realização e a dimensão 2 , os focos intrapessoal e interpessoal. 
Logo, estes resultados apresentam evidências de que os critérios que os profissionais amostrados utilizaram para avaliar seu próprio sucesso na carreira contemplam aspectos subjetivos e objetivos. Além disso, tais critérios também apresentam um foco relacional (interpessoal) e um individual (intrapessoal).

Os aspectos subjetivo e objetivo do sucesso na carreira são destacados pela literatura (GREENHAUS, 2003). Como já mencionado, medidas de sucesso objetivo e subjetivo na carreira podem ser observadas em diversas pesquisas (e.g.; BOUDREAU et al, 1999; COSTA, 2010; GREENHAUS et al, 1990; HENNEQUIN, 2007; NABI, 2001; SEIBERT et al, 2001; STURGES, 1999).

Embora Hughes (1958), Barley (1989) e Gunz et al (2007) salientem a importância das relações sociais e das instituições, com suas oportunidades e suas limitações, no desenvolvimento de carreira das pessoas, e Giddens (2003), em sua teoria da estruturação, tenha ressaltado a dinâmica existente entre as possibilidades e as restrições da estrutura social sobre suas escolhas de ação, a dimensão que contrapõe o foco interpessoal ao intrapessoal não é mencionada pelos estudiosos do construto sucesso na carreira. Exceto pelos achados de Dries et al (2008), nenhuma outra investigação apontou esta dimensão.

Assim sendo, em consonância com Dries et al (2008) e a partir da solução ora apresentada, considerou-se que os diferentes significados atribuídos ao sucesso na carreira podem ser representados por duas dimensões bipolares.

O polo afeto é compreendido como os sentimentos e percepções que as pessoas têm sobre suas carreiras (por exemplo, perceber que seu trabalho tem um significado ou propósito ou sentir-se realizado com sua trajetória); enquanto o polo realização se refere às conquistas factuais características de suas carreiras (por exemplo, ser reconhecido como um expert em sua área de atuação ou estar financeiramente assegurado para suprir suas necessidades).

O polo intrapessoal tem seu foco no próprio ator de carreira, nas ações que ele escolhe empreender em função de seus desejos e de suas necessidades (por exemplo, ser capaz de empreender ideias inovadoras ou comprar o que desejar); enquanto o polo interpessoal salienta as relações dele com o ambiente no qual sua carreira evolui, destacando elementos 
que potencialmente reforçam ou restringem suas ações (por exemplo, experimentar um equilíbrio nas demandas que advêm da família, do trabalho e das outras relações sociais ou encontrar oportunidades de mobilidade ascendente na organização).

Em consequência, a sugestão de que o sucesso na carreira seja definido como a conquista de resultados desejáveis de carreira, factuais ou percebidos, em algum ponto das experiências de trabalho de uma pessoa ao longo do tempo recebeu apoio empírico quanto à sua pertinência para esta amostra.

Em conjunto, os resultados do escalonamento multidimensional dos dois construtos sob investigação sugerem uma possível relação entre eles. Ambos apresentam duas dimensões, sendo que uma contrapõe aspectos mais concretos (materiais e factuais) aos mais abstratos (perceptivos e afetivos) e a outra apresenta polaridades com um foco interpessoal (coletivo e relacional) e um intrapessoal (individual).

\subsection{Averiguação da associação e da proximidade entre valores pessoais e critérios de sucesso na carreira}

Correlações e correlações parciais são úteis para verificar se duas variáveis estão associadas, indicando a direção e a força de tais relações. Todavia, correlações parciais consideram também os efeitos de uma terceira variável na relação, retirando efeitos que poderiam infla-las ou subestima-las.

O modelo desta tese presume que os critérios de sucesso na carreira, pelos quais os indivíduos atribuem preferência a algumas consequências de carreira estejam associados ao seus sistemas de valores individuais, que orientam a seleção e o julgamento da desejabilidade social de determinados comportamentos, sentimentos e pensamentos.

Assim, a análise das correlações bivariadas entre os fatores de sucesso na carreira e os domínios de valores individuais é adequada para verificar a plausibilidade desta suposição.

De acordo com as orientações do Centre for Cross Cultural Comparisons (2009), a média individual total das pontuações em cada um dos inventários foi calculada. Tais médias foram 
utilizadas como covariantes para se obter as correlações parciais de Pearson entre os domínios de valores individuais e os critérios de sucesso na carreira. A matriz resultante pode ser observada na Tabela 6.

Tabela 6 - Associações entre domínios de valores individuais e critérios de sucesso na carreira.

\begin{tabular}{lrrrrrr}
\hline Domínios & $\begin{array}{c}\text { Equilíbrio } \\
\text { na vida }\end{array}$ & Inovação & $\begin{array}{c}\text { Recompensas } \\
\text { Materiais }\end{array}$ & $\begin{array}{c}\text { Carreira } \\
\text { tradicional }\end{array}$ & $\begin{array}{c}\text { Reconhe- } \\
\text { cimento }\end{array}$ & $\begin{array}{c}\text { Trabalho } \\
\text { significativo }\end{array}$ \\
\hline Autodeterm. & $-0,119$ & $0,202^{*}$ & 0,070 & $-0,334^{* *}$ & 0,017 & $0,197^{*}$ \\
\hline Benevolência & $0,225^{*}$ & $-0,008$ & $-0,299^{* *}$ & $-0,099$ & $-0,148$ & $0,332^{* *}$ \\
\hline Conformid. & $0,208^{*}$ & $-0,274^{* *}$ & $-0,058$ & $0,296^{* *}$ & $-0,126$ & $-0,073$ \\
\hline Estimulação & $-0,175$ & $0,317^{* *}$ & 0,010 & $-0,211^{*}$ & $0,188^{*}$ & $-0,081$ \\
\hline Hedonismo & 0,023 & 0,015 & $0,255^{* *}$ & $-0,071$ & $-0,054$ & $-0,104$ \\
\hline Poder & $-0,313^{* *}$ & $-0,188^{*}$ & $0,341^{* *}$ & $-0,035$ & $0,466^{* *}$ & $-0,360^{* *}$ \\
\hline Realização & $-0,297^{* *}$ & $-0,204^{*}$ & $0,256^{* *}$ & $-0,139$ & $0,356^{* *}$ & $-0,085$ \\
\hline Segurança & 0,135 & $-0,230^{*}$ & 0,082 & $0,375^{* *}$ & $-0,133$ & $-0,235^{* *}$ \\
\hline Tradição & $0,179 *$ & 0,005 & $-0,025$ & 0,146 & $-0,148$ & $-0,098$ \\
\hline Universalismo & 0,113 & $0,220^{*}$ & $-0,419^{* *}$ & 0,096 & $-0,316^{* *}$ & $0,326^{* *}$ \\
\hline
\end{tabular}

* Significante ao nível de $\mathrm{p}<0,05$.

** Significante ao nível de $\mathrm{p}<0,01$.

Fonte: Dados processados.

Do total de sessenta correlações entre domínios que representam os dois construtos sob investigação, dezenove $(31,7 \%)$ foram significativas ao nível de $\mathrm{p}<0,01$ e onze $(18,3 \%)$ ao nível de $\mathrm{p}<0,05$.

Considerando-se apenas as correlações significativas a um nível de $p<0,01$, sua média aproximada é de $r=0,319$, com um valor mínimo de $r=-0,235$ (entre segurança e trabalho pessoalmente significativo) e um valor máximo de $\mathrm{r}=0,466$ (na relação entre poder e reconhecimento). As correlações significativas a um nível de $\mathrm{p}<0,05$ têm média aproximada de $r=0,205$; variando entre $r=0,179$ (entre tradição e equilíbrio na vida) e $r=-0,230$ (na relação entre segurança e inovação).

Embora tais correlações variem de fracas a moderadas, Gandal et al (2005) encontraram correlações entre valores e tipos de orientação de carreira significativas que variaram de $r=0,19$ a $r=-0,30$. Além disso, a correlação encontrada por Orpen (1976) entre o índice de sucesso na carreira objetivo e valores foi de $\mathrm{r}=0,36$ com um nível de significância de $\mathrm{p}<0,01$. Destarte, as intensidades das associações entre valores individuais e critérios de sucesso na carreira deste estudo se mostraram de acordo com o tipo de fenômeno investigado. 
Benevolência e universalismo estão contidos no polo dimensional de valores de autotranscendência. Supôs-se que esse polo apresentasse relação direta com o quadrante interpessoal-afeto e inversa com o quadrante intrapessoal-realização. Os resultados mostraram a adequação de tal conjectura.

Benevolência se associou negativamente com recompensas materiais $(r=-0,299)$ e positivamente com trabalho pessoalmente significativo $(\mathrm{r}=0,332)$ e com equilíbrio na vida $(\mathrm{r}=0,225)$. O domínio de valor universalismo apresentou correlações significativas negativas com recompensas materiais $(r=-0,419)$ e com reconhecimento $(r=-0,316)$ e positivas com trabalho pessoalmente significativo $(r=0,326)$ e com inovação $(r=0,220)$. Inovação não pertence ao quadrante intrapessoal-afeto; entretanto, se posiciona em um quadrante contíguo (intrapessoal-realização), apresentando, ainda, menor intensidade do que as relações com trabalho pessoalmente significativo e equilíbrio na vida.

O polo dimensional de valores autopromoção é constituído pelos domínios poder, realização e hedonismo. Conjecturou-se que esse polo tivesse uma correlação positiva com o quadrante intrapessoal-realização e uma negativa com o quadrante interpessoal-afeto. As correlações observadas indicam que tal expectativa é pertinente.

O domínio de valor poder apresentou correlações significativas negativas com trabalho pessoalmente significativo $(r=-0,360)$, com equilíbrio na vida $(r=-0,313)$ e com inovação $(\mathrm{r}=-0,188)$ e positivas com reconhecimento $(\mathrm{r}=0,466)$ e com recompensas materiais $(\mathrm{r}=0,341)$. O domínio de valor realização associou-se negativamente com equilíbrio na vida $(r=-0,297)$ e com inovação $(r=-0,204)$ e positivamente com reconhecimento $(r=0,356)$ e com recompensas materiais $(r=0,256)$. Hedonismo obteve uma correlação significativa positiva com recompensas materiais $(\mathrm{r}=0,255)$.

Conformidade, segurança e tradição compõem o polo dimensional de valores de conservação. Esperava-se que esse polo apresentasse uma relação direta com o quadrante interpessoalrealização e uma inversa com o quadrante intrapessoal-afeto. O padrão de correlações obtidas sugere a adequação entre o que era esperado e o que foi observado. 
Conformidade relacionou-se negativamente com inovação $(r=-0,274)$ e positivamente com carreira tradicional $(r=0,296)$ e com equilíbrio na vida $(r=0,208)$. Segurança apresentou associações negativas com trabalho pessoalmente significativo $(r=-0,235)$ e com inovação $(\mathrm{r}=-0,230)$ e positiva com carreira tradicional $(\mathrm{r}=0,356)$. Uma correlação significativa positiva foi obtida entre tradição e equilíbrio na vida $(\mathrm{r}=0,179)$. Equilíbrio na vida não pertence ao quadrante interpessoal-realização; contudo, se localiza em um quadrante adjacente (interpessoal-afeto) e apresenta menor significância estatística do que as relações dos domínios de valores analisados com carreira tradicional.

Abertura à mudança, o polo dimensional oposto à conservação, compreende os domínios de valores de autodirecionamento, estimulação e hedonismo. Presumiu-se que esse polo revelasse uma associação positiva com o quadrante intrapessoal-afeto e uma negativa com o quadrante interpessoal-realização. Os resultados ofereceram evidências da adequação de tal suposição.

O domínio de valor autodirecionamento tem correlações positivas com os domínios de sucesso na carreira de inovação $(r=0,202)$ e de trabalho pessoalmente significativo $(r=0,197)$ e uma associação significativa negativa com carreira tradicional $(r=-0,334)$. Estimulação, por sua vez, apresentou uma relação significativa negativa com recompensas materiais $(r=-0,299)$ e associações positivas com inovação $(r=0,317)$ e com reconhecimento $(\mathrm{r}=0,188)$. Já o domínio de valor hedonismo obteve uma correlação significativa positiva com recompensas materiais $(\mathrm{r}=0,255)$. O quadrante intrapessoal-realização é constituído pelos critérios de reconhecimento e recompensas materiais e contíguo ao intrapessoal-afeto. Assim, as relações entre estes critérios e os domínios de valores analisados não são inconsistentes com o modelo proposto.

De forma geral, tais resultados indicam que o modelo proposto neste estudo representa adequadamente as relações existentes entre os valores individuais e os critérios que as pessoas utilizam para avaliar o sucesso de suas próprias carreiras.

No intuito de observar a proximidade entre os domínios de valores individuais e fatores de sucesso na carreira, as correlações foram usadas como entrada para o escalonamento multidimensional. 
Como indicado por Wilkinson (2000), foi calculada a matriz negativa das correlações parciais obtidas entre os domínios dos dois construtos. A matriz negativa foi, então, utilizada como dado de entrada para cômputo do modelo Proxscal ordinal com início aleatório único no software SPSS (Statistical Package for Social Sciences), versão 20.

Para definir o número de dimensões apropriadas para o escalonamento multidimensional, computou-se soluções para até cinco dimensões, cujos índice de stress normalizado e coeficiente de Tucker obtidos foram, respectivamente, de 0,29 (0,85), 0,02 (0,99), 0,06 (0,97), $0,01(0,99)$ e $0,00(0,99)$.

Os valores foram inseridos em um gráfico stress x número de dimensões (KRUSKAL, 1964), observando-se uma curvatura mais acentuada para a solução de duas dimensões. Assim, esse modelo foi processado.

Os índices de adequação da solução bidimensional, de forma geral, apontaram para o bom ajuste do modelo aos dados (Tabela 7). Baixos valores de stress normalizado geralmente indicam que a solução se ajusta aos dados, sendo que o valor de $1,65 \%$ pode ser considerado excelente (KRUSKAL, 1964). O modelo final também conta para 98,35\% da dispersão, apresentando coeficiente de Tucker de 99,17\%.

Tabela 7 - Índices de adequação do mapa perceptual dos domínios de valores e dos critérios de sucesso na carreira.

Fonte: Dados processados.

\begin{tabular}{lr}
\hline Medidas & \\
\hline Stress normalizado & 0,0165 \\
\hline Dispersão Contada (D.A.F.) & 0,9835 \\
\hline Coeficiente de Congruência de Tucker & 0,9917 \\
\hline
\end{tabular}

Ao se confrontar o modelo proposto nesta tese (Figura $5^{15}$ ) com o mapa perceptual resultante (Gráfico 4), é possível notar a pertinência da proposição de que a seleção de modos de ação do agente para satisfazer suas motivações em suas interações sociais que constroem sua trajetória e, portanto, de seu julgamento sobre o êxito alcançado em seu curso de carreira, está relacionada ao seu sistema de valores.

\footnotetext{
${ }^{15}$ A Figura 5 é uma reprodução da Figura 3 apresentada anteriormente.
} 




Figura 5 - Sobreposição da estrutura do sistema de valores e de critérios de avaliação do sucesso na carreira. Fonte: Elaborado pela autora.

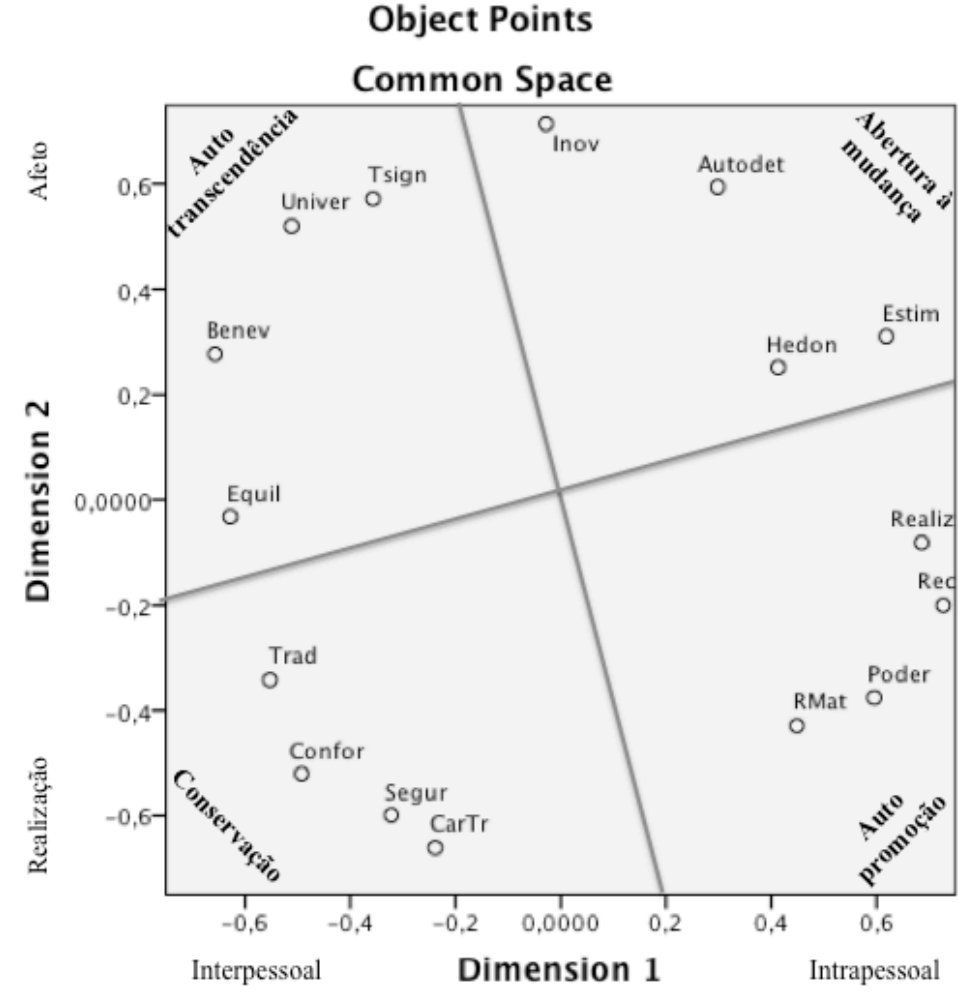

Gráfico 4 - Mapa perceptual dos domínios de valores individuais e dos critérios de sucesso na carreira. Fonte: Dados processados. 
O quadrante interpessoal-afeto conteve os critérios de sucesso na carreira de trabalho pessoalmente significativo e de equilíbrio na vida, bem como os domínios de valores universalismo e benevolência (ambos do polo dimensional de valores autotranscendência).

O quadrante intrapessoal-afeto foi composto pelo critério de inovação e pelos domínios de valores autodirecionamento, estimulação e hedonismo (do polo dimensional de valores de abertura à mudança).

O quadrante intrapessoal-realização se constituiu pelos critérios de sucesso de reconhecimento e recompensas materiais, bem como pelos domínios de poder e realização (do polo dimensional de valores autopromoção).

Por fim, o quadrante interpessoal-realização conteve o critério de carreira tradicional e os domínios de valores tradição, conformidade e segurança (do polo dimensional conservação).

Para esta amostra, o sistema de valores individuais se associa aos conjuntos de critérios utilizados pelas pessoas para julgarem se estão alcançando sucesso em suas carreiras, podendo ser representado adequadamente por distâncias em um espaço perceptual.

A representação espacial ainda demonstra a adequação da oposição entre os domínios de valores, mas também entre os conjuntos de critérios. Logo, pode-se supor que, da mesma forma que valores de um domínio são conflitantes ou compatíveis na busca pelo alcance de valores de outros domínios (SCHWARTZ, 1994), assim também são os critérios de sucesso na carreira.

Autopromoção, constituída de valores que dão prioridade à busca do próprio sucesso e do domínio sobre os outros (SCHWARTZ; BILSKY, 1987; 1990), se destina a propósitos individuais e de defesa. Portanto, a busca dos recursos materiais é motivada pela necessidade de assegurar a sobrevivência, a estabilidade e a segurança do indivíduo, controlando a ansiedade gerada pelas incertezas do contexto pela expressão de sua autonomia, reforçando, assim, seu senso de controle interno (FISCHER et al, 2011). 
Assim, os indivíduos com valores de autopromoção, ligam-se a uma corporação e nutrem crenças de que seus esforços, suas contribuições e sua dedicação à empresa levarão ao reconhecimento de sua expertise, de seu mérito e de seu valor para a organização, resultando em recompensas materiais e em um aumento do poder, tais como promoções, ampliação do escopo de influência e crescentes aumentos salariais. Tais consequências reforçam seu senso de autoeficácia e de sucesso (ARTHUR; ROUSSEAU, 1996).

Em consonância, Gandal et al (2005) levantaram que indivíduos que enfatizavam valores de autopromoção tinham orientações do tipo carreira, que salientam a necessidade de crescimento profissional, especialmente, por meio da mobilidade ascendente nas organizações.

Conservação, cujos valores tendem à preservação do status quo, enfatizando a autorrestrição, as práticas tradicionais e a proteção da estabilidade (SCHWARTZ; BILSKY, 1987; 1990), se relaciona a propósitos coletivos e de defesa. A busca da satisfação das necessidades materiais, a fim de assegurar a sobrevivência e a estabilidade do indivíduo que auxilia no controle da ansiedade gerada pelo ambiente, é realizada por meio das relações sociais que influenciam o alcance do êxito de seu esforço (FISCHER et al, 2011).

Assim, nas carreiras tradicionais, a estabilidade do emprego e a satisfação das necessidades materiais são alcançadas por meio da lealdade e do comprometimento à corporação (ARTHUR; ROUSSEAU, 1996), externalizados pelo engajamento nas oportunidades de aprendizagem que os gestores determinam, pela manutenção da confidencialidade das informações obtidas dentro das fronteiras organizacionais e pelo estreitamento dos laços com seus membros.

Autotranscendência, composta por valores que enfatizam a aceitação dos outros como iguais e a preocupação com seu bem estar (SCHWARTZ; BILSKY, 1987; 1990), está associada a propósitos coletivos e de crescimento. Necessidades de informação e de estimulação intelectual e emocional, que se revelam quando a ansiedade não está presente, são satisfeitas por meio das relações sociais e afetivas que se tem com os outros (FISCHER et al, 2011).

O crescimento da interdependência dos indivíduos para sincronizar os trabalhos em cadeias de valor ressalta a necessidade de se aprender a lidar com padrões de redes de relacionamentos 
mais amplos, elevando a importância de valores de orientação para o outro e de realizações coletivas como características do sucesso psicológico (ARTHUR; ROUSSEAU, 1996). Assim, manter um equilíbrio na vida entre interesses e demandas profissionais, sociais, familiares e pessoais se torna um importante aspecto à obtenção de êxito na carreira. Da mesma forma, atuar em um trabalho pessoalmente significativo, especialmente se compreendido em termos de contribuição para a sociedade e ajuda aos outros (GANDAL et al, 2005), reforça o senso de sucesso psicológico.

Abertura à mudança, com valores que estão ordenados com base no pensar e no agir independentemente, favorecendo a mudança (SCHWARTZ; BILSKY, 1987; 1990), endereça propósitos individuais e de crescimento. A fim de satisfazer necessidades de informação e de estimulação intelectual e emocional, o espírito inovador, a autonomia e o senso de controle interno são expressados (FISCHER et al, 2011).

O senso de controle interno e de autonomia são alcançados ao se empreender, encontrar novas soluções para os problemas e novos problemas para solucionar, buscar desafios, aceitar que os fracassos são inerentes à experimentação e que contribuem ao aprendizado e correr riscos. Tais comportamentos levam à inovação (ARTHUR; ROUSSEAU, 1996) e satisfazem as necessidades de informação e de estimulação individuais.

Considerando-se tais reflexões sobre a solução obtida por meio da técnica, pode-se sugerir que o modelo que sobrepõe as dimensões de valores e de sucesso na carreira proposto neste estudo indica que os fatores de sucesso de carreira estão orientados aos mesmos propósitos que os domínios motivacionais de valores individuais para esta amostra.

Portanto, o indivíduo, com capacidade de realizar suas motivações por meio da ação, se comporta de acordo com o que acredita que serão os resultados de seus atos (GIDDENS, 2003), mas seleciona tais comportamentos em consonância com a utilidade, a desejabilidade ou a importância destes nas situações sociais para alcançar os resultados que deseja (KUCZYNSKI; NAVARA, 2006), cuja síntese, formada ao longo do processo de socialização, constitui-se em seu sistema de valores. Tais ações são efetivadas em suas interações sociais com a utilização de recursos e de regras que restringem ou ampliam as suas oportunidades na 
interação (GIDDENS, 2003). Nesse fluxo de ações, o agente vai construindo sua carreira objetivamente e a interpretando para conferir sentido à sua trajetória (HUGHES, 1937; 1958).

É preciso ressaltar, no entanto, que as técnicas e a metodologia de pesquisa adotadas não se prestam a fazer inferências causais. Assim, não é possível afirmar que os valores individuais determinam ou influenciam quais fatores de sucesso na carreira serão usados como critérios de avaliação pelas pessoas. 


\section{CONSIDERAÇÕES FINAIS}

Mudanças ocorridas na transição do século XX para o século XIX nos cenários econômico, tecnológico e político (KANTER, 1989; STOREY, 2000) influenciaram a construção de novas estruturas nas organizações de trabalho (HALL; MIRVIS, 1996; MILES; SNOW, 1996). Além disso, alterações demográficas e culturais foram associadas à mudança na postura das pessoas em relação às suas carreiras (GREENHAUS; FOLEY, 2007; GUEST; STURGES, 2007; STOREY, 200; SULLIVAN; BARUCH, 2009; WRZESNIEWSKI, 2002).

Esse novo contexto conduziu os teóricos da área de carreiras à reavaliarem o conceito de carreira para torná-lo representativo das trajetórias atuais, mais idiossincráticas e dirigidas pelos indivíduos em vez de orientadas pelas organizações de trabalho (ARTHUR; ROUSSEAU, 1996; ARTHUR et al, 1989; HESLIN, 2005; SULLIVAN, 1999).

Assim, a carreira, tradicionalmente especificada por uma trajetória ascendente na estrutura hierárquica formal de uma organização (ARTHUR; ROUSSEAU, 1996; GUEST; STURGES, 2007; HALL, 1996; 2002; SULLIVAN; 1999), passou a ser conceituada como uma “[...] sequência evolutiva de experiências de trabalho vivenciadas por uma pessoa ao longo do tempo." ${ }^{16}$ (ARTHUR et al, 1989, p. 8).

Nessa esteira, o sucesso na carreira também teve seu foco alterado. Como apontado por Hall e Mirvis (1996), o enfraquecimento dos aspectos que apoiavam os referenciais de sucesso na carreira, tais como um emprego assegurado e uma constante escalada na pirâmide hierárquica com seus consequentes aumentos salariais e de status profissional, incitaram os indivíduos a analisar as suas ambições de carreira para encontrar outras fontes de sucesso.

De forma geral, as pesquisas têm utilizado os indicadores objetivos de sucesso característicos de uma carreira tradicional, tais como renda, proporção de aumentos salariais, número de promoções e nível do cargo ocupado (ARTHUR et al, 2005; HESLIN, 2005).

Contudo, os critérios subjetivos estão sendo cada vez mais considerados nas pesquisas sobre sucesso na carreira mais recentemente (HESLIN, 2005). Em relação ao sucesso subjetivo, os

16 “[...] evolving sequence of a person's work experiences over time.” 
indicadores mais comumente mensurados são a satisfação com o trabalho, com a carreira e com a vida (GREENHAUS, 2003; HESLIN, 2005).

Arthur et al (2005), Greenhaus (2003) e Heslin (2005), entretanto, afirmam que as pesquisas sobre sucesso na carreira devem incorporar outros indicadores. Essa ampliação é salientada porque os novos padrões de carreira estão fundamentados, em especial, nas necessidades dos indivíduos, o que requer a compreensão do que significa sucesso na carreira para eles (HALL, 2002; HESLIN, 2005).

Os estudiosos sobre carreira, assim, pontuam a necessidade de que a definição do construto sucesso na carreira seja reavaliada, tornando-a mais ampla para representar sua multidimensionalidade (e.g., ARTHUR et al, 2005; DRIES et al, 2008; GUNZ et al, 2006; HENNEQUIN, 2007; HESLIN, 2005; SULLIVAN; BARUCH, 2009).

Pesquisas qualitativas sobre o que é o sucesso na carreira apontaram uma diversidade de temas mencionados por diferentes grupos de pessoas; estes variam dos tradicionais indicadores de sucesso objetivo, tais como status profissional, recompensas financeiras, segurança no emprego e avanço na carreira, aos mais subjetivos, como, por exemplo, realização pessoal, integridade, liberdade de escolha e crescimento pessoal (e.g., DEMEL et al, 2012; DYKE; MURPHY, 2006; HENNEQUIN, 2007; STURGES, 1999).

Mayrhofer et al (2012) afirmam que essa diversidade de temas, contudo, pode ser agrupada em quatro dimensões: questões relacionadas ao indivíduo, a recompensas materiais, ao pertencimento à organização e à interação com o ambiente mais amplo.

Por sua vez, Dries et al (2008), por meio de análises estatísticas, encontraram que o construto sucesso na carreira está estruturado em duas dimensões bipolares. Uma delas se refere à oposição entre as realizações factuais de carreira e os sentimentos e percepções dos indivíduos sobre estas realizações. A outra polariza os aspectos relacionais e os individuais das consequências de carreira.

Alguns autores sugerem que as escolhas de curso de ação pelos indivíduos em suas trajetórias de carreira estejam de acordo com seus valores pessoais (e.g., GUNZ et al, 2007; HALL, 
2000; PATTON, 2000), influenciando, portanto, as consequências de carreira que são obtidas por eles.

Valores representam objetivos desejáveis, que variam em importância e servem como princípios orientadores da vida de uma pessoa (SCHWARTZ, 1994) e atribui-se a eles a capacidade de predizer atitudes e comportamentos (ROHAN, 2000). Portanto, eles estão presentes sempre que pessoas julgam algumas formas de agir, pensar ou sentir como mais desejáveis, úteis ou importantes do que outras (KUCZYNSKI; NAVARA, 2006).

Além disso, valores estão organizados em um sistema de dimensões bipolares que contrapõem, por um lado, motivadores com vistas ao alcance de objetivos individuais aos relacionais e, por outro, motivadores relacionados aos aspectos mais concretos de sobrevivência e de segurança em um polo e aos intelectuais e emocionais, no outro (SCHWARTZ, 1994).

Assim, em virtude do exposto, este estudo teve o intuito de observar se existem associações entre o sistema de valores pessoais e os conjuntos de critérios, objetivos e subjetivos, de sucesso na carreira.

Assumiu-se, nesta tese, que o construto sucesso na carreira é multidimensional, sendo estruturado por duas dimensões bipolares que opõem um foco no próprio indivíduo a um foco nos relacionamentos e os aspectos mais factuais aos aspectos mais perceptivos das consequências de carreira.

Além disso, conjecturou-se que os polos dimensionais do sucesso na carreira estariam associados aos polos dimensionais do sistema de valores individuais de forma que:

1) os propósitos intrapessoais ligados às conquistas objetivas de carreira estivessem associados à autopromoção;

2) os propósitos intrapessoais relacionados às consequências afetivas de carreira se apresentassem associados à abertura à mudança; 
3) os propósitos interpessoais relativos aos aspectos factuais de carreira se relacionassem à conservação; $\mathrm{e}$

4) os propósitos interpessoais relacionados aos afetos envolvidos na carreira se ligassem à autotranscendência.

Os resultados permitiram identificar dois aspectos importantes do construto sucesso na carreira. O primeiro deles se refere à como estrutura dimensional dos critérios de sucesso na carreira é percebida pelos indivíduos da amostra. O último, à sua relação com o sistema de valores individuais.

Os aspectos subjetivo e objetivo do sucesso na carreira destacados pela literatura (GREENHAUS, 2003) emergiram no mapa perceptual, polarizando os sentimentos e as percepções que as pessoas têm sobre suas trajetórias versus as conquistas factuais características de suas carreiras.

A segunda dimensão do construto sucesso na carreira que contrapõe o foco interpessoal ao intrapessoal não é mencionada pelos estudiosos da área, exceto pelos achados de Dries et al (2008). Tais resultados sugerem, portanto, que a dinâmica existente entre as possibilidades e as restrições da estrutura social sobre as escolhas do curso de ação do indivíduo que se direcionam à satisfação de suas necessidades em sua carreira, bem como a avaliação de suas consequências, deva ser melhor investigada por futuras pesquisas.

Com relação às associações e às representações de proximidades entre os dois construtos, os resultados sugerem que os fatores de sucesso de carreira estejam orientados aos mesmos propósitos que os domínios motivacionais de valores individuais.

Valores de abertura à mudança, que representam o pensar e o agir de forma independente, estavam associados aos critérios de sucesso na carreira do quadrante intrapessoal-afeto, definido como os sentimentos e percepções do próprio indivíduo sobre a sua carreira.

Em oposição, valores de conservação, direcionados à obtenção da segurança e à manutenção do status quo, relacionaram-se com critérios do quadrante interpessoal-realização, definido pela trajetória factual de carreira socialmente validada. 
A autotranscendência, com motivadores de aceitação e cuidado com bem estar dos outros, correlacionou-se com critérios do quadrante interpessoal-afeto, voltado para os sentimentos e percepções do indivíduo em suas relações com outras pessoas e as instituições nas quais sua carreira se desenvolve.

Por fim, valores de autopromoção, que visam o sucesso individual e o domínio sobre os outros, estavam ligados aos critérios do quadrante intrapessoal-realização, conceituado como as conquistas factuais de carreira valorizadas pelo indivíduo.

Da mesma forma que a internalização dos valores ocorre ao longo do processo de socialização, outros conteúdos culturais, tais como crenças, atitudes e padrões da sociedade, também são esposados pelas pessoas como seus nesse mesmo processo (KUCZYNSKI; NAVARA, 2006).

A internalização de todos esses conteúdos é um produto da aprendizagem de quais formas de agir, de pensar ou de sentir são desejáveis, úteis e importantes para se obter sucesso no âmbito social em que se vive. No entanto, essa aprendizagem não é passiva, ocorrendo mediante a negociação entre as necessidades e os desejos individuais e as restrições e as oportunidades do ambiente.

Assim, por um lado, é possível que a seleção dos critérios de sucesso na carreira obedeça à mesma lógica das prioridades de domínios motivacionais de valores por advirem do aprendizado obtido no processo de socialização. Por outro, também é admissível que o sistema de valores individuais oriente a escolha dos critérios de sucesso pelos quais as pessoas julgam as consequências de suas carreiras.

Todavia, as técnicas e a metodologia de pesquisa adotadas não permitem afirmar por qual dos dois processos os fatores de sucesso na carreira e os domínios de valores individuais se interligam. Logo, futuras pesquisas podem se destinar à compreender a natureza dessa associação. 


\subsection{Implicações para a prática}

Hennequin (2007) indica que é essencial que as organizações facilitem o sentimento de sucesso na carreira de seus empregados. Esse sentimento pode resultar em atitudes e comportamentos no trabalho mais favoráveis à empresa. Dessa maneira, a autora afirma que o sucesso pessoal pode contribuir para o sucesso organizacional.

Peluchette (1993), por sua vez, ressalta que quando indivíduos não se sentem bem sucedidos dentro da corporação podem emergir sentimentos de alienação e de desengajamento, afetando negativamente os seus desempenhos profissionais.

Como observam Hall et al (2012), profissionais de diferentes áreas atribuem maior importância para distintos fatores de sucesso na carreira. Assim, as organizações precisam conhecer as necessidades e as motivações de seus empregados, estabelecendo, ainda, processos de planejamento de carreira que sincronizem as decisões dos empregados com os objetivos das organizações.

Uma vez compreendido o que significa ter sucesso na carreira para cada indivíduo ou grupo de pessoas, torna-se possível definir políticas e práticas de gestão que atendam às suas necessidades e fomentem seus sentimentos de êxito.

Hall et al (2012) indicam que indivíduos cujo significado de sucesso está baseado em reconhecimento têm maiores necessidades de receber feedbacks formal ou informalmente. Aqueles que priorizam equilíbrio na vida mas que não conseguem administrar adequadamente as demandas profissionais e pessoais precisam de auxílio para aprender a lidar com e a resolver as questões de equilíbrio. Por fim, pessoas que sentem necessidade de estabilidade e de segurança no emprego devem ter incentivos para aumentar seus níveis de empregabilidade por meio de programas de desenvolvimento de carreira, de habilidades e de redes de relacionamentos.

De acordo com os resultados deste estudo, uma outra forma de se obter informações sobre as preferências por determinadas consequências de carreira é conhecendo os valores esposados pelas pessoas. 
Choo et al (2009), dessa maneira, ressaltam que ao se compreender as prioridades dos sistemas de valores dos empregados, uma corporação pode formular melhores políticas de retenção, bem como atrair e selecionar pessoas que satisfar-se-ão com seu sistema de gestão e que, portanto, sentir-se-ão bem sucedidas.

De um ponto de vista do indivíduo, a ciência de seus valores pode ajudar a identificar se suas escolhas profissionais são úteis para alcançar o que ele entende como um fator de sucesso na carreira.

Isso torna-se ainda mais relevante porque o advento das novas carreiras oferece menos guias externos pelos quais as pessoas podem se orientar para verificar seu sucesso na carreira, restando somente a opção de olhar para dentro de si, sondando seus valores pessoais (HALL; MIRVIS, 1996; ARTHUR et al, 2005; HESLIN, 2005).

\subsection{Limitações do estudo e implicações para futuras pesquisas}

Em função das opções metodológicas do estudo, pode-se perceber algumas limitações de seus achados. Em primeiro lugar, a amostra não probabilística impossibilitou que as probabilidades fossem atribuídas às observações objetivamente e, portanto, inviabilizou que a confiabilidade dos resultados da amostra fossem determinados em termos de suas probabilidades (YAMANE, 1967).

Assim, generalizações das conclusões para a população total, a partir dos resultados da amostra, foram descartadas (KISH, 1995). O estudo abrangeu apenas um pequeno conjunto de profissionais brasileiros, principalmente paulistas, com alta escolaridade e renda, também impedindo generalizações para os trabalhadores brasileiros em geral e para populações de outros países.

Estudos indicam que os valores de crescimento e de defesa são mais contrastados em regiões ou em países mais desenvolvidos do que nos menos desenvolvidos (BILSKY et al, 2011; FISCHER et al, 2011) e também para pessoas cujas condições socioeconômicas permitem que a individualidade e a privacidade sejam asseguradas (FISCHER et al, 2011). Isso acentua a capacidade de diferenciação entre as polaridades do eixo crescimento versus defesa. 
Tal limitação demanda a replicação do estudo com outras populações para verificar a validade e a possibilidade de generalização de seus achados. Profissionais com características e experiências de trabalho diferentes, especialmente aqueles cujas condições de sobrevivência não estiveram asseguradas durante suas infância e adolescência, também perceberiam a oposição entre fatores de sucesso na carreira?

Em virtude da utilização de survey, no qual não houve a possibilidade de inclusão de novos critérios objetivos e subjetivos utilizados para avaliar sucesso na carreira pelos respondentes, foi inviável identificar a existência de outros critérios que sejam mais relevantes para a amostra em estudo.

Portanto, a sugestão de Arthur et al (1996) pela investigação de todas as interpretações possíveis que os atores trazem para as suas próprias situações de carreiras não foi atendida.

Além disto, Arthur et al (2005), Greenhaus (2003) e Heslin (2005) afirmam que o construto sucesso na carreira é multidimensional. Embora este estudo tenha encontrado duas dimensões bipolares que explicam a organização subjacente às percepções individuais sobre os fatores de sucesso na carreira, essas seriam suficientes para representar adequadamente todos os significados que o sucesso na carreira pode assumir?

Uma terceira limitação do estudo adveio de seu desenho transversal. Tal tipo de desenho impossibilitou a inferência de relações causais entre valores individuais e a escolha critérios de sucesso na carreira, bem como sobre a natureza temporal da interdependência entre sucesso objetivo e subjetivo na carreira.

Assim, o estudo não permitiu inferências causais sobre as relações entre os fatores de sucesso na carreira e os domínios de valores individuais, endereçando futuras pesquisas sobre a natureza dessa relação.

Pontuou-se duas possibilidades pelas quais os dois construtos se relacionem: (1) que os dois tenham a mesma natureza por terem sido aprendidos no processo de socialização; (2) que o sistema de valores individuais oriente a escolha dos critérios de sucesso pelos quais as pessoas julgam as consequências de suas carreiras. Qual dos dois processos seria o responsável por essa associação? Existe algum outro que possa explicá-la? 
Esta tese, assim, constituiu-se em um primeiro passo para a compreensão da estrutura dimensional dos fatores de sucesso na carreira e de sua associação com o sistema de valores individuais. No entanto, ainda existem muitas questões sem respostas e que merecem atenção de pesquisadores por sua relevância para as pessoas e para as organizações em um contexto de novas carreiras e de valores culturais que fomentam uma maior liberdade e autonomia dos indivíduos. 


\section{REFERÊNCIAS}

ABELE, Andrea E.; SPURK, Daniel. How do objective and subjective career success interrelate over time? Journal of Occupational and Organizational Psychology, v. 82, p. 803-824, 2009.

ANASTASI, Anne. Testes psicológicos. 2a ed. São Paulo: E.P.U, 1977.

ANASTASI, Anne; URBINA, Susana. Testagem psicológica. $7^{\text {a }}$ ed. Porto Alegre: ARTMED, 2000.

ANDERSON, David R. et al. Estatística aplicada à administração e economia. São Paulo: Cengale Learning, 2006.

ARNETT, Jeffrey J. Socialization in emerging adulthood. In: GRUSEC, Joan E.; HASTINGS, Paul D. Handbook of Socialization: Theory and Research. New York: The Guilford Press, 2007.

ARTHUR, Michael B. et al. The Handbook of Career Theory. Cambridge, UK: Cambridge University Press, 1989.

ARTHUR, Michael B. et al. Career success in a boundaryless career world. Journal of Organizational Behavior, v. 26, p. 177-202, 2005.

ARTHUR, Michael B.; ROUSSEAU, Denise M. The Boundaryless Career: A new employment principle for a new organizational era. New York, NY: Oxford University Press, 1996.

BAILYN, Lotte. Understanding individual experience at work: comments on the theory and practice of careers. In: ARTHUR, Michael B. et al. Handbook of Career Theory. New York: Cambridge University Press, 1989.

BARDI, Anat; GOODWIN, Robin. The dual route to value change: individual processes and cultural moderators. Journal of Cross-cultural Psychology, v. 42, n. 2, p. 271-287, 2011.

BARLEY, Stephen R. Careers, identities, and institutions: the legacy of the Chicago School of Sociology. In: ARTHUR, Michael B. et al. Handbook of Career Theory. New York: Cambridge University Press, 1989.

BELL, Daniel. The coming of post-industrial society. New York: Basic Books, 1973. 
BILSKY, Wolfgang et al. The structural organization of human values-evidence from three rounds of the European Social Survey (ESS). Journal of Cross-cultural Psychology, v. 42, n. 5, p. 759-776, 2011.

BILSKY, Wolfgang; SCHWARTZ, Shalom H. Values and personality. European Journal of Personality, n. 8, p. 163-181, 1994.

BOUDREAU, John W. et al. Effects of personality on executive career success in the U.S. and Europe. CAHRS Working Paper Series. Paper 111, 1999.

BROWN, Duane. The role of work and cultural values in occupational choice, satisfaction, and success: a theoretical statement. Journal of Counseling and Development, v. 80, n. 1, p. 48-56, 2002.

BURKE, Ronald J. Career success and personal failure: feelings among managers. Psychological Reports, v. 84, p. 651-653, 1999.

CENTRE FOR CROSSCULTURAL COMPARISONS. DraftManual_SVS_14Feb2009.doc. Disponível em: http://crossculturalcentre.homestead.com/Values.html. Acessado em: 22/04/2013.

CIECIUCH, Jan; SCHWARTZ, Shalom H. The number of distinct basic values and their structure assessed by PVQ-40. Journal of Personality Assessment, v. 94, n. 3, p. 321-328, 2012.

$\mathrm{CHOO}$, Soo Slew et al. Life values and job satisfaction: comparing local managers to the japanese and chinese expratriates in Singapore. International Journal of Business Studies, v. 17, n. 1, p. 61-106, 2009.

COSTA, Luciano V. A relação entre a percepção de sucesso na carreira e o comprometimento organizacional: um estudo entre professores de universidades privadas selecionadas da Grande São Paulo. São Paulo, 2010. Tese (Doutorado em Administração) Programa de Pós-graduação em Administração, Faculdade de Economia, Administração e Contabilidade da Universidade de São Paulo.

CRESWELL, John W. Research design: qualitative, quantitative, and mixed methods approaches. Thousand Oaks, CA: Sage, 2009.

CRONBACH, Lee J. Test validation. In: THORNDIKE, Robert L., Educational measurement. Washington, DC: American Council on Education, 1971.

CRONBACH, Lee J.; MEELH, Paul E. Construct validity in psychological tests. Psychological Bulletin, v. 52, p. 281-302, 1955. 
DANIS, Wade D. et al. Values and upward influence strategies in transition: evidence from the Czech Republic. Journal of Cross-cultural Psychology, v. 42, n. 2, p. 288-306, 2011.

DEMEL, Barbara et al. Career success around the world: its meaning and perceveid influences in 11 countries. In: BRISCOE, Jon P. et al. Careers Around the World. New York: Routledge, 2012.

DRIES, Nick. The meaning of career success: avoiding reification through a closer inspection of historical, cultural, and ideological contexts. Career Development International, v. 16, n. 4, p. 364-384, 2011.

DRIES, Nick et al. Career success: constructing a multidimensional model. Journal of Vocational Behavior, v. 73, p. 254-267, 2008.

DYKE, Lorraine S.; MURPHY, Steven A. How We Define Success: a qualitative study of what matters most to women and men. Sex Roles, v. 55, p. 357-371, 2006.

EBEL, Robert L. Must all tests be valid? American Psychologist, v. 16, p. 640-647, 1961.

EBY, Lillian T. et al. Predictors of success in the era of the bourndaryless career. Journal of Organizational Behavior, v. 24, n. 6, p. 689-708, 2003.

EDDLESTON, Kimberly A.; POWELL, Gary N. The role of gender identity in explaining sex diferences in business owners' career satisfier preferences. Journal of Business Venturing, v. 23, p. 244-256, 2008.

EGRI, Carolyn P.; RALSTON, David A. Generation cohorts and personal values: a comparison of China and the United States. Organization Science, v. 15, n. 2, p. 210-220, 2004.

FEATHER, N. T. Value importance, conservatism, and age. European Journal of Social Psychology, v. 7, n. 2, p. 241-245, 1977.

FISCHER, Ronald et al. Does social context affect value structures? Testing the withincountry stability of value structures with a functional theory of values. Journal of Crosscultural Psychology, v. 42, n. 2, p. 253-270, 2011.

FONTAINE, Johnny R. J. et al. Structural equivalence of the values domain across cultures: distinguishing sampling fluctuations from meaningful variation. Journal of Cross-cultural Psychology, v. 39, n. 4, p. 345-365, 2008.

FREITAS, Henrique et al. Dinâmica do processo de coleta e análise de dados via web. CIBRAPEQ - Congresso Internacional de Pesquisa Qualitativa, 24 a 27 de março, Taubaté/SP, 2004. 
FRIEDMAN, Stewart D.; GREENHAUS, Jeffrey H. Choosing work or Family... or both? In: Work and Family - Allies or enemies?: What happens when business professionals confront life choices. New York: Oxford University Press, 2000.

GATTIKER, Urs E.; LARWOOD, Laurie. Subjective career success: a study of managers and support personnel. Journal of Business and Psychology, v. 1., n. 2, p. 78-94, 1986.

GANDAL, Neil et al. Personal values priorities of economists. Human Relations, v. 58, n. 10, p. 1227-1252, 2005.

GIDDENS, Anthony. A constituição da sociedade. São Paulo: Martins Fontes, 2003.

GIL, Antonio C. Como elaborar projetos de pesquisa. São Paulo: Atlas, 2009.

GORGIEVSKI, Marjan J. et al. Small business owners'success criteria, a values approach to personal differences. Journal of Small Business Management, v. 49, n. 2, p. 207-232, 2011.

GREENHAUS, Jeffrey H. Career dynamics. In: BORMAN, Walter C. et al. Handbook of Psychology, vol. 12, Industrial and Organizational Psychology. New Jersey: John Wiley \& Sons, 2003.

GREENHAUS, Jeffrey $\mathrm{H}$. et al. Effects of race on organizational experiences, job performance evaluations, and career outcomes. Academy of Management Journal, v. 33, n. 1, p. 64-86, 1990.

GREENHAUS, Jeffrey H.; FOLEY, S. The intersection of work and family lives. In: GUNZ, Hugh; PEIPERL, Maury. Handbook of Career Studies. Thousand Oaks, CA: Sage, 2007.

GRUSEC, Joan E.; GOODNOW, Jacqueline J. Impact of parental discipline methods on the child's internalization of values: A reconceptualization of current points of view. Developmental Psychology, v. 30, n. 1, p. 4-19, 1994.

GUEST, David E.; STURGES, Jane. Living to work - working to live: conceptualizations of careers among contemporary workers. In: GUNZ, Hugh; PEIPERL, Maury. Handbook of Career Studies. Thousand Oaks, CA: Sage, 2007.

GUION, Robert M. Content validity in moderation. Personnel Psychology, v. 31, p. 205-213, 1978.

GÜNTHER, Hartmut. Como elaborar um questionário. In: PASQUALI, L. Instrumentos Psicológicos: Manual Prático de Elaboração. Brasília, DF: LabPAM - Laboratório de Pesquisa em Avaliação e Medida e IBAPP - Instituto Brasileiro de Avaliação e Pesquisa em Psicologia, 1999. 
GUNZ, Hugh P.; HESLIN, Peter A. Reconceptualizing career success. Journal of Organizational Behavior, v. 26, p. 105-111, 2005.

GUNZ, Hugh et al. Boundaries in the study of career. In: GUNZ, Hugh; PEIPERL, Maury. Handbook of Career Studies. Thousand Oaks, CA: Sage, 2007.

HAIR JR., Joseph F. et al. Análise multivariada de dados. Porto Alegre: Bookman, 2005.

HALL, Douglas T. The Career is Dead - Long Live the Career: a relational approach to careers. San Francisco, CA: Jossey-Bass, 1996.

HALL, Douglas T. Careers In and Out of Organizations. San Francisco, CA: Sage, 2002.

HALL, Douglas T.; CHANDLER, Dawn E. Psychological success: when the career is a calling. Journal of Organizational Behavior, v. 25, p. 1-22, 2004.

HALL, Douglas T.; MIRVIS, Philip H. Psychological success and the boundaryless career. In: ARTHUR, Michael B.; ROUSSEAU, Denise M. The Boudaryless Career: a new employment principle for a new organizational era. New York: Oxford, 1996.

HALL, Douglas T. et al. Implications for the management of people and organizations. In: BRISCOE, Jon P. et al. Careers Around the World. New York: Routledge, 2012.

HAY, Amanda; HODGKINSON, Myra. Exploring MBA career success. Career Development International, v. 11, n. 2, p. 108-124, 2006.

HENNEQUIN, Emilie. What "career success" means to blue-collar workers. Career Development International, v. 12, n. 6, p. 565-581, 2007.

HESLIN, Peter A. Conceptualizing and evaluating career success. Journal of Organizational Behavior, n. 26, p. 113-136, 2005.

HITLIN, Steven; PILIAVIN, Jane A. Values: reviving a dormant concept. Annual Review of Sociology, v. 30, p. 359-393, 2004.

HUBLEY, Anita M.; ZUMBO, Bruno D. A dialetic on validity: where we have been and where we are going. Journal of General Psychology, v. 123, n. 3, p. 207-215, 1996.

HUGHES, Everett C. Institutional office and the person. The American Journal of Sociology, v. 43, n. 3, p. 404-413, 1937.

HUGHES, Everett C. Men and their work. Glencloe, Illinois: The Free Press, 1958. 
HUGHES, Everett C. Careers. Qualitative Sociology, v. 20, n. 3, p. 389-397, 1997.

INGLEHART, Ronald; WELZEL, Christian. Modernization, cultural change and democracy: the human development sequence. Cambridge, UK: Cambridge University Press, 2005.

JUDGE, Timothy A.; KAMMEYER-MUELLER, John D. Personality and career success. In: GUNZ, Hugh; PEIPERL, Maury. Handbook of Career Studies. Thousand Oaks, CA: Sage, 2007.

KANTER, Rosabeth M. Careers and the wealth of nations: a macro-perspective on the structure and implications of career forms. In: ARTHUR, Michael B. et al. Handbook of Career Theory. New York: Cambridge University Press, 1989.

KHAPOVA, Svetlana N. et al. The subjective career in the knowledge economy. In: GUNZ, Hugh; PEIPERL, Maury. Handbook of Career Studies. Thousand Oaks, CA: Sage, 2007.

KISH, Leslie. Survey Sampling. New York: Wiley-Interscience, 1995.

KNAFO, Ariel; SCHWARTZ, Shalom H. Identity formation and parent-child value congruence in adolescence. The British Journal of Developmental Psychology, v. 22, p. 439-458, 2004.

KLUCKHOHN, Clyde. Values and value-orientations in the theory of action: an exploration in definition and classification. In: PARSONS, Talcott; SHILS, Edward A. (Eds.). Toward a General Theory of Action. Massachusetts: Cambridge, 1951.

KORMAN, Abraham K. et al. Career success and personal failure: alienation in professional and managers. Academy of Management Journal, v. 24, n. 2, p. 342-260, 1981.

KRUSKAL, Joseph B. Multidimensional scaling by optimizin goodness-of-fit to a non-metric hypothesis. Psychometrika, v. 29, p. 1-27, 1964.

KUCZYNSKI, Leon; NAVARA, Geoff S. Sources of innovation and change in socialization, internalization and acculturation. In: KILLEN, Melanie; SMETANA, Judith G. Handbook of Moral Development. New Jersey: Lawrence Earlbaum Associates, 2006.

LEE, Mary Dean et al. Exploring career and personal outcomes and the meaning of career success among part-time professionals in organizations. In: BURKE, Ronald J. Research Companion to Work Hours and Work Addiction. Cheltenham, UK: Edward Elgar, 2006. 
LONDON, Manuel; STUMPF, Stephen A. A individual and organizational career development in changing times. In: HALL, Douglas T. Career Development in Organizations. San Francisco, CA: Jossey-Bass, 1986.

LUCAS, Kristen; BUZZANEL, Patrice M. Blue-collar work, career, and success: occupational narratives of Sisu. Journal of Applied Communicational Research, v. 32, n. 4, p. 273-292, 2004.

MAINIERO, Lisa A.; SULLIVAN, Sherry E. The Opt-out Revolt: Why people are leaving companies to create kaleidoscope careers. Mountain View, CA: Davies-Black Publishing, 2006.

MASSEY, Douglas S. A brief history of human society: the origin and role of emotion in social life. American Sociological Review, v. 67, p. 1-29, 2002.

MAYER, Karl U. Whose lives? How history, societies, and institutions define and shape life couses. Research in Human Development, v. 1, n. 3, p. 161-187, 2004.

MAYRHOFER, Wolfgang et al. Contextual issues in the study of careers. In: GUNZ, Hugh; PEIPERL, Maury. Handbook of Career Studies. Thousand Oaks, CA: Sage Publications, 2007.

MAYRHOFER, Wolfgang et al. The 5C Project: harvesting lessons for future career research. In: BRISCOE, Jon P. et al. Careers Around the World. New York: Routledge, 2012.

MEGLINO, Bruce M.; RAVLIN, Elizabeth C. Individual values in organizations: concepts, controversies, and research. Journal of Management, v. 24, n. 3, p. 351-389, 1998.

MILES, Raymond E.; SNOW, Charles C. Twenty-first-century careers. In: ARTHUR, Michael B.; ROUSSEAU, Denise M. The Boundaryless Career: A new employment principle for a new organizational era. New York, NY: Oxford University Press, 1996.

MIRVIS, Philip H.; HALL, Douglas T. New organizational forms and the new career. In: HALL, Douglas T. The Career is Dead - Long Live the Career: A relational approach to careers. San Francisco, CA: Jossey-Bass, 1996.

MOORE, Celia et al. Tracing the historical roots of career theory. In: GUNZ, Hugh; PEIPERL, Maury. Handbook of Career Studies. Thousand Oaks, CA: Sage Publications, 2007.

NABI, Ghulam R. The relationship between HRM, social support and subjective career success among men and women. International Journal of Manpower, v. 22, n. 5, p. 457474, 2001. 
NG; Thomas W. H. et al. Predictors of objective and subjective career success: a metaanalysis. Personnel Psychology, v. 58, p. 367-408, 2005.

NICHOLSON, Nigel; DE WAAL-ANDREWS, Wendy. Playing to win: biological imperatives, self-regulation, and trade-offs in the game of career success. Journal of Organizational Behavior, n. 26, p. 137-154, 2005.

ORPEN, Christopher. The relationship between managerial success and personal values in South Africa: a research note. Journal of Management Studies, v. 13, n. 2, p. 196-198, 1976.

PARKER, Barbara; CHUSMIR, Leonard H. Motivation needs and their relationship to life success. Human Relations, v. 44, n. 12, p. 1301-1312, 1991.

PARKS, Laura; GUAY, Russell P. Personality, values, and motivation. Personality and Individual Differences, v. 47, p. 675-684, 2009.

PASQUALI, Luiz. Psicometria: teoria e aplicações. Brasília: Editora Universidade de Brasília, 1998.

PASQUALI, Luiz. Instrumentos psicológicos: manual prático de elaboração. Brasília: LabPAM e IBAPP, 1999.

PASQUALI, Luiz. Análise fatorial para pesquisadores. Brasília: LabPAM, 2000.

PASQUALI, Luiz. Psicometria: teoria dos testes na psicologia e na educação. Brasília: LabPAM e CESPE, 2002.

PASQUALI, Luiz. Instrumentação psicológica: fundamentos e práticas. São Paulo: Artmed, 2010.

PATTON, Wendy. Changing career: the role of values. In: COLLIN, Audrey; YOUNG, Richard A. The Future of Career. Cambridge, UK: Cambridge University Press, 2000.

PELUCHETTE, Joy Van Eck. Subjective career success: the influence of individual diferences, Family, and organizational variables. Journal of Vocational Behavior, v. 43, p. 198-208, 1993.

PORTO, Juliana B. Estrutura e Transmissão dos Valores Laborais: um estudo com estudantes universitários. Brasília, DF, 2004. Tese (Doutorado em Psicologia). Instituto de Psicologia da Universidade de Brasília.

PRINCE-GIBSON, Eetta; SCHWARTZ, Shalom H. Value priorities and gender. Social Psychology Quarterly, v. 61, n. 1, p. 49-67, 1998. 
ROCCAS, Sonia et al. The big five personality and personal values. Personality and Social Psychology Bulletin, n. 28, v. 6, p. 789-801, 2002.

ROHAN, Meg J. A rose by any name? The values construct. Personality and Social Psychology Review, n. 4, v. 3, p. 255-277, 2000.

ROKEACH, Milton. Understanding Human Values: Individual and social. London: The Free Press, 1979.

SAGIV, Lilach. Vocational interests and basic values. Journal of Career Assessment, v. 10, n. 2, p. 233-257, 2002.

SAMPIERI, Roberto H. et al. Metodología de la investigación. México: McGraw-Hill, 2006.

SAVICKAS, Mark L. Renovating the psychology of careers for the twenty-first century. In: COLLIN, Audrey; YOUNG, Richard A. The Future of Career. Cambridge, UK: Cambridge University Press, 2000.

SAVICKAS, Mark L. Occupational choice. In: GUNZ, Hugh; PEIPERL, Maury. Handbook of Career Studies. Thousand Oaks, CA: Sage Publications, 2007.

SCALABRIN, Ana Carla et al. Tendências na gestão de carreira. In: DUTRA, Joel S. (Org.). Gestão de Carreiras na Empresa Contemporânea. São Paulo: Atlas, 2010.

SCHWARTZ; Shalom H. Are there universal aspects in the structure and content of human values? Journal of Social Issues, v. 50, n. 4, p. 19-45, 1994.

SCHWARTZ; Shalom H. Validade e aplicabilidade da teoria de valores. In: TAMAYO, Alvaro; PORTO, Juliana B. (Org.). Valores e Comportamento nas Organizações. Petrópolis, RJ: Vozes, 2005.

SCHWARTZ, Shalom H. Cultural and individual value correlates of capitalism: a comparative analysis. Psychological Inquiry, v. 18, n. 1, p. 52-57, 2007.

SCHWARTZ; Shalom H. Studying values: personal adventure, future directions. Journal of Cross-cultural Psychology, v. 42, n. 2, p. 307-319, 2011.

SCHWARTZ, Shalom H.; BARDI, Anat. Influences of adaptation to communist rule on value priorities in Eastern Europe. Political Psychology, v. 18, n. 2, p. 385-410, 1997. 
SCHWARTZ, Shalom H.; BILSKY, Wolfgang. Toward a universal psychological structure of human values. Journal of Personality and Social Psychology, v. 53, n. 3, p. 550-562, 1987.

SCHWARTZ, Shalom H.; BILSKY, Wolfgang. Toward a theory of the universal content and structure of values: extension and cross-cultural replications. Journal of Personality and Social Psychology, v. 58, n. 5, p. 878-891, 1990.

SCHWARTZ; Shalom H. et al. Extending the cross-cultural validity of the theory of basic human values with a different method of measurement. Journal of Cross-cultural Psychology, v. 32, n. 5, p. 519-542, 2001.

SCHWARTZ; Shalom H. et al. Les valeurs de base de la personne: théorie, mesures et applications. Revue Française de Sociologie, v. 47, n. 4, p. 929-968, 2006.

SCHWARTZ, Shalom H.; SAGIE, Galit. Value consensus and importance: a cross-national study. Journal of Cross-cultural Psychology, v. 31, n. 4, p. 465-497, 2000.

SEIBERT, Scott E. et al. What do proactive people do? A longitudinal model linking proactive personality and career success. Personnel Psychology, v. 54, n. 4, p. 845-874, 2001.

SELLTIZ, Claire et al. Métodos de pesquisa nas relações sociais. São Paulo: EPU - Editora da Universidade de São Paulo, 1975.

SIEGEL, Sidney; CASTELLAN JR., N. John. Estatística não-paramétrica para ciências do comportamento. $2^{\mathrm{a}}$ ed. Porto Alegre: Artmed, 2006.

STEINMETZ, Holger et al. Testing measurement invariance using multigroup CFA: differences between educational groups in human values measurement. Quality Quantity, v. 43, n. 4, p. 599-616, 2009.

STOREY, John A. 'Fracture lines' in the career environment. In: COLLIN, Audrey; YOUNG, Richard A. The Future of Career. Cambridge, UK: Cambridge University Press, 2000.

STRUCH, Naomi et al. Meaning of basic values for women and men: a cross-cultural analysis. Personality and Social Psychology Bulletin, v. 28, n. 1, p. 16-28, 2002.

STURGES, Jane. What it means to succeed: personal conceptions of career success held by male and female managers at different ages. British Journal of Management, v. 10, p. 239252, 1999. 
SULLIVAN, Sherry E. The changing nature of careers: a review and research agenda. Journal of Management, v. 25, n. 3, p. 457-484, 1999.

SULLIVAN, Sherry E.; BARUCH, Yehuda. Advances in career theory and research: $a$ critical review and agenda for future exploration. Journal of Management, v. 35, n. 6, p. 1542-1571, 2009.

TABACHNICK, Barbara G.; FIDELL, Linda S. Using multivariate statistics. Needham Heights, MA: Allyn \& Bacon, 2007.

TAMAYO, Alvaro. Hierarquia de valores transculturais e brasileiros. Psicologia: Teoria e Pesquisa, v. 23, p. 7-15, 2007.

TAMAYO, Alvaro et al. Diferenças nas prioridades axiológicas de músicos e advogados. Psicologia: Reflexão e Crítica, v. 11, n. 2, p. 281-293, 1998.

UNITE, Julie et al. Careers and age: career success for older and younger workers. In: BRISCOE, Jon P. et al. Careers Around the World. New York: Routledge, 2012.

VALCOUR, Monique et al. Customized careers. In: GUNZ, Hugh; PEIPERL, Maury. Handbook of Career Studies. Thousand Oaks, CA: Sage Publications, 2007.

VASCONCELLOS, Liliana; GUEDES, Luiz F. A. E-surveys: Vantagens e limitações dos questionários eletrônicos via internet no contexto da pesquisa científica. In: X SEMEAD Seminários em Administração da FEA-USP, 2007.

VERGARA, Sylvia C. Projetos e relatórios de pesquisa em administração. São Paulo: Atlas, 2009a.

VERGARA, Sylvia C. Métodos de coleta de dados no campo. São Paulo: Atlas, 2009b.

WEICK, Karl E.; BERLINGER, Lisa. R. Career improvisation in self-designing organizations. In: ARTHUR, Michael B. et al. Handbook of Career Theory. New York: Cambridge University Press, 1989.

WILKINSON Leland. Multidimensional scaling. In: SYSTAT 10. Statistics II. Chicago: SPSS Inc., 2000.

WRZESNIEWSKI, Amy. "It's not just a job": shifting meanings of work in the Wake of 9/11. Journal of Management Inquiry, v.11, n. 3, p. 230-234, 2002.

YAMANE, Taro. Elementary Sampling Theory. London, UK: Prentice-Hall, 1967. 


\begin{abstract}
ANEXOS
ANEXO 1 -E-mail convite para participação nas duas pesquisas sobre sucesso na carreira.

ANEXO 2 - Apresentação do survey para a validação do inventário de critérios de sucesso na carreira.

ANEXO 3 - Instruções de preenchimento do survey para a validação do inventário de critérios de sucesso na carreira.

ANEXO 4 - Questionário sócio-demográfico da pesquisa para validação do inventário de critérios de sucesso na carreira.

ANEXO 5 - Apresentação do survey para a verificação da associação entre sucesso na carreira e valores individuais.

ANEXO 6-Schwartz Values Survey.

ANEXO 7 - Questionário sócio-demográfico para a verificação da associação entre sucesso
\end{abstract} na carreira e valores individuais. 
ANEXO 1 - E-mail convite para participação nas duas pesquisas sobre sucesso na carreira.

Olá,

Meu nome é Betina e sou Doutoranda do Programa de Pós-graduação em Administração da Faculdade de Economia e Administração da Universidade de São Paulo (FEA/USP). Minha orientadora é a Prof.a Dra Tania Casado e minha tese de doutoramento é sobre Sucesso na Carreira e Valores Individuais.

Agradeço muito se puderem dispor de alguns minutos de seu tempo para preencher o questionário da pesquisa. O tempo aproximado para responder ao questionário é de 20 minutos.

O questionário pode ser acessado através do seguinte link:

https://www.research.net/s/Sucesso

Todos os dados obtidos serão tratados coletivamente e de maneira sigilosa, não havendo identificação individual nem exposição do conteúdo das respostas pessoais.

Sua participação é de extrema importância para nossa pesquisa!

Se desejar receber os resultados da pesquisa, basta deixar seu e-mail registrado no campo que aparecerá ao final do questionário. Um resumo executivo será enviado para você, logo após a defesa da Tese. Estimo que isso ocorrerá até julho.

Caso tenha interesse em saber mais sobre os objetivos do trabalho, por favor me contate pelo endereço eletrônico betina.miranda@usp.br - será um grande prazer explicá-los.

Agradeço imensamente pela atenção e conto com a sua participação.

Obrigada!

Betina Miranda 
ANEXO 2 - Apresentação do survey para a validação do inventário de critérios de sucesso na carreira.

Olá,

Você está participando de uma pesquisa sobre Sucesso na Carreira e Valores Individuais.

Esta pesquisa é parte integrante do projeto de tese de Doutorado em administração da FEA-USP da aluna Betina Silvestri Miranda, orientada pela Profa. Dra. Tania Casado.

A seguir, serão apresentadas as instruçẽes para o preenchimento deste questionário. Leia-as com atenção, lembrando que não existem respostas certas ou erradas. $O$ preenchimento deve levar de 20 a 30 minutos.

Sua participação é voluntária. Nenhum dado individual será publicado.

Qualquer dúvida, você poderá me contactar pelo e-mail: betina.miranda@usp.br.

Muito obrigada!

Betina Miranda 
ANEXO 3 - Instruções de preenchimento do survey para a validação do inventário de critérios de sucesso na carreira.

\section{INSTRUÇÕES}

Neste questionário você deve perguntar a si próprio: "O que é ter sucesso na carreira PARA MIM, como objetivos de carreira que eu busco em MINHA VIDA?".

Avalie o quão importante cada critério de sucesso é para você como um objetivo de carreira em sua vida usando a escala abaixo:

Como objetivo de carreira em minha vida, esse critério de sucesso na carreira é:

-1. Oposto aos meus critérios

0 e 1. Não importante

2, 3 e 4. Importante

5 e 6 . Muito importante

7. De suprema importância

Quanto maior o número $(-1,0,1,2,3,4,5,6,7)$, mais importante é o critério de sucesso como um objetivo de carreira em sua vida.

Existem duas listas de critérios de sucesso na carreira a seguir.

Antes de começar, leia os critérios de sucesso na carreira da primeira lista, ESCOLHA AQUELE QUE É O MAIS IMPORTANTE para você o e avalie como de suprema importância (7).

A seguir, identifique O(S) CRITÉRIO(S) OPOSTO(S) AOS SEUS e avalie-os como -1 (oposto aos meus critérios). Se não houver nenhum critério desse tipo, escolha o critério menos importante para você e avalie-o como 0 .

Depois, avalie os demais critérios de sucesso na carreira, tentando diferenciar, tanto quanto possível, os critérios de sucesso entre si. PROCURE USAR TODOS OS NÚMEROS. Você poderá repetir os números em suas respostas/avaliações. Após concluir a avaliação dos critérios apresentados na primeira lista, repita o mesmo procedimento considerando os critérios apresentados na segunda lista. 
ANEXO 4 - Questionário sócio-demográfico da pesquisa para validação do inventário de critérios de sucesso na carreira.

\section{INFORMAÇÕES PESSOAIS}

*3. Em que cidade, estado e país você reside atualmente?

Cidade

Estado

Pais

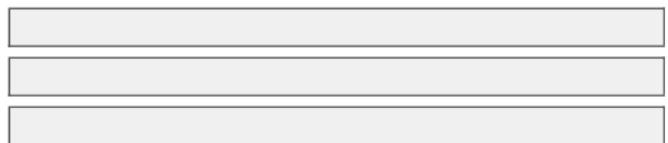

*4. Em que cidade, estado e país você viveu mais tempo até completar 15 anos? Cidade

Estado

Pais

*5. Em que ano você nasceu?

*6. Gênero:

Masculino

Feminino

*7. Desde que ano está no mercado de trabalho? (Considere estágio, trabalho voluntário ou informal e emprego formal).

8. Qual o número total de promoções que você já recebeu ao longo de toda sua carreira? (Promoções são quaisquer aumentos de remuneração, de nível e/ou aumentos significativos de responsabilidade ou ampliação do escopo de trabalho).

9. Você já teve um ou mais períodos significativos de interrupção em sua carreira?

Não

$\bigcirc \operatorname{sim}$ 
* 10. Qual é a sua ocupação ou que tipo de cargo você ocupa na empresa em que trabalha? (Leia atentamente as descrições abaixo e escolha aquele que mais se aproxima do perfil do seu cargo ou ocupação atual).

Presidente/Diretor = Atuação estratégica: abrange toda a organização.

Gerente = Atuação tática: abrange um departamento ou uma área.

Supervisor/Coordenador $=$ Atuação operacional: abrange uma operação ou um projeto.

Especialista/Analista/Administrativo = Outros profissionais da empresa, sem responsabilidade de chefia, cujos cargos exijam ensino superior completo ou em andamento.

Técnico/Operacional $=$ Outros profissionais da empresa, sem responsabilidade de chefia, cujos cargos exijam até o ensino médio ou ensino médio profissionalizante.

Trainee = Participante de um programa para recém-formados que tem o objetivo de acelerar o desenvolvimento profissional para assumir um cargo gerencial.

Estagiário = Estudante do ensino médio ou do ensino superior que tenha firmado um Termo de Compromisso de Estágio com a empresa e sua instituição de ensino.

Autônomo ou profissional liberal = Profissional que trabalha por conta própria, em regime de contrato temporário e/ou sem vínculo empregatício com uma organização (prestador de serviços, representante comercial, profissional liberal ou consultor).

Empresário/empreendedor $=$ Proprietário de um empreendimento ou sócio-proprietário de uma organização.

Não trabalho atualmente.

11. Em qual setor trabalha atualmente?
Privado
Público ou Governamental
Sem fins lucrativos ou ONG

12. Você tem responsabilidades de gestão ou supervisão?

Não

Sim. Você é responsável por quantas pessoas?

13. Desde que ano você tem esta ocupação ou ocupa este cargo?

14. Em média, quantas horas você trabalha por semana?

* 15. Qual é o seu nível de escolaridade atual? (Considere o mais alto já concluído).

Ensino Fundamental

Ensino Médio

Curso Superior de Curta Duração

Curso Superior de Tecnologia (Tecnólogo)

Curso Superior (Bacharelado, Licenciatura ou Habilitação)

Pós-Graduação Lato Sensu (MBA, Aperfeiçoamento ou Especialização)

Mestrado

Doutorado 
16. Qual é a área do seu curso de graduação? (Considere aquela com a qual mais se identifica).

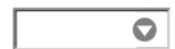

Outra (especifique)

17. Este curso de graduação foi concluído

no ano de:

na Instituição de Ensino

Superior (nome da IES):

18. Qual é a área do seu curso de pós-graduação de maior grau (Lato Sensu, Mestrado ou Doutorado)?

$\nabla$

Outra (especifique)

19. Em que ano concluiu o curso de pós-graduação de maior grau (Lato Sensu, Mestrado e/ou Doutorado)?

no ano de:

na Instituição de Ensino

Superior (nome da IES):

* 20. Qual a sua faixa de renda bruta mensal individual? (Não considere a renda de outros membros de sua família).

Até $R \$ 610,00$

Entre $R \$ 611,00$ e $R \$ 1.220,00$

Entre $R \$ 1.221,0$ e $R \$ 1.830,00$

Entre $R \$ 1.831,00$ e $R \$ 3.050,00$

Entre $R \$ 3.051,00$ e $R \$ 4.880,00$

Entre $R \$ 4.881,00$ e $R \$ 9.150,00$

Entre R\$ $9.151,00$ e R\$ $12.810,00$

Acima de R\$12.810,00

*21. Qual o seu estado civil?

Solteiro(a)

Casado(a)/ Vive com companheiro(a)

Separado(a)/ Divorciado(a)

Viúvo(a)

Outro (especifique) 
22. Se você respondeu que é casado(a) ou vive com companheiro(a), seu cônjuge participa do mercado de trabalho atualmente?

Não $\bigcirc \operatorname{sim}$

*23. Você tem filhos?

Não

Sim. Quantos?

24. Qual a idade do filho mais novo? (Caso não tenha filhos, deixe esta questão em branco).

25. Você se considera:
Amarelo
Branco
Índio
Mulato
Negro
Pardo
Outro 
*26. Você se interessa em receber um relatório sobre esta pesquisa?

Não

$\bigcirc \operatorname{sim}$

27. E-mail:

28. No espaço abaixo você pode deixar seus comentários sobre o questionário.



Agradecemos sua participação!

Betina Miranda

Profa. Dra. Tania Casado 
ANEXO 5 - Apresentação do survey para a verificação da associação entre sucesso na carreira e valores individuais.

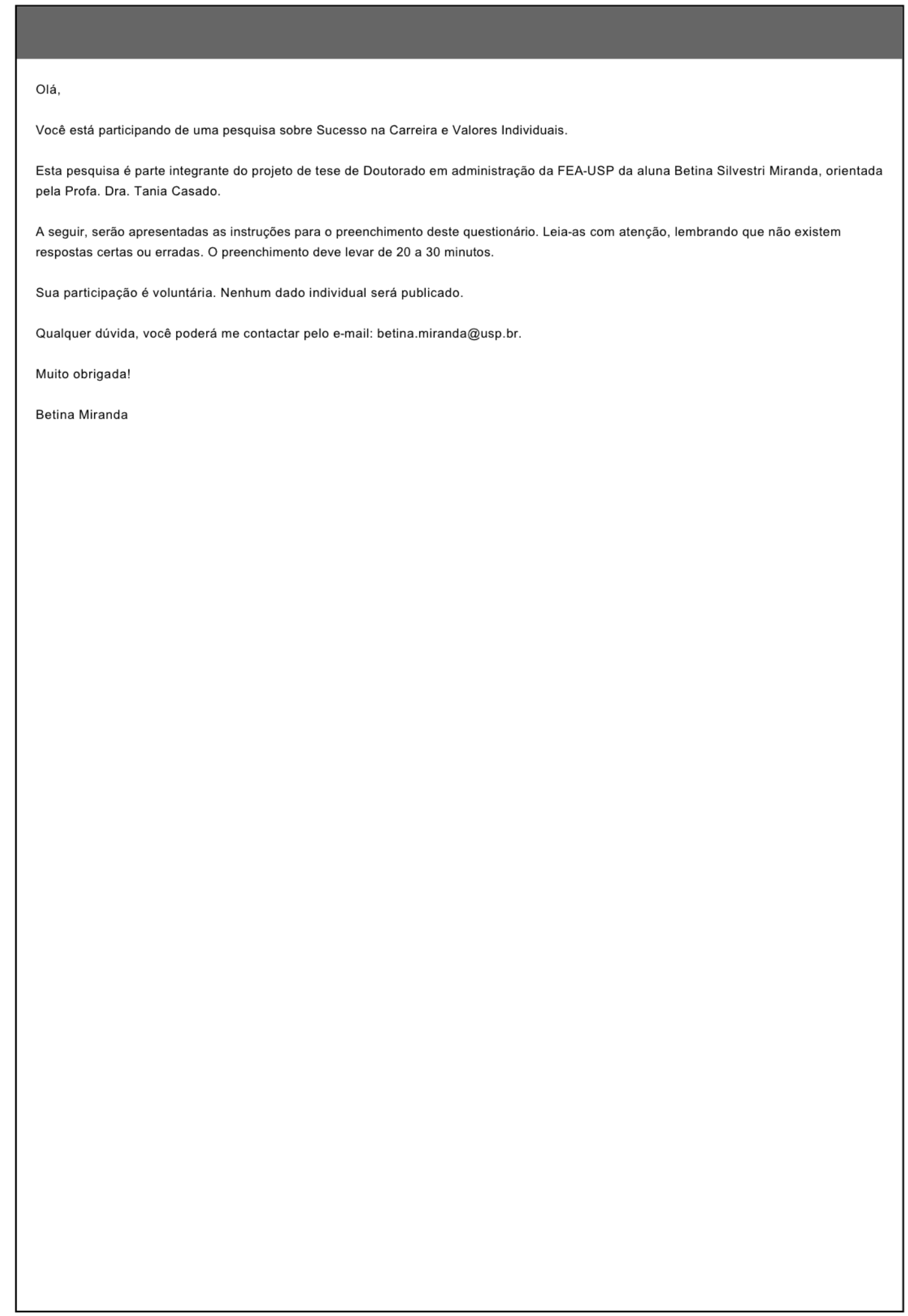


ANEXO 6 - Schwartz Values Survey.

\section{QUESTIONÁRIO DE VALORES - INSTRUÇÕES}

Neste questionário você deve perguntar a si próprio: "Que valores são importantes PARA MIM, como princípios orientadores em MINHA VIDA e que valores são menos importantes PARA MIM?" Há duas listas de valores nas páginas seguintes. Esses valores vêm de diferentes culturas. Entre os parênteses que se seguem a cada valor, encontra-se uma explicação que pode ajuda-lo(a) a compreender seu significado.

Sua tarefa é avaliar quão importante cada valor é para você como um princípio orientador em sua vida. Use a escala de avaliação abaixo: COMO PRINCIPIO ORIENTADOR EM MINHA VIDA, esse valor é:

-1. Oposto aos meus princípios

0 e 1. Não importante

2, 3 e 4. Importante

5 e 6 . Muito importante

7. De suprema importância

Quanto maior o número $(0,1,2,3,4,5,6)$, mais importante é o valor como um princípio orientador em sua vida.

Além dos números de 0 a 6 , em suas avaliações você pode usar ainda, os números -1 e 7 , considerando que:

-1 - significa que o valor é oposto aos princípios que orientam sua vida.

7 - significa que o valor é de suprema importância como um princípio orientador em sua vida; geralmente, uma pessoa não possui mais de dois desses valores.

Existem duas listas de valores a seguir.

Antes de começar, leia os valores da primeira lista, ESCOLHA AQUELE QUE É O MAIS IMPORTANTE para você o e avalie como de suprema importância (7).

A seguir, identifique O(S) VALORES(S) OPOSTO(S) AOS SEUS e avalie-os como -1 (oposto aos meus valores). Se não houver nenhum valor desse tipo, escolha o valor menos importante para você e avalie-o como 0 .

Depois, avalie os demais valores, tentando diferenciar, tanto quanto possivel, os valores entre si. PROCURE USAR TODOS OS NÚMEROS. Você poderá repetir os números em suas respostas/avaliações. Após concluir a avaliação dos valores apresentados na primeira lista, repita o mesmo procedimento considerando os valores apresentados na segunda lista. 
*2. Que valores são importantes PARA MIM, como princípios orientadores em MINHA VIDA, e que valores são menos importantes PARA MIM?

(Lembre-se de escolher primeiro o valor que é de suma importância para você e avalialo como 7; em seguida escolha o(s) valor(es) que é(são) oposto(s) a seus princípios e o (s) avalie como -1 ou o(s) que não é(são) importante(s) e o(s) avalie como 0 ou 1; por fim, avalie os demais valores de acordo com sua importância).

\begin{tabular}{|c|c|}
\hline 01. IGUALDADE (oportunidades iguais para todos) & $\boldsymbol{\theta}$ \\
\hline 02. HARMONIA INTERIOR (em paz comigo mesmo) & $\boldsymbol{\theta}$ \\
\hline 03. PODER SOCIAL (controle sobre os outros, domínio) & $\theta$ \\
\hline 04. PRAZER (satisfação de desejos) & ○ \\
\hline 05. LIBERDADE (liberdade de ação e pensamento) & $\boldsymbol{\theta}$ \\
\hline 06. UMA VIDA ESPIRITUAL (ênfase em assuntos espirituais) & ( \\
\hline 07. SENSO DE PERTENCER (sentimento de que os outros se importam comigo) & $\boldsymbol{\theta}$ \\
\hline 08. ORDEM SOCIAL (estabilidade da sociedade) & $\boldsymbol{\theta}$ \\
\hline 09. UMA VIDA EXCITANTE (experiências estimulantes) & $\theta$ \\
\hline 10. SENTIDO DA VIDA (um propósito na vida) & ( \\
\hline 11. POLIDEZ (cortesia, boas maneiras) & $\boldsymbol{\theta}$ \\
\hline 12. RIQUEZAS (posses materiais, dinheiro) & $\theta$ \\
\hline 13. SEGURANÇA NACIONAL (proteção da minha nação contra inimigos) & $\theta$ \\
\hline 14. AUTO-RESPEITO (crença em meu próprio valor) & 8 \\
\hline 15. RETRIBUIÇÃO DE FAVORES (quitação de débitos) & $\boldsymbol{\theta}$ \\
\hline 16. CRIATIVIDADE (unicidade, imaginação) & $\theta$ \\
\hline 17. UM MUNDO EM PAZ (livre de guerras e conflitos) & $\boldsymbol{\theta}$ \\
\hline 18. RESPEITO PELA TRADIÇÃO (preservação de costumes vigentes há longo tempo) & $\theta$ \\
\hline 19. AMOR MADURO (profunda intimidade emocional e espiritual) & $\boldsymbol{\theta}$ \\
\hline 20. AUTO-DISCIPLINA (auto-restrição, resistência à tentação) & ( \\
\hline 21. PRIVACIDADE (o direito de ter um espaço pessoal) & $\theta$ \\
\hline 22. SEGURANÇA FAMILIAR (proteção para minha familia) & $\boldsymbol{\theta}$ \\
\hline 23. RECONHECIMENTO SOCIAL (respeito, aprovação pelos outros) & $\boldsymbol{\theta}$ \\
\hline 24. UNIÃO COM A NATUREZA (integração com a natureza) & $\boldsymbol{\theta}$ \\
\hline 25. UMA VIDA VARIADA (cheia de desejos, novidades e mudanças) & ( \\
\hline 26. SABEDORIA (compreensão madura da vida) & ( \\
\hline 27. AUTORIDADE (direito de liderar ou de mandar) & ( \\
\hline 28. AMIZADE VERDADEIRA (amigos próximos e apoiadores) & $\boldsymbol{\theta}$ \\
\hline 29. UM MUNDO DE BELEZA (esplendor da natureza e das artes) & $\theta$ \\
\hline 30. JUSTIÇA SOCIAL (correção da injustiça, cuidado para com os mais fracos) & $\boldsymbol{\nabla}$ \\
\hline
\end{tabular}


*3. Que valores são importantes PARA MIM, como princípios orientadores em MINHA VIDA, e que valores são menos importantes PARA MIM?

(Lembre-se de escolher primeiro o valor que é de suma importância para você e avalialo como 7; em seguida escolha o(s) valor(es) que é(são) oposto(s) a seus princípios e o (s) avalie como -1 ou o(s) que não é(são) importante(s) e o(s) avalie como 0 ou 1; por fim, avalie os demais valores de acordo com sua importância).

\begin{tabular}{|c|c|}
\hline 31. INDEPENDENTE (ser auto-suficiente e auto-confiante) & $\boldsymbol{\nabla}$ \\
\hline 32. MODERADO (evitar sentimentos e ações extremadas) & $\boldsymbol{\theta}$ \\
\hline 33. LEAL (ser fiel aos amigos e grupos) & $\boldsymbol{\theta}$ \\
\hline 34. AMBICIOSO (trabalhar arduamente, ter aspirações) & ( \\
\hline 35. ABERTO (ser tolerante a diferentes idéias e crenças) & $\boldsymbol{\theta}$ \\
\hline 36. HUMILDE (ser modesto, não me autopromover) & $\boldsymbol{\nabla}$ \\
\hline 37. AUDACIOSO (procurar a aventura, o risco) & ( \\
\hline 38. PROTETOR DO AMBIENTE (preservar a natureza) & $\boldsymbol{\theta}$ \\
\hline 39. INFLUENTE (exercer impacto sobre as pessoas e eventos) & 8 \\
\hline 40. RESPEITOSO PARA COM OS PAIS E IDOSOS (reverenciar pessoas mais velhas) & ( \\
\hline 41. AUTO-DETERMINADO (escolher meus próprios objetivos) & $\boldsymbol{\theta}$ \\
\hline 42. SAUDÁVEL (gozar de boa saúde física e mental) & $\boldsymbol{\nabla}$ \\
\hline 43. CAPAZ (ser competente, eficaz, eficiente) & ( \\
\hline 44. CIENTE DOS MEUS LIMITES (submeter-me às circunstâncias da vida) & $\boldsymbol{\theta}$ \\
\hline 45. HONESTO (ser sincero, autêntico) & $\boldsymbol{\theta}$ \\
\hline 46. PRESERVADOR DA MINHA IMAGEM PÚBLICA (proteger minha reputação) & $\boldsymbol{\theta}$ \\
\hline 47. OBEDIENTE (cumprir meus deveres e obrigações) & $\boldsymbol{\nabla}$ \\
\hline 48. INTELIGENTE (ser lógico, racional) & $\boldsymbol{\theta}$ \\
\hline 49. PRESTATIVO (trabalhar para o bem-estar de outros) & $\boldsymbol{\nabla}$ \\
\hline 50. QUE GOZA A VIDA (gostar de comer, sexo, lazer, etc.) & $\boldsymbol{\theta}$ \\
\hline 51. DEVOTO (apegar-me fortemente à fé religiosa) & $\boldsymbol{\nabla}$ \\
\hline 52. RESPONSÁVEL (ser fidedigno, confiável) & $\boldsymbol{\nabla}$ \\
\hline 53. CURIOSO (ter interesse por tudo, espirito exploratório) & $\boldsymbol{\nabla}$ \\
\hline 54. INDULGENTE (estar pronto a perdoar os outros) & $\boldsymbol{\theta}$ \\
\hline 55. BEM SUCEDIDO (atingir os meus objetivos) & $\boldsymbol{\theta}$ \\
\hline 56. LIMPO (ser asseado, arrumado) & $\boldsymbol{\theta}$ \\
\hline 57. AUTO-INDULGÊNCIA (fazer coisas prazerosas) & D \\
\hline
\end{tabular}


ANEXO 7 - Questionário sócio-demográfico para a verificação da associação entre sucesso na carreira e valores individuais.

\section{INFORMAÇÕES PESSOAIS}

*4. Em país você reside atualmente?

Brasil

Outro pais (especifique)

5. Se você reside no Brasil, em qual estado?

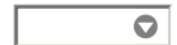

*6. Em que país você viveu mais tempo até completar 15 anos?

Brasil

Outro pais (especifique)

7. Se você viveu mais tempo até compretar 15 anos no Brasil, em qual estado?

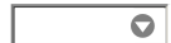

* 8. Em que ano você nasceu?

$\nabla$

*9. Gênero:

Masculino $\bigcirc$ Feminino

* 10. Desde que ano você está no mercado de trabalho? (Considere estágio, trabalho voluntário ou informal e emprego formal).

$\nabla$

11. Qual o número total de promoções que você já recebeu ao longo de toda sua carreira? (Promoções são quaisquer aumentos de remuneração, de nível e/ou aumentos significativos de responsabilidade ou ampliação do escopo de trabalho). $\checkmark$ 
* 12. Qual é a sua ocupação ou que tipo de cargo você ocupa na empresa em que trabalha? (Leia atentamente as descrições abaixo e escolha aquele que mais se aproxima do perfil do seu cargo ou ocupação atual).

Presidente/Diretor $=$ Atuação estratégica: abrange toda a organização.

Gerente = Atuação tática: abrange um departamento ou uma área.

Supervisor/Coordenador $=$ Atuação operacional: abrange uma operação ou um projeto.

Especialista/Analista/Administrativo = Outros profissionais da empresa, sem responsabilidade de chefia, cujos cargos exijam ensino superior completo ou em andamento.

Técnico/Operacional $=$ Outros profissionais da empresa, sem responsabilidade de chefia, cujos cargos exijam até o ensino médio ou ensino médio profissionalizante.

Trainee = Participante de um programa para recém-formados que tem o objetivo de acelerar o desenvolvimento profissional para assumir um cargo gerencial.

Estagiário = Estudante do ensino médio ou do ensino superior que tenha firmado um Termo de Compromisso de Estágio com a empresa e sua instituição de ensino.

Autônomo ou profissional liberal $=$ Profissional que trabalha por conta própria, em regime de contrato temporário e/ou sem vínculo empregatício com uma organização (prestador de serviços, representante comercial, profissional liberal ou consultor).

Empresário/empreendedor $=$ Proprietário de um empreendimento ou sócio-proprietário de uma organização.

Aposentado.

Não trabalho atualmente.

\section{Em qual setor trabalha atualmente?}
Privado
Público ou Governamental
Sem fins lucrativos ou ONG

\section{*14. Desde que ano você tem esta ocupação ou ocupa este cargo? $\nabla$}

* 15. Em média, quantas horas você trabalha por semana?
Até 10 horas
De 51 a 60 horas
De 11 a 20 horas
De 61 a 70 horas
De 21 a 30 horas
De 71 a 80 horas
De 31 a 40 horas
De 81 a 90 horas
De 41 a 50 horas
Mais de 90 horas

16. Você faz algum trabalho voluntário atualmente?

Não

Sim 
*17. Qual é o seu nível de escolaridade atual? (Considere o mais alto já concluído).

Ensino Fundamental

Ensino Médio

Curso Superior

Pós-Graduação Lato Sensu (MBA, Aperfeiçoamento ou Especialização)

Mestrado

Doutorado

* 18. Qual é a área do seu curso de graduação? (É permitido marcar mais de uma, no entanto, marque apenas as concluídas).

$\begin{array}{ll}\square \text { Administração } & \square \text { Ciências da computação } \\ \square \text { Astronomia e Fisica } & \square \text { Ciências da saúde } \\ \square \text { Matemática e estatistica } & \square \text { Ciências humanas } \\ \square \text { Ciências agrárias } & \square \text { Cireito } \\ \square \text { Ciências biológicas } & \square \text { Economia social } \\ \square \text { Ciências contábeis } & \\ \text { Outra (especifique) } & \end{array}$

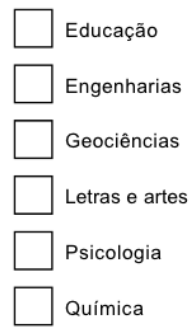

* 19. Qual a sua faixa de renda bruta mensal individual? (Não considere a renda de outros membros de sua família).

Até $R \$ 1.356,00$

Entre $R \$ 1.356,01$ e $R \$ 2.034,00$

Entre $R \$ 2.034,01$ e $R \$ 3.390,00$

Entre $\mathrm{R} \$ 3.390,01$ e $\mathrm{R} \$ 5.424,00$

Entre $R \$ 5.424,01$ e $R \$ 10.170,00$

Entre $R \$ 10.170,01$ e $R \$ 14.238,00$

Entre $R \$ 14.238,01$ e $R \$ 20.340,00$

Entre $R \$ 20.340,01$ e $R \$ 30.510,00$

Acima de $\mathrm{R} \$ 30.510,00$

*20. Qual o seu estado civil?

Solteiro(a)

Casado(a)/ Vive com companheiro(a)/ União estável

Separado(a)/ Divorciado(a)

$\bigcirc$ Viúvo(a)

Outro (especifique) 
21. Se você respondeu que é casado(a) ou vive com companheiro(a), seu cônjuge participa do mercado de trabalho atualmente?

Não

$\bigcirc \operatorname{sim}$

*22. Você tem filhos?

Não

Sim. Quantos?

23. Qual a idade do filho mais novo? (Caso não tenha filhos, deixe esta questão em branco).




*24. Você se interessa em receber um relatório sobre esta pesquisa?

Não

$\bigcirc \operatorname{sim}$

25. E-mail:

26. No espaço abaixo você pode deixar seus comentários sobre o questionário.

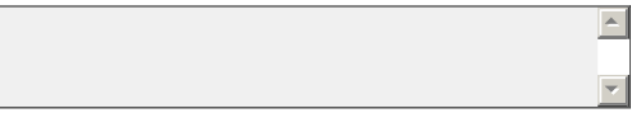

Agradecemos sua participação!

Betina Miranda

Profa. Dra. Tania Casado 